\title{
Arbeidsmarktmonitor Metalektro 2013
}

Citation for published version (APA):

Gerards, R., de Grip, A., de Hoon, M. L. A., Künn-Nelen, A. C., \& van Thor, J. A. F. (2014).

Arbeidsmarktmonitor Metalektro 2013. ROA. ROA Reports No. 004

https://doi.org/10.26481/umarep.2014004

Document status and date:

Published: 01/01/2014

DOI:

10.26481/umarep.2014004

Document Version:

Publisher's PDF, also known as Version of record

\section{Please check the document version of this publication:}

- A submitted manuscript is the version of the article upon submission and before peer-review. There can be important differences between the submitted version and the official published version of record.

People interested in the research are advised to contact the author for the final version of the publication, or visit the DOI to the publisher's website.

- The final author version and the galley proof are versions of the publication after peer review.

- The final published version features the final layout of the paper including the volume, issue and page numbers.

Link to publication

\footnotetext{
General rights rights.

- You may freely distribute the URL identifying the publication in the public portal. please follow below link for the End User Agreement:

www.umlib.nl/taverne-license

Take down policy

If you believe that this document breaches copyright please contact us at:

repository@maastrichtuniversity.nl

providing details and we will investigate your claim.
}

Copyright and moral rights for the publications made accessible in the public portal are retained by the authors and/or other copyright owners and it is a condition of accessing publications that users recognise and abide by the legal requirements associated with these

- Users may download and print one copy of any publication from the public portal for the purpose of private study or research.

- You may not further distribute the material or use it for any profit-making activity or commercial gain

If the publication is distributed under the terms of Article $25 \mathrm{fa}$ of the Dutch Copyright Act, indicated by the "Taverne" license above, 


\section{ARBEIDSMARKTMONITOR METALEKTRO 2013}

ROA-R-2014/4

Ruud Gerards

Andries de Grip

Marloes de Hoon

Annemarie Künn-Nelen

Jesper van Thor 


\section{Colofon}

(C) Researchcentrum voor Onderwijs en Arbeidsmarkt (ROA). Niets uit deze uitgave mag op enige manier worden verveelvoudigd zonder voorafgaande schriftelijke toestemming van de directeur van het ROA.

\section{Researchcentrum voor Onderwijs en Arbeidsmarkt}

School of Business and Economics

Maastricht University

\section{Vormgeving}

ROA secretariaat, Maastricht

\section{Verkoop}

Researchcentrum voor Onderwijs en Arbeidsmarkt email: secretary-roa-sbe@maastrichtuniversity.nl

website: www.roa.nl

ISBN: 978-90-5321-526-5 


\section{INHOUD}

Voorwoord

Management summary vii

01 Dynamiek in de metalektro 11

1.1 Ontwikkelingen in de Metalektro 2013

1.2 Ontwikkeling van werkgelegenheid in de Metalektro 1996-2012 14

$\begin{array}{ll}1.3 \text { Vergrijzing in de Metalektro } & 15\end{array}$

1.4 Opleidingsniveau in de Metalektro 16

$\begin{array}{ll}1.5 \text { Innovatie } & 18\end{array}$

02 Arbeidsmarktontwikkelingen metalektro $2013 \quad 19$

2.1 Percentage bedrijven met instroom was in 2013 hoger dan in $2012 \quad 20$

2.2 Percentage bedrijven met uitstroom was in 2013 lager dan in $2012 \quad 21$

2.3 Werkgelegenheidsontwikkeling verschilt sterk per functie 23

2.4 Forse toename flexibele schil in eerste helft $2013 \quad 25$

2.5 Ontwikkeling van de flexibele schil naar functiecategorie 26

03 Vacatures en werving $\quad 29$

3.1 Meer bedrijven met vacatures en vacatures sneller ingevuld 30

3.2 Vacatures voornamelijk gevolg van toename in hoeveelheid werk 31

3.3 Externe bureaus nog altijd meest effectieve wervingskanalen 33

3.4 Minder bedrijven met wervingsproblemen in $2013 \quad 35$

3.5 Voornaamste oorzaken en gevolgen van wervingsproblemen
weinig veranderd

3.6 Aanpassingen om moeilijk vervulbare vacatures op te vullen 40

04 Competenties en opleidingsinspanningen 45

4.1 Opleidingsbestedingen gestabiliseerd 46

4.2 Initiatief voor trainingen en stimuleren van betrokkenheid personeel $\quad 48$

4.3 Meeste trainingen vaktechnisch of BHV/EHBO 50

4.4 Tijd en geld nog altijd meest genoemde belemmeringen voor
scholing/training

4.5 HR-instrumenten die in 2013 zijn ingezet $\quad 54$ 
05 Technologische innovaties en organisatorische veranderingen

5.1 Toename verwacht in product-, proces- en dienstinnovaties

5.2 Organisatorische innovaties

5.3 Aan de grote behoefte aan breed inzetbare uitvoerende technici wordt vrijwel altijd voldaan

5.4 De komende vijf jaar meer samenwerking verwacht tussen metalektrobedrijven en hogescholen/universiteiten

06 Pensionering: Verwachtingen en uitdagingen

6.1 Vergrijzing in de Metalektro nog altijd hoger dan gemiddelde van alle sectoren in Nederland

6.2 Minder vervangingsproblemen verwacht

6.3 Duurzame inzetbaarheid

6.4 Aanpak vervangingsproblemen

07 Metalektro in de toekomst

7.1 Licht positieve werkgelegenheidsontwikkelingen verwacht tot midden 2014

7.2 Knelpunten verwacht in de personeelsvoorziening tot 2018

7.3 Technische functies zullen meer allround worden en gedragsmatige competenties worden belangrijker

7.4 Bevorderen van inzetbaarheid is voor een ruime meerderheid van bedrijven een speerpunt

7.5 Verwachte knelpunten bij de realisatie van speerpunten hebben voornamelijk betrekking op personeel

o8 Agenda voor de toekomst

8.1 Achtergrond

8.2 Door de bank genomen positieve ontwikkelingen in 2013

8.3 Positieve verwachtingen voor diverse indicatoren tekenen gestegen vertrouwen

8.4 Vergrijzing en verwachte vervangingsproblemen

8.5 Concluderend: positieve tekenen maar scherpte op knelpunten blijft geboden 


\section{VOORWOORD}

Met genoegen bieden de auteurs van het Researchcentrum voor Onderwijs en Arbeidsmarkt (ROA) en opdrachtgever Stichting $\mathrm{A}+\mathrm{O}$ Metalektro u de Arbeidsmarktmonitor Metalektro 2013 aan. De monitor bevat analyses van de actuele en toekomstige ontwikkelingen op personeels- en arbeidsmarktgebied in de Nederlandse Metalektro. De uitkomsten van deze analyses kunnen als input dienen bij het ontwikkelen van personeels- en arbeidsmarktbeleid door metalektrobedrijven, de sociale partners en andere partijen.

De rapportage die voor u ligt vormt het sluitstuk van een onderzoek waarbij gedurende een heel jaar op verschillende momenten gegevens zijn verzameld. De hoofdmoot van de bevindingen in de Arbeidsmarktmonitor Metalektro is gebaseerd op de uitgebreide internetvragenlijst die in 2013 aan het begin van ieder kwartaal door het werkgeverspanel is ingevuld. In elke meting zijn vragen beantwoord met betrekking tot de in- en uitstroom en vacatures. Hierop is de werkgelegenheidsbarometer gebaseerd. Een aantal centrale thema's is verdeeld over de vier vragenlijsten:

- werving en selectie,

- inzetbaarheid en doorstroom van personeel,

- sociale en technologische innovatie en scholing,

- competenties van het technisch personeel.

Om dieper te kunnen ingaan op de achtergronden van de bevindingen uit de vragenlijsten is ook een aantal metalektrobedrijven geïnterviewd. Daarnaast is gebruik gemaakt van gegevens afkomstig van het CBS, PME en de arbeidsmarktprognoses van het ROA.'

Wij willen op deze plaats alle bedrijven die de vragenlijsten hebben ingevuld bedanken voor hun bijdrage aan de monitor en hopen dat het rapport en de bedrijfsscan die zij ontvangen hen waardevolle benchmarkinformatie oplevert. Een speciaal woord van dank is daarbij gericht aan de bedrijven die bereid waren om deel te nemen aan de verdiepende gesprekken. De regiecommissie, bestaande uit Mabri Fennema en Henry de Groot (Stichting A+O Metalektro), Willie Berentsen en Rien Smit (FME-CWM) en Peter Niehoff (FNV Bondgenoten), wordt hartelijk bedankt voor hun constructieve feedback en de wijze waarop ze het onderzoek hebben begeleid. Het veldwerk, de dataverzame-

1 ROA (2013), De Arbeidsmarkt naar Opleiding en Beroep tot 2018, ROA-R-2013/11, Maastricht: ROA. 
ling- en verwerking voor deze monitor zijn verricht door Sander Dijksman (ROA). Tot slot bedanken wij, voor hun jarenlange constructieve input en prettige samenwerking Henry de Groot en Willie Berentsen, die in 2013 hun rollen in de regiecommissie overdroegen aan respectievelijk Mabri Fennema en Rien Smit. 


\section{MANAGEMENT SUMMARY}

Een van de meest positieve ontwikkelingen in 2013 is dat de omzetgroei in de Metalektro is toegenomen en in de tweede helft van het jaar zelfs weer positief was. In het kielzog van de omzet ging het dan ook de goede kant op met diverse andere indicatoren. $\mathrm{Er}$ werden minder productiebelemmeringen ervaren als gevolg van achterblijvende vraag, de verwachtingen over zowel product-, proces- als diensteninnovaties zijn toegenomen en er waren vanaf de tweede helft van het jaar weer meer metalektrobedrijven die een toename van de werkgelegenheid in hun bedrijf verwachtten dan bedrijven die krimp verwachtten (zie Hoofdstuk 1). Verder blijkt dat de flexibele schil is gegroeid en een aanzienlijk groter deel van het totale personeelsbestand in de Metalektro is gaan vormen, waardoor bedrijven snel kunnen inspelen op schommelingen in de omzet.

Toch is nog lang niet alles rozengeur en maneschijn. Per saldo was 2013 nog een jaar waarin er meer bedrijven waren die met een krimpende werkgelegenheid kampten dan bedrijven met groei, hoewel dit vrijwel volledig op het conto van de eerste helft van het jaar komt. In de tweede helft van het jaar hadden bedrijven met een groeiende werkgelegenheid weer een zeer klein overwicht (Hoofdstuk 2). Ten slotte is de gemiddelde leeftijd in de sector verder gestegen, waarmee de aandacht voor de vergrijzing van het personeel en de vervangingsvraag onverminderd actueel blijft.

\section{Werving van personeel}

In 2013 waren er in de Metalektro voor de meeste functiecategorieën meer bedrijven met vacatures. De meeste van deze vacatures zijn ontstaan door een toename van de hoeveelheid werk. Ondanks de toename van het aantal vacatures hadden bedrijven minder langdurig openstaande vacatures of wervingsproblemen. Als dat al het geval was dan kwam het vooral doordat sollicitanten niet de juiste competenties hadden of onvoldoende werkervaring, al waren er ook bedrijven die aangaven dat er voor bepaalde vacatures te weinig sollicitanten waren. Wervingsproblemen werden te lijf gegaan met een keuze uit beproefde strategieën, zoals het bieden van goede loopbaanperspectieven, het inschakelen van externe bureaus, het aantrekken van mensen met minder ervaring, flexibele inzet van huidige medewerkers, overwerk, om/bijscholing en een andere organisatie van het werk. Over het algemeen werden de traditioneel populaire en effectieve wervingskanalen (uitzendbureaus, werving- en selectiebureaus) ook in 2013 weer het best beoordeeld. Daarnaast beleefde de effectiviteit van het internet als 
wervingskanaal een bescheiden opleving. Hoofdstuk 3 gaat uitgebreid in op het thema werving.

\section{Opleidingsinspanningen, competenties en speerpunten toekomstig personeelsbeleid}

In 2013 werd door metalektrobedrijven gemiddeld een even groot deel van de loonsom $(1,3 \%)$ uitgegeven aan opleiding en training als in 2012. Dat deze uitgaven zijn gestabiliseerd betekent dat ze, voor het eerst sinds 2009, niet zijn gedaald. Uitgedrukt in dagen, volgde een gemiddelde technische medewerker in de Metalektro in 2013 2,5 dag aan cursussen en trainingen. Een belangrijke conclusie is dat technici in het MKB relatief even vaak vaktechnische trainingen volgden als technici die bij grote bedrijven werkzaam waren. Verder blijkt dat in 2013 de trainingsdeelname van technici met een tijdelijk contract alsook van technici die ingeleend werden is toegenomen. Bedrijven verwachten in de toekomst een stijging in onder meer trainingen en opleidingen gericht op leidinggeven, veilig gedrag en communicatieve en commerciële vaardigheden (zie Hoofdstuk 4). De verwachte stijging van de training in deze soft skills is een logisch gevolg van een aantal ontwikkelingen die bedrijven verwachten. Een meerderheid van metalektrobedrijven geeft aan dat technische functies meer allround worden en dat gedragsmatige competenties belangrijker zullen worden in de toekomst. Daarbij gaat het vooral om de PROFI competenties: Probleemoplossend vermogen, Relatie met klanten, Omgaan met veranderingen, Flexibiliteit en Initiatief. Geheel in lijn hiermee is de bevinding dat zeven op de tien bedrijven de inzetbaarheid van hun personeel verder willen bevorderen, wat daarmee het voornaamste speerpunt is van het toekomstig personeelsbeleid (Hoofdstuk 7).

\section{Vervangingsproblematiek en duurzame inzetbaarheid}

Het percentage oudere werknemers in de Metalektro is de afgelopen jaren gestaag toegenomen. Gezien de leeftijdsopbouw van het huidige personeelsbestand zal dit nog verder stijgen en zal de groep die de komende jaren met pensioen gaat groter worden. Bedrijven verwachten in vergelijking tot voorgaande jaren echter een afname van de pensioenuitstroom. Het is niet ondenkbaar dat bedrijven het aantal werknemers dat de komende jaren met pensioen zal gaan - en de daarmee gepaard gaande vervangingsproblemen - onderschatten. Om de verwachte vervangingsproblemen door pensionering te ondervangen nemen bedrijven echter wel een reeks maatregelen. De meest populaire maatregel is het aantrekken van nieuwe werknemers, zowel goed opgeleide krachten als werknemers die vervolgens intern worden opgeleid. Ook brede inzetbaarheid van de huidige werknemers moet voor een groot deel van de bedrijven de problemen als gevolg van pensioneringen inperken. Daarnaast werd het intensiveren van de relaties met het onderwijsveld in de afgelopen jaren door een toenemend aantal bedrijven gezien als een manier waarop vervangingsproblemen kunnen worden verminderd. Om duurzame inzetbaarheid te bevorderen bieden bedrijven hun medewerkers onder meer opleidingsmogelijkheden en worden oudere werknemers ontlast; bijvoorbeeld door hen werkzaamheden te laten verrichten waarbij de kennisoverdracht 
aan jongere werknemers centraal staat. Hoofdstuk 6 gaat uitgebreid in op de vergrijzing in de sector.

\section{Technologische innovaties en organisatorische veranderingen}

Evenals in 2012 heeft ook in 2013 weer ongeveer 85\% van alle metalektrobedrijven één of meerdere technologische vernieuwingen doorgevoerd. Bedrijven verwachten de komende jaren op alle vlakken van product, proces tot dienst nog meer te innoveren. Daarnaast heeft iets meer dan de helft van de bedrijven in 2013 een organisatorische verandering doorgevoerd. Het ging hier meestal om het variabel inzetten van technisch personeel. Ongeveer drie kwart van de bedrijven geeft aan behoefte te hebben aan breed inzetbare uitvoerende technici, voornamelijk om schommelingen in de bedrijfsdrukte op te vangen en ter vervanging van afwezig personeel. Aan deze behoefte werd in 2013 in vrijwel alle bedrijven voldaan. De komende jaren worden nog meer organisatorische veranderingen verwacht, waaronder een sterke toename in de samenwerking met onderwijsinstellingen. Hoofdstuk 5 gaat hier uitvoerig op in.

\section{Agenda voor de Toekomst}

Voor de komende jaren hebben metalektrobedrijven optimistische verwachtingen voor de werkgelegenheidsontwikkeling en flinke ambities op het terrein van innovatie en het aangaan van samenwerkingsverbanden. Dit is niet verrassend gezien de positieve ontwikkeling van de omzet, de omvang van de flexibele schil en het aantal bedrijven met vacatures in 2013. Bij het realiseren van deze ambities en verwachtingen kunnen bedrijven terugvallen op de HR strategieën die in de afgelopen jaren zijn ingezet. De bedrijven hoeven op HR gebied dus niet het wiel opnieuw uit te vinden, maar men moet scherp blijven op de bekende knelpunten, die de komende jaren onverminderd actueel blijven. Belangrijk knelpunt blijft de voortschrijdende vergrijzing van het personeelsbestand van veel bedrijven en het daaraan gerelateerde vervangingsvraagstuk. Metalektrobedrijven verwachten over het algemeen geen grote vervangingsproblemen. Wanneer de arbeidsmarktuitstroom vanwege pensionering over enkele jaren in een versnelling raakt en op dat moment de economie weer beter draait, dan zullen de vervangingsproblemen echter groot zijn. Het aantal moeilijk vervulbare vacatures zal dan weer toenemen. Veel bedrijven proberen de gevolgen van moeilijk vervulbare vacatures te ondervangen door hun personeel te laten overwerken. Op de lange termijn is dit niet zonder gevaar voor de duurzame inzetbaarheid van medewerkers. Het blijft daarom voor de bedrijven van groot belang om de ontwikkelingen op de arbeidsmarkt te blijven volgen en eventuele tekenen van toenemende krapte voor bepaalde functies meteen in een lange-termijn perspectief te plaatsen. Daarbij zullen de bedrijven de aandacht voor de toekomstige vervangingsvraag goed vast dienen te houden en zullen ze nog scherper moeten zijn op de mogelijke gevolgen van moeilijk vervulbare vacatures voor de duurzame inzetbaarheid van hun medewerkers. 



\section{1 \\ DYNAMIEK \\ IN DE METALEKTRO}

Een van de meest positieve ontwikkelingen in 2013 is dat de omzetgroei in de Metalektro is toegenomen en in de tweede helft van het jaar zelfs weer positief was. In het kielzog van de omzet ging het dan ook de goede kant op met diverse andere indicatoren. Er werden minder productiebelemmeringen ervaren als gevolg van achterblijvende vraag, de verwachtingen over zowel product-, proces- als diensteninnovaties zijn toegenomen en er waren vanaf de tweede helft van het jaar weer meer metalektrobedrijven die een toename van de werkgelegenheid in hun bedrijf verwachtten dan bedrijven die krimp verwachtten. Toch is nog lang niet alles rozengeur en maneschijn. Per saldo was 2013 nog een jaar waarin er meer bedrijven waren die met een krimpende werkgelegenheid kampten dan bedrijven met groei, hoewel dit vrijwel volledig op het conto van de eerste helft van het jaar komt. In de tweede helft van het jaar hadden bedrijven met een groeiende werkgelegenheid weer een zeer klein overwicht. Ten slotte is de gemiddelde leeftijd in de sector verder gestegen, waarmee de aandacht voor de vergrijzing van het personeel onverminderd actueel blijft. 


\subsection{Ontwikkelingen in de Metalektro 2013}

2013 was een jaar waarin de Nederlandse Metalektro op een aantal belangrijke vlakken herstel kende. Onder meer ten aanzien van de omzet en de gerealiseerde werkgelegenheidsontwikkeling konden in (de loop van) 2013 weer zwarte cijfers genoteerd worden. Deze positieve ontwikkeling in de sector als geheel geldt natuurlijk nog niet voor ieder individueel bedrijf.

Het (prille) herstel wat in 2013 plaats vond wordt allereerst getoond in Figuur 1.1. Deze figuur toont drie indicatoren van conjunctuurontwikkeling in de sector sinds 2006. In deze figuur markeert april 2013 zich duidelijk als het kantelpunt waarop alle drie de variabelen van richting veranderen. Twee variabelen veranderen van richting op een wijze die als ondubbelzinnig positief geïnterpreteerd moet worden. Het percentage bedrijven dat geen productiebelemmeringen kent neemt vanaf dan toe en het percentage bedrijven dat onvoldoende vraag voor haar producten kent neemt af. Op hetzelfde moment zien we een lichte toename in het percentage bedrijven dat belemmeringen kent als gevolg van personeelstekort. Waarschijnlijk als direct gevolg van de weer aantrekkende vraag die ertoe leidde dat minder bedrijven 'onvoldoende vraag' als probleem opgeven - heeft een licht stijgend deel van de bedrijven weer te maken met belemmerende personeelstekorten. Vooralsnog betreft dit nog geen $7 \%$ van de bedrijven, maar de onmiddellijke stijging in dit percentage bedrijven met personeelstekorten is bij dit nog prille herstel in vraag wellicht een kleine waarschuwing voor wat de sector aan mogelijke tekorten kan ervaren mocht economisch herstel zich in de volle breedte doorzetten.

FIGUUR 1.1 Conjunctuurontwikkeling Metalektro, 2006-2013 (CBS)

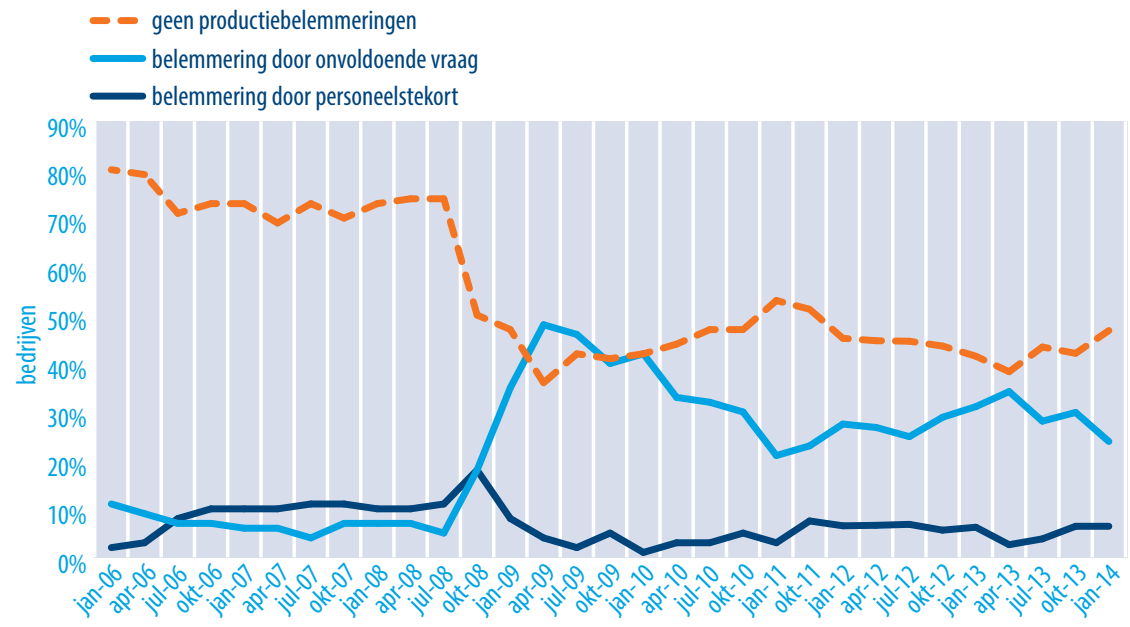

Bronnen: 2003 - jan 2011: CBS, Conjunctuurtest Industrie (SBI '93: 27) en voor okt 2011- jan 2014:

CBS, Conjunctuurenquête Nederland (SBI '08: 24-30, 33) 
Eén van de meest duidelijke indicatoren die het prille herstel in de sector weerspiegelt is de omzet. De ontwikkeling hiervan tussen 2007 en 2013 wordt getoond in Figuur 1.2. Al sinds de tweede helft van 2012 werd de omzetgroei steeds iets minder negatief en in het derde kwartaal van 2013 werd voor het eerst weer positieve groei genoteerd. De stijgende lijn zette door in het vierde kwartaal.

FIGUUR 1.2 Omzetontwikkeling Metalektro 2007-2013, \% groei ten opzichte van 1 jaar eerder

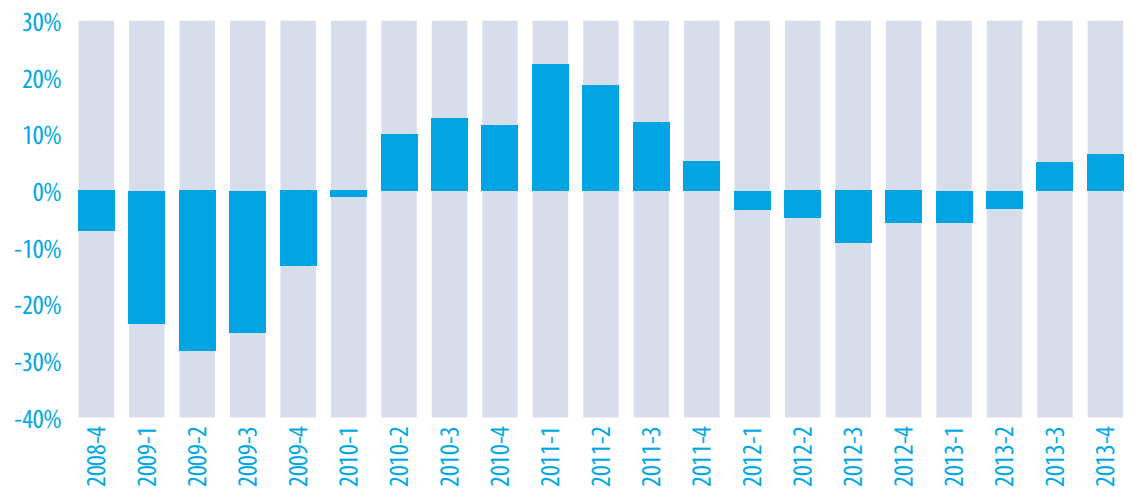

Bron: CBS, Nijverheidsstatistiek, 2007-2013

De personeelsontwikkeling en werkgelegenheidsverwachtingen van de bedrijven die deelnemen aan de arbeidsmarktmonitor houden gelijke tred met de omzetontwikkeling. Dit toont Figuur 1.3. Deze figuur toont allereerst de omzetgroei uit Figuur 1.2, maar dan als oranje lijn. Daarnaast toont Figuur 1.3 een indicator die laat zien of er in het voorgaande kwartaal per saldo meer bedrijven waren die de werkgelegenheid in hun bedrijf zagen toe- of afnemen. Dit wordt in de figuur weergegeven door de blauwe balkjes. Positieve waardes van de indicator duiden er op dat er in het afgelopen kwartaal meer metalektrobedrijven waren waar de werkgelegenheid is toegenomen dan is afgenomen. Negatieve waardes van de indicator wijzen er op dat er meer bedrijven waren die moesten snijden in hun personeelsbestand dan bedrijven die in personeelsaantal groeiden. De blauwe lijn laat zien of bedrijven overwegend positief of negatief zijn over de verwachte werkgelegenheidsontwikkelingen in hun bedrijf in het komende kwartaal. 
FIGUUR 1.3 Index personeelsontwikkeling en werkgelegenheidsverwachting, 2009-2012

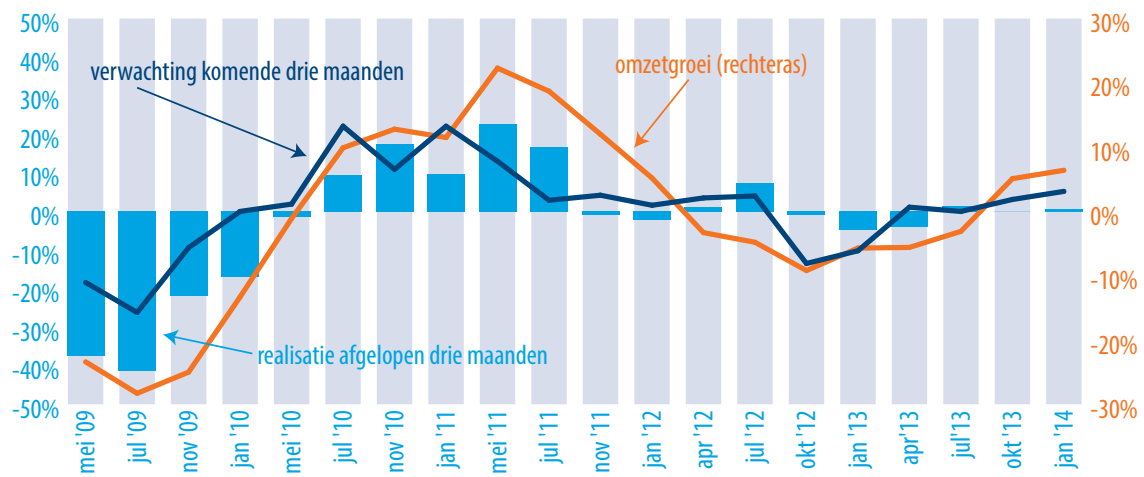

Bron: ROA, Arbeidsmarktmonitor Metalektro 2009-2013

Duidelijk is te zien dat alle drie de indicatoren globaal dezelfde trend volgen. Op het moment dat de omzetgroei de opgaande lijn weer heeft gevonden (oktober 2012) zien we eveneens de verwachtingen omtrent werkgelegenheid weer stijgen. De realisaties volgen daarna met een kwartaal vertraging hetzelfde patroon. De realisaties laten zien dat vanaf de tweede helft van 2013 de werkgelegenheidsontwikkeling bij meer bedrijven positief dan negatief is. De meest recente verwachtingen laten nog altijd een opgaande lijn zien dus voor de eerste helft van 2014 zijn licht positieve werkgelegenheidsrealisaties te verwachten, dat wil zeggen meer bedrijven waar werkgelegenheid groeit dan bedrijven waar deze krimpt. Desalniettemin is de opleving in de tweede helft van 2013 niet sterk genoeg om de daling in werkgelegenheid uit de eerste helft van het jaar tegenwicht te bieden. Per saldo is over het gehele jaar 2013 de werkgelegenheid in de Metalektro gedaald (zie Hoofdstuk 2).

\subsection{Ontwikkeling van werkgelegenheid in de Metalektro 1996-2012}

Uit cijfers van het CBS blijkt dat de werkgelegenheid in de Metalektro al jaren gestaag terugloopt, met een korte periode van stijging van 2006 tot 2008. Figuur 1.4 toont het indexcijfer voor de werkgelegenheid met als basisjaar 2001, welke op dit moment tot en met 2012 beschikbaar is. In 2011 en 2012 is de daling minder sterk dan in de directe voorgaande jaren. Op basis van Figuur 1.3 hierboven en de cijfers uit Hoofdstuk 2 verwachten wij dat de CBS cijfers ook voor 2013 een lichte daling in werkgelegenheid gaan laten zien. 
FIGUUR 1.4 Werkgelegenheid in de Metalektro, 1996-2012 (index met als basisjaar 2001)

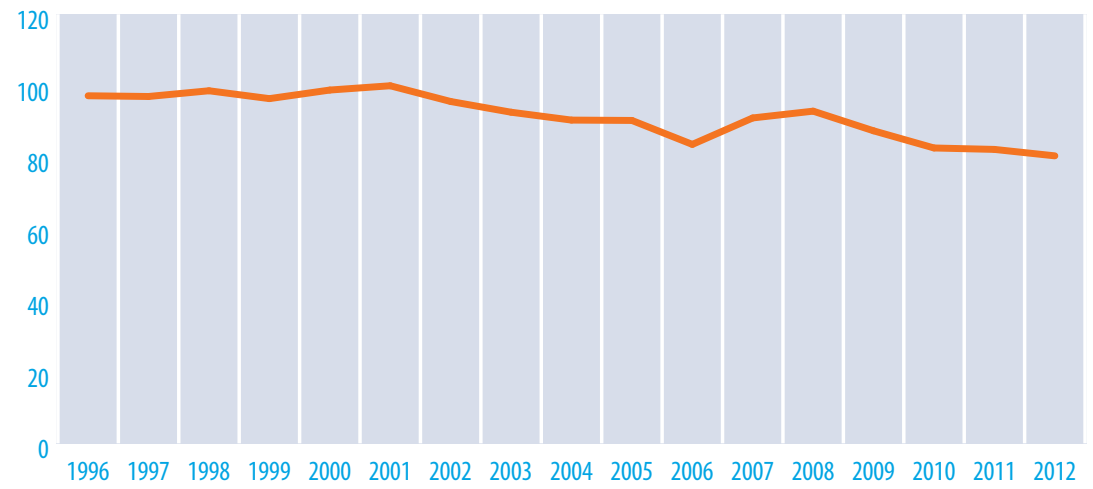

Bron: CBS, Enquête beroepsbevolking, 1996-2012

\subsection{Vergrijzing in de Metalektro}

Een blijvend aandachtspunt voor bedrijven in de Metalektro is de toenemende vergrijzing in de sector. Figuur 1.5 toont (gemeten op de rechter-as) dat de gemiddelde leeftijd in de sector al jaren gestaag toeneemt en ondertussen al de 42 gepasseerd is. Dit is het gevolg van het toenemend aandeel ouderen (50-64 jarigen), een dalend aandeel medewerkers van middelbare leeftijd (30-49) en een aandeel jongeren wat de laatste drie jaar stabiel is. Het aandeel ouderen in de sector is volgens de laatst beschikbare cijfers uit 2012 inmiddels 29\% en zal waarschijnlijk op dit moment al op 30-32 \% liggen.

FIGUUR 1.5 Leeftijdsverdeling in de Metalektro, 2006-2012

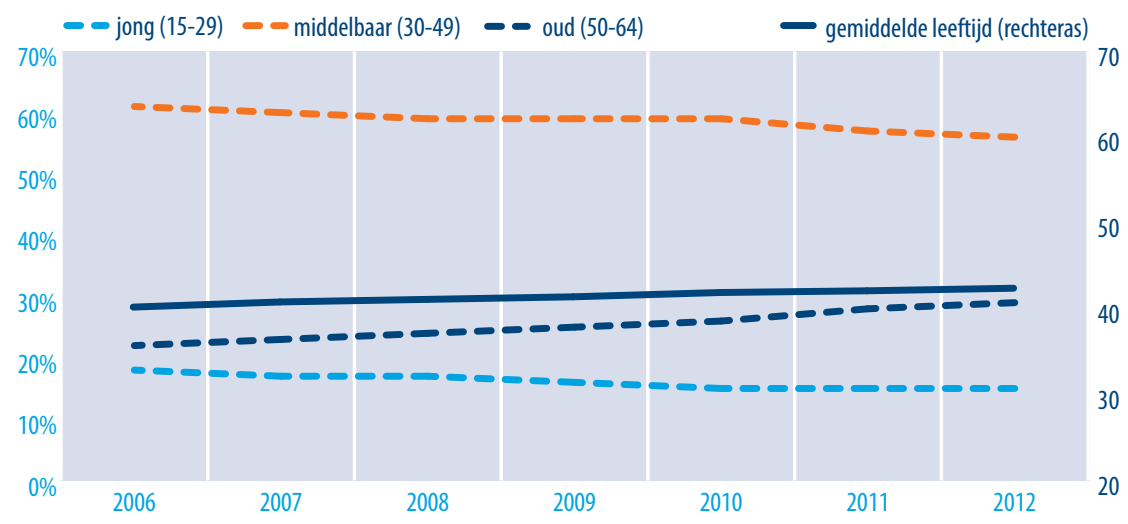

Bron: CBS, Enquête beroepsbevolking, 2006-2012 
TEKSTBOX 1.1 Hoe is de leeftijdsopbouw bij enkele individuele bedrijven in de sector?

De leeftijdsverdeling die voor de sector als geheel in Figuur 1.5 is weergegeven wordt bevestigd vanuit gesprekken met individuele bedrijven. Frans Kalkhoven, HR manager bij Toyota Material Handling geeft aan dat de gemiddelde leeftijd in hun bedrijf 48 jaar is. 0ok bij Royal Duyvis Wiener is behoorlijke vergrijzing aldus HR Manager Hilda Kluessien. $E r$ is in hun bedrijf echter ook een grote groep jongeren werkzaam maar er bestaat een soort 'gat' van medewerkers tussen de 35 en 45. Bij Mayfran International B.V. is de gemiddelde leeftijd, exclusief de flexibele schil, ongeveer 45 jaar, volgens Harrie van der Heijden, Manager Resources.

De nog altijd toenemende vergrijzing en de gevolgen die dit in de nabije toekomst kan hebben vormen al jaren een aandachtspunt voor de metalektrobedrijven. De vervanging van oudere medewerkers wordt misschien lichtjes uitgesteld vanwege een stijgende pensioenleeftijd, maar dit schuift het vraagstuk geen jaren vooruit. Uit Hoofdstuk 6 blijkt echter dat het percentage metalektrobedrijven dat problemen verwacht bij de vervanging van uittredende ouderen al jaren daalt. Het lijkt erop dat de metalektrobedrijven in toenemende mate met vertrouwen deze vervangingsuitdaging tegemoet zien. Welke strategieën de bedrijven daaromtrent nu reeds hanteren zal eveneens in Hoofdstuk 6 aan bod komen.

\subsection{Opleidingsniveau in de Metalektro}

Het gemiddelde opleidingsniveau in de Metalektro stijgt al jaren gestaag. Dit wordt vaak met de term 'upgrading' aangeduid. Figuur 1.6 toont hoe dit zich tussen 2002 en 2012 ontwikkeld heeft. In deze periode van 11 jaar is het aandeel hoger opgeleiden (HBO en WO) gegroeid van 18 tot $27 \%$. Tegelijkertijd is het aandeel lager opgeleiden (Basisonderwijs of VMBO) geleidelijk gedaald van bijna $35 \%$ tot $25 \%$. Het aandeel MBO opgeleiden leek tussen 2005 en 2011 gestaag te dalen maar is in 2012 toch weer $47 \% .^{2}$ Veruit de meeste dynamiek speelt zich dus af in een trendmatig dalend aandeel laag opgeleiden en een stijgend aandeel hoog opgeleiden. In 2011 leek deze trend nog even ten einde te zijn gekomen maar met de ontwikkelingen in 2012, waarin het aandeel hoger opgeleiden zelfs hoger dan ooit is geworden en het aandeel lager opgeleiden lager dan ooit, heeft de trend zich weer stevig doorgezet. Dit heeft in 2012 zelfs voor het eerst tot de situatie geleid waarin het aandeel hoog opgeleiden in de Metalektro groter is dan het aandeel laag opgeleiden ( 27 tegen 25 procent).

2 Op basis van de beschikbare cijfers is niet met zekerheid te concluderen of er binnen het aandeel MBO opgeleiden ook sprake is van upgrading, dat wil zeggen een stijgend aandeel MBO niveau 4 en een dalend aandeel $\mathrm{MBO}_{2} / 3$. De cijfers (niet getoond in een figuur) laten een stijging zien van het aandeel $\mathrm{MBO}_{4}$ opgeleiden tot en met 2010, maar een daling sindsdien. 
FIGUUR 1.6 Opleidingsniveau in de Metalektro 2006-2012

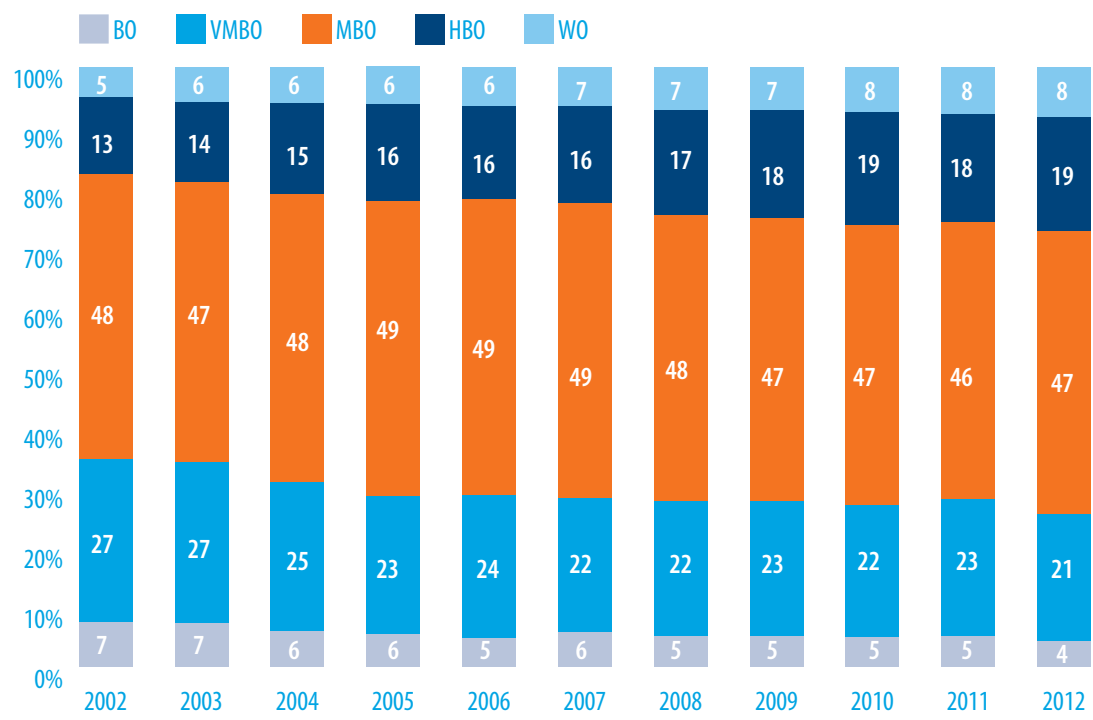

Bron: CBS, Enquête beroepsbevolking, 2006-2012

FIGUUR 1.7 Opleidingsniveau in Metalektro sectoren, 2012

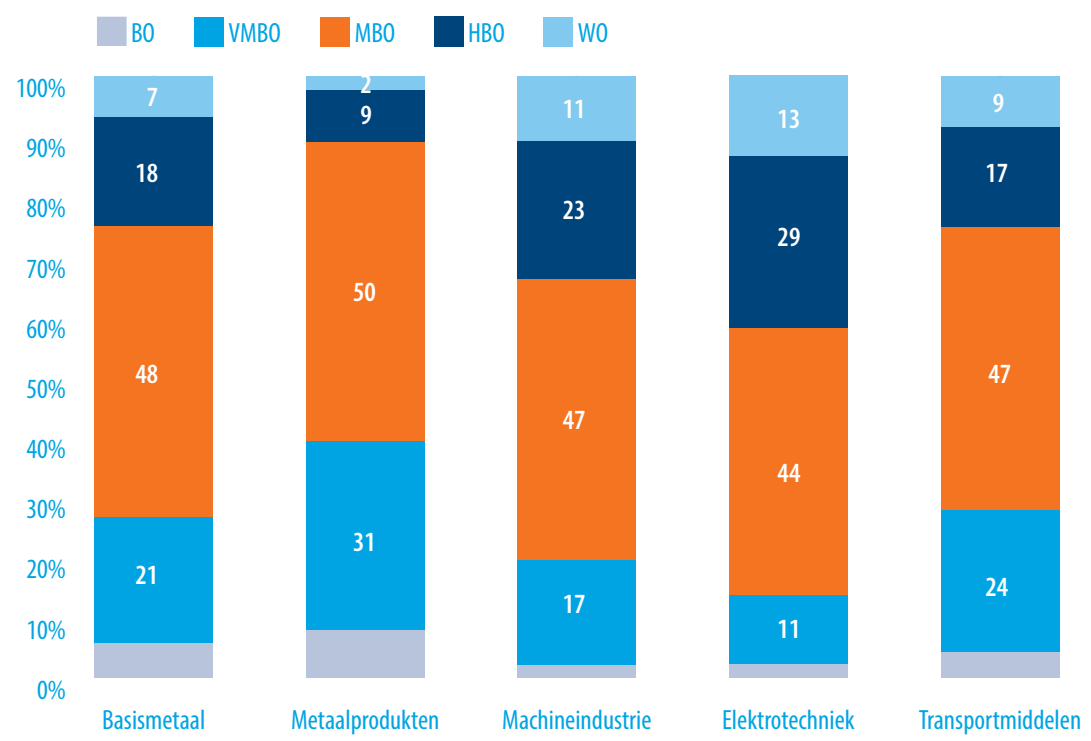

Bron: CBS, Enquête beroepsbevolking, 2012

Figuur 1.7 toont hoe het opleidingsniveau in 2012 verdeeld is binnen de verschillende sectoren in de Metalektro. Binnen de elektrotechniek vinden we, zoals ook in voorgaande jaren, veruit het hoogste percentage hoger opgeleiden en het laagste percentage lager 
opgeleiden. Het omgekeerde geldt voor de sector metaalproducten. In alle sectoren vormen de Mbo'ers de grootste groep, hoewel in de elektrotechniek het aandeel hoog opgeleiden al bijna net zo groot is als het aandeel Mbo'ers.

\subsection{Innovatie}

Figuur 1.8 toont over tijd wat de verwachtingen van de bedrijven zijn ten aanzien van hun toekomstige innovaties. Zo was het percentage bedrijven dat verwachtte productinnovaties te gaan ontwikkelen nog $72 \%$ in 2006 , om daarna gedurende de crisisjaren snel te dalen tot beneden de 50\%. In 2013 is dit percentage echter weer licht gestegen. Aangezien deze indicator voor productinnovaties sinds 2008 een grillig verloop van opeenvolgende stijgingen en dalingen kent, zouden we de lichte stijging in 2013 met scepsis kunnen beschouwen. Echter, eveneens gestegen in 2013 zijn het percentage bedrijven dat verwacht diensteninnovaties te ontwikkelen en het percentage bedrijven dat verwacht procesinnovaties te ontwikkelen. Daarmee zitten voor het eerst sinds 2008 de verwachtingen van de bedrijven voor alle typen innovatie weer in de lift. Voor de procesinnovaties is dit zelfs het tweede jaar op rij waarin de verwachtingen stijgen en deze stijging is sterker dan voor de andere typen innovaties.

FIGUUR 1.8 Verwachte innovaties (\% bedrijven voor de komende vijf jaar), 2006-2013

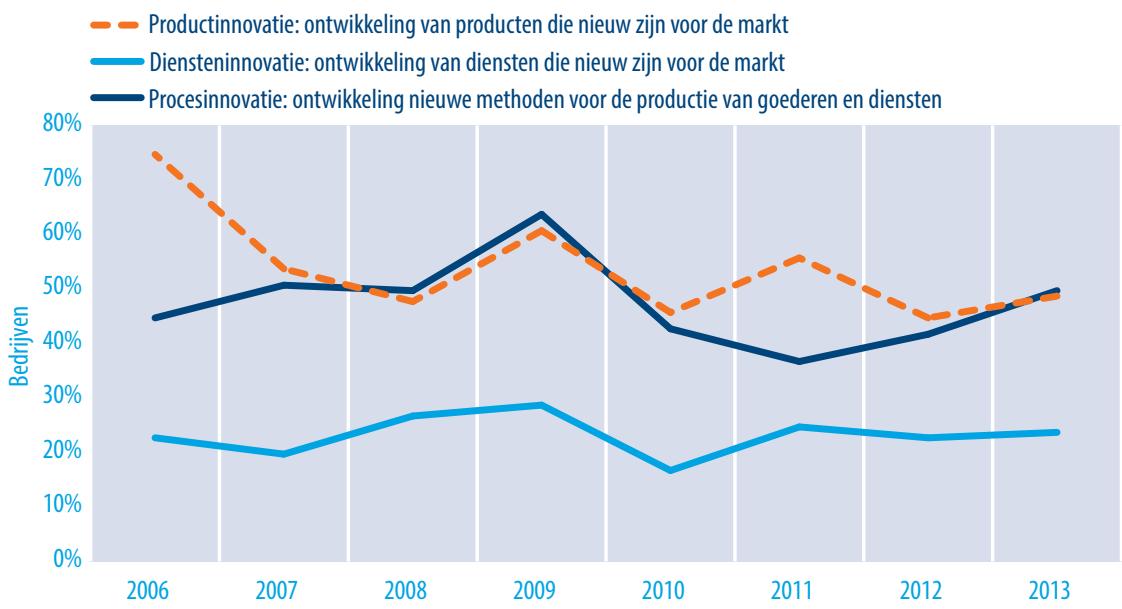

Bron: ROA, Arbeidsmarktmonitor Metalektro, 2006-2013 


\section{2 \\ ARBEIDSMARKTONTWIKKELINGEN METALEKTRO 2013}

Over de eerste helft van 2013 gold voor de sector als geheel een netto uitstroom van werknemers. Kijken we alleen naar uitvoerende technici, dan zien we echter in de eerste helft van 2013 dat er meer bedrijven met instroom waren dan bedrijven met uitstroom. In de tweede helft van het jaar is er nauwelijks meer sprake van netto uitstroom. Voor elke functiecategorie is het percentage met bedrijven dat aangeeft krimpende werkgelegenheid te hebben in de tweede helft van 2013 dan ook afgenomen. Verder blijkt dat de flexibele schil in de eerste helft van het jaar is gegroeid en een aanzienlijk groter deel van het totale personeelsbestand in de Metalektro is gaan vormen, waardoor bedrijven snel kunnen inspelen op schommelingen in de omzet. 
In de periode januari-juni 2013 was er bij 80\% van de bedrijven sprake van personeelsinstroom. ${ }^{3}$ Ook in de tweede helft van het jaar trok $77 \%$ van de bedrijven minimaal één nieuwe medewerker aan. Ten opzichte van 2012 is dit een positieve ontwikkeling. Toen namen iets minder bedrijven nieuw personeel aan, respectievelijk $74 \%$ van de bedrijven in de eerste helft en 66\% in de tweede helft van 2012.

Figuur 2.1 toont de percentages bedrijven met instroom in 2013 naar functiecategorie en jaarhelft. De meeste bedrijven trokken uitvoerende technici aan, wat ook traditioneel de grootste functiecategorie is. In de eerste helft van 2013 hebben zes op de tien metalektrobedrijven uitvoerend technisch personeel aangenomen. Dit liep in de tweede helft van het jaar terug, net als in 2012. In de meeste andere functiecategorieën is juist een tegenovergestelde ontwikkeling te zien. Voor deze functies nam het percentage bedrijven met personeelsinstroom in de loop van het jaar juist toe. Dit is het geval voor zowel de ondersteunende technische als niet-technische functies, leidinggevende technische functies en voor engineering en R\&D-functies. In zowel de eerste als de tweede helft van het jaar hebben bedrijven die behoren tot het MKB, ten opzichte van grote bedrijven, significant minder vaak nieuw personeel aangetrokken voor de meeste functiecategorieën.

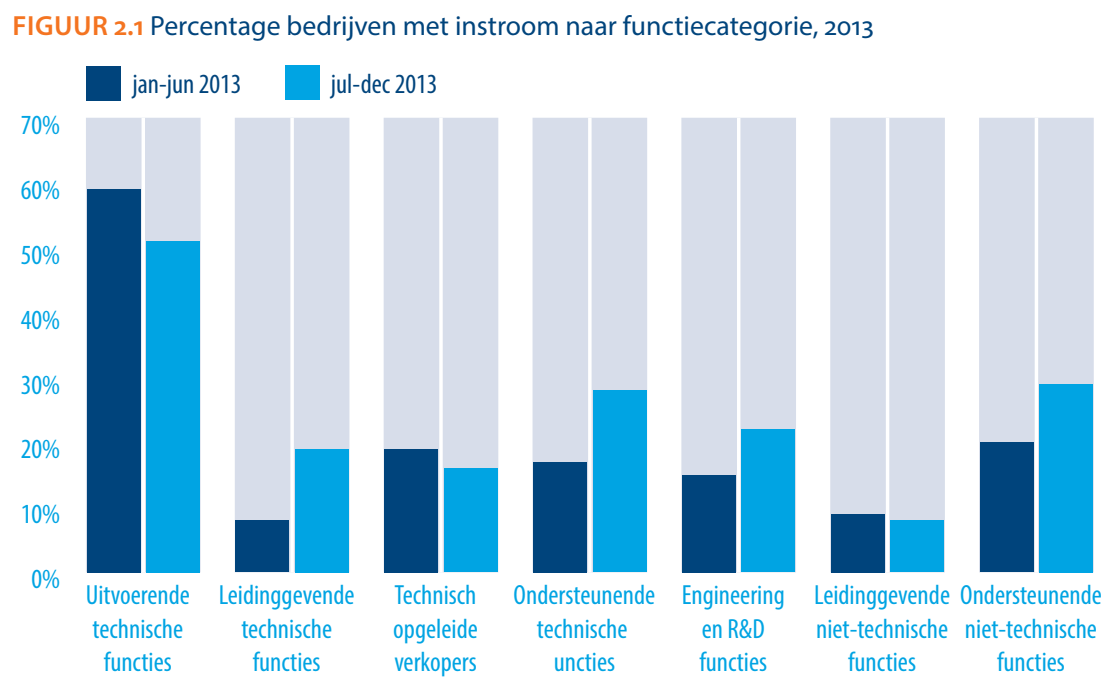

Bron: ROA, Arbeidsmarktmonitor Metalektro, 2013

3 De personeelsinstroom heeft betrekking op nieuwe medewerkers die bij metalektrobedrijven in loondienst komen. Medewerkers die door bedrijven worden ingeleend, maar die niet bij hen in dienst zijn, komen verderop in dit hoofdstuk aan bod in paragraaf 2.4 . 
In 2013 had 65\% van de metalektrobedrijven in de eerste helft van het jaar te kampen met personeelsuitstroom en in de tweede helft was dit vrijwel onveranderd (66\%). Dit is lager dan in 2012 toen gemiddeld $72 \%$ van de bedrijven te maken had met uitstroom.

Figuur 2.2 toont het percentage bedrijven met personeelsuitstroom in de eerste en tweede helft van 2013 voor de verschillende functiecategorieën. Bij de beide leidinggevende functiecategorieën en de ondersteunende niet-technische functies waren er in de tweede helft van 2013 iets meer bedrijven met uitstroom. Voor de technisch opgeleide verkopers, ondersteunende technici en engineering en R\&D-personeel nam het percentage bedrijven met uitstroom in de tweede helft van het jaar iets af. Zeker in de tweede helft van 2013 was de personeelsuitstroom van grote bedrijven in vrijwel alle functiecategorieën significant hoger dan bij het MKB.

FIGUUR 2.2 Percentage bedrijven met uitstroom naar functiecategorie, 2013

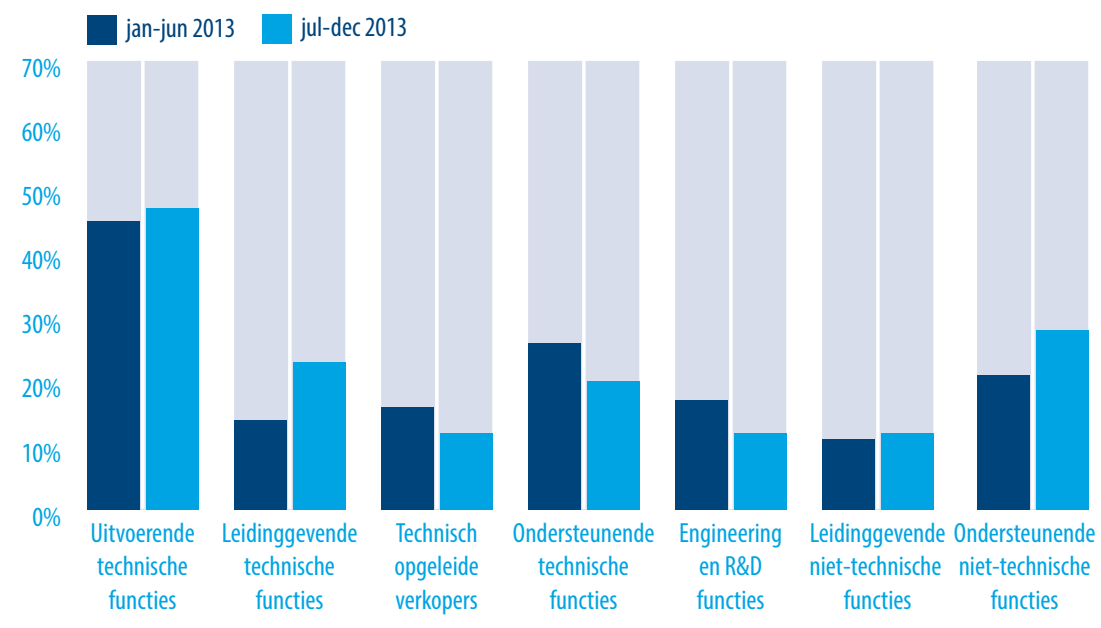

Bron: ROA, Arbeidsmarktmonitor Metalektro, 2013

Een vergelijking van de bedrijven met instroom per functiecategorie (Figuur 2.1) en de bedrijven met uitstroom per functiecategorie (Figuur 2.2) leert dat er in 2013 per saldo meer bedrijven zijn met personeelsinstroom binnen de uitvoerende technische functies, de technisch opgeleide verkopers en de engineering en R\&D-functies. Dit is in tegenstelling tot de beide leidinggevende functiecategorieën waarvoor geldt dat er per saldo meer bedrijven waren die personeel uit de betreffende functies zagen vertrekken. Voor de ondersteunende functies (zowel technisch als niet-technisch) geldt dat er in de eerste helft van 2013 sprake was van een surplus aan bedrijven met uitstroom uit deze functies, maar dat dit beeld in de tweede helft van het jaar kantelde waardoor bedrijven met personeelsinstroom in deze functiecategorieën de overhand kregen. 
Uitvoerende technische functies nader bekeken: de dynamiek in de grootste functiecategorie

Aan de hand van Figuur 2.3 wordt nader ingegaan op de arbeidsmarktdynamiek van de grootste functiecategorie, het uitvoerend technisch personeel. De figuur toont het percentage bedrijven met in- c.q. uitstroom voor de periode 2005-2013. Met de intrede van de economische crisis nam het aantal bedrijven dat nieuwe medewerkers voor deze functiecategorie aantrok fors af. Vervolgens krabbelde tussen 2009 en 2011 het percentage bedrijven met instroom langzaam maar zeker weer op en in de eerste helft van 2011 trokken bijna twee op de drie metalektrobedrijven uitvoerende technici aan. Sindsdien is er sprake van een fluctuerend verloop met een dalende trend. Daarbij valt op dat in de afgelopen drie jaar minder bedrijven in de tweede jaarhelft uitvoerend technisch personeel aantrokken dan in de eerste jaarhelft. Het percentage bedrijven dat met uitstroom van uitvoerende technici te maken had is tussen 2008 en 2013 met niet minder dan 30\%-punt afgenomen. Verder kan uit Figuur 2.3 worden afgeleid dat vanaf 2011 bedrijven met instroom van personeel de overhand hebben. Door fluctuaties in de instroom is dit surplus in genoemde periode overigens vooral terug te zien in de eerste helft van de betreffende jaren. Terwijl het percentage bedrijven met instroom van uitvoerend technisch personeel in de eerste helft van 2013 bijvoorbeeld 15\%-punt hoger was dan het percentage bedrijven met uitstroom, bedraagt dit verschil in de tweede helft van het jaar nog 4\%-punt.

FIGUUR 2.3 Percentage met in- c.q. uitstroom van uitvoerend technisch personeel, 2005-2013

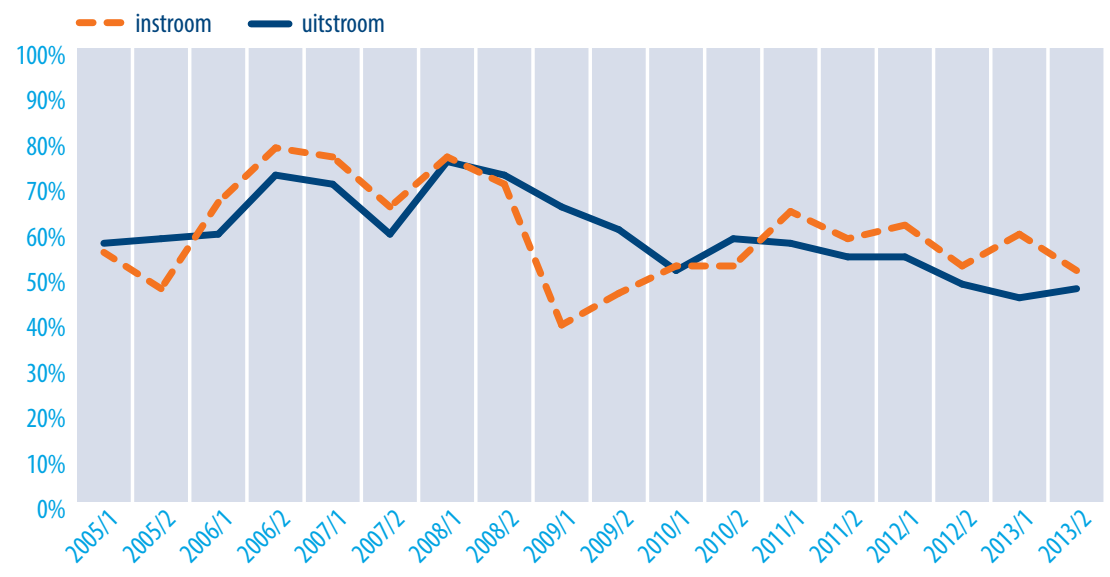

Bron: ROA, Arbeidsmarktmonitor Metalektro, 2005-2013 


\subsection{Werkgelegenheidsontwikkeling verschilt sterk per functie}

In tegenstelling tot paragrafen 2.1 en 2.2 waar het ging om de vraag of bedrijven nieuwe medewerkers hebben aangetrokken of afscheid hebben genomen van medewerkers, staat in paragraaf 2.3 de vraag centraal in welke mate dit in 2013 het geval was. Het instroompercentage en het uitstroompercentage zijn berekend door per functiecategorie het aantal nieuwe, respectievelijk vertrokken, medewerkers te delen door het totaal aantal werknemers in loondienst. Figuur 2.4 toont deze werkgelegenheidsontwikkelingen en maakt onderscheid tussen de eerste en de tweede helft van 2013. In de eerste helft van 2013 overtrof het uitstroompercentage $(4,5 \%)$ het instroompercentage $(3,8 \%)$. Dit betekent dat er bij metalektrobedrijven tussen januari en juni per saldo meer personen vertrokken dan aangenomen zijn. Deze werkgelegenheidsafname in de eerste helft van het jaar is bovendien in vrijwel elke functiecategorie terug te zien. Enige uitzondering hierop vormt de functiecategorie engineering en R\&D-functies. In deze functiecategorie was sprake van een lichte werkgelegenheidstoename. Het uitstroomoverschot in de eerste helft van 2013 was het grootst voor ondersteunende technische functies en leidinggevende niet-technische functies.

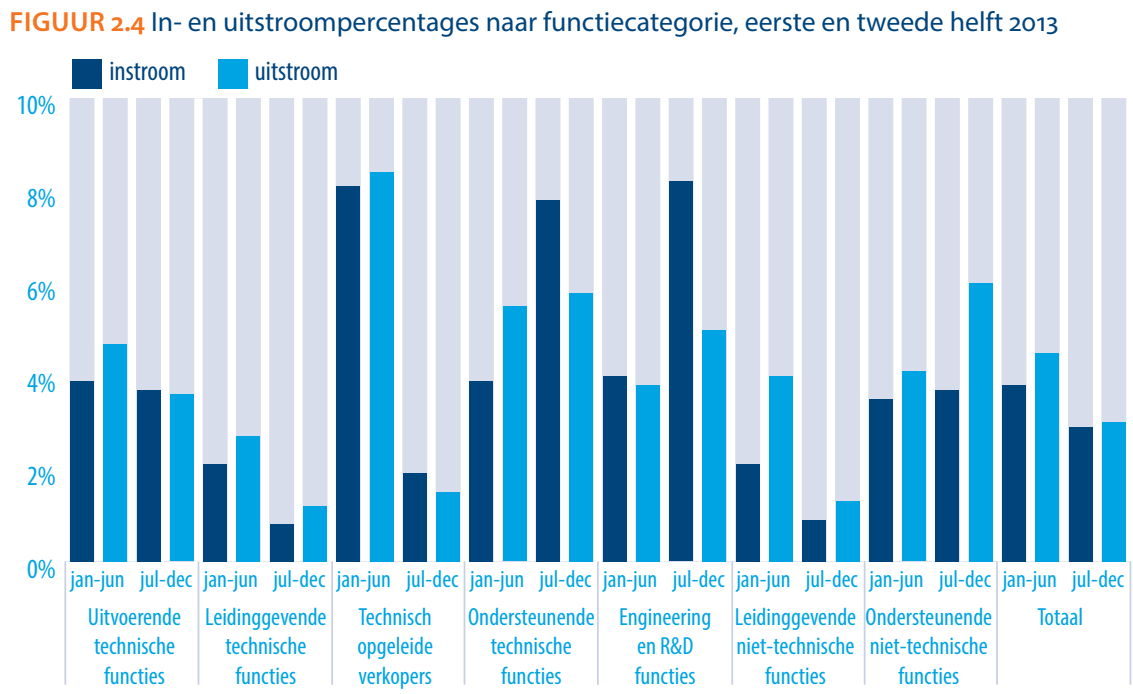

Bron: ROA, Arbeidsmarktmonitor Metalektro, 2013

In de tweede helft van 2013 waren de totale instroom en uitstroom nagenoeg in balans. Echter, uit de figuur blijkt dat er grote verschillen in werkgelegenheidsontwikkeling bestaan tussen de functiecategorieën. ${ }^{4}$ Voor ondersteunend technisch personeel en engineering en $R \& D$ personeel nam de werkgelegenheid in de tweede helft van 2013

$4 \quad$ In deze figuur zijn ingeleende medewerkers niet inbegrepen. Het gaat dan ook uitsluitend om medewerkers die bij het werkgeverspanel in loondienst waren. Op de groep ingeleende personen wordt nader ingegaan in paragraaf 2.4. 
duidelijk toe. De instroom overtrof hier duidelijk de uitstroom. Ook de functiecategorie technisch opgeleide verkopers kende een lichte netto instroom. Opvallend is verder dat er per saldo meer uitstroom was voor met name de ondersteunende niet-technische functies en in mindere mate de leidinggevende technisch en niet-technische functies. Het instroompercentage voor uitvoerende technische functies $(3,7 \%)$ wijkt nauwelijks af van het uitstroompercentage voor deze functiecategorie $(3,6 \%)$. In totaal overtrof de uitstroom in 2013 de instroom en daalde de werkgelegenheid licht.

\section{Minder bedrijven met krimpende werkgelegenheid in 2e helft van het jaar}

Figuur 2.5 laat per functiecategorie zien hoeveel procent van de bedrijven in de eerste helft en de tweede helft van 2013 te kampen had met krimpende werkgelegenheid. Afgaande op de figuur was er binnen 2013 sprake van een positieve ontwikkeling. Immers, het percentage bedrijven dat te kampen had met afnemende werkgelegenheid nam in de tweede helft van het jaar in elke functiecategorie af. Zo moest in de tweede helft van 2013 18\% van de bedrijven snijden in de omvang van het uitvoerend technisch personeel, terwijl dit in de eerste helft van het jaar nog één op de drie bedrijven was. Ook binnen de ondersteunende niet-technische functies en de engineering en R\&D-functies nam het percentage bedrijven dat te kampen had met krimpende werkgelegenheid in de tweede helft van het jaar sterk af (-11\%-punt). Daarnaast nam in de loop van het jaar ook het percentage bedrijven met afnemende werkgelegenheid af wat betreft twee andere technische functiecategorieën: de leidinggevende technische functies en de ondersteunende technische functies.

FIGUUR 2.5 Percentage bedrijven met krimpende werkgelegenheid naar functiecategorie, 2013

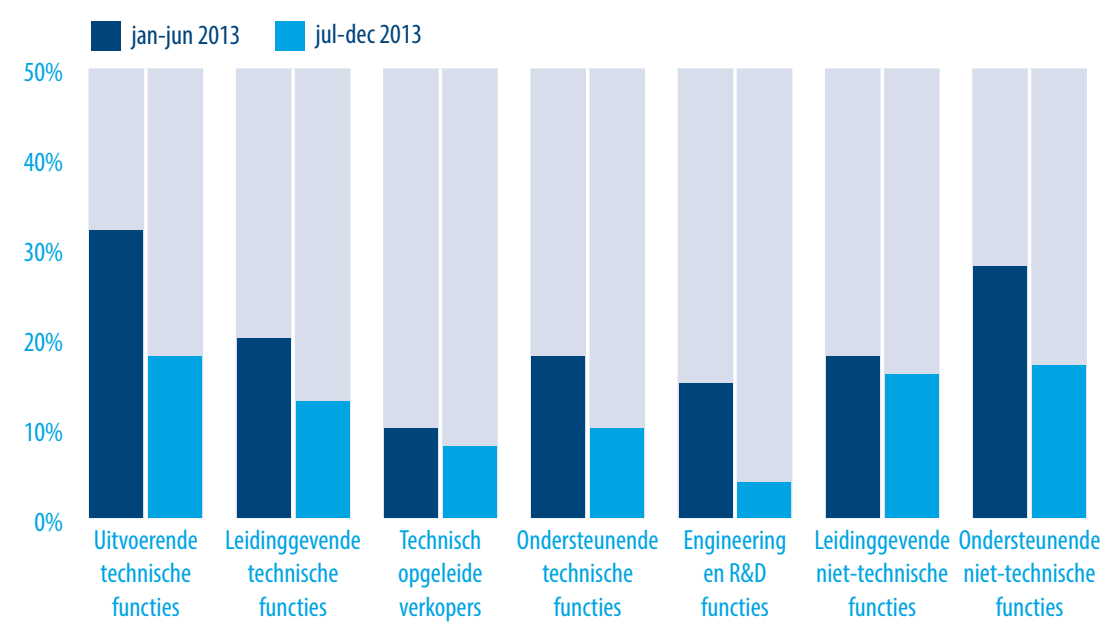

Bron: ROA, Arbeidsmarktmonitor Metalektro, 2013 
Hoe gaven de bedrijven, die daarmee te maken hebben gehad, vorm aan de krimpende werkgelegenheid? Figuur 2.6 toont dat bedrijven hier in 2013 deels anders mee om zijn gegaan dan in 2012. In 2012 resulteerde de krimpende werkgelegenheid nog het vaakst in een vacaturestop, maar in 2013 is dit percentage gehalveerd. De twee vaakst genoemde gevolgen van de krimpende werkgelegenheid in 2013 zijn dat tijdelijke contracten niet langer worden verlengd en dat medewerkers die met pensioen gaan niet worden vervangen. Beide maatregelen werden in 2013 genomen bij ruim vier op de tien bedrijven die te kampen hadden met teruglopende werkgelegenheid. Twee andere gevolgen van de krimpende werkgelegenheid werden in 2013 duidelijk vaker genoemd dan in 2012. In 2013 verlieten medewerkers vaker het bedrijf op eigen initiatief en werden werknemers vaker overgeplaatst naar andere functies binnen het bedrijf om krimpende werkgelegenheid. Beide kwamen bij meer dan twee keer zoveel bedrijven met krimp voor dan in 2012. Tot slot waren er in 2013 iets meer bedrijven die zich genoodzaakt zagen tot gedwongen ontslagen. Dit was in 2013 het geval bij ruim een kwart van de bedrijven met personeelskrimp.

FIGUUR 2.6 Gevolgen krimpende werkgelegenheid van technisch personeel, 2012-2013

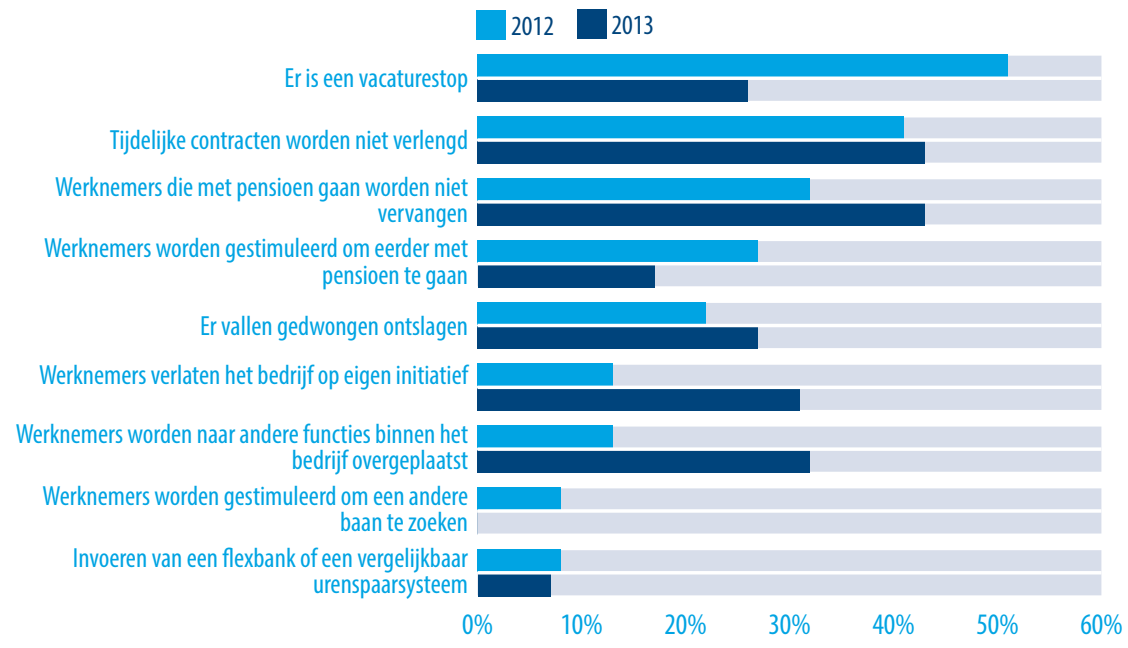

Bron: ROA, Arbeidsmarktmonitor Metalektro, 2012-2013

\subsection{Forse toename flexibele schil in eerste helft 2013}

Als gevolg van de economische crisis werd de afgelopen jaren flink gesneden in de omvang van de flexibele schil in de Metalektro (zie Figuur 2.7). Deze dalende tendens ging door tot en met januari 2013. Vanaf januari 2013 vond er een kentering plaats en groeide de flexibele schil voor het eerst weer, kort daarvoor ingeleid door het opkrabbelen van de omzetgroei. Deze begon in oktober 2012, hoewel nog altijd negatief, weer te toe te nemen. Zowel de omzetgroei als de groei in de flexibele schil zetten door gedu- 
rende 2013. De omzetgroei bereikte zelfs weer positieve waarden vanaf najaar 2013. De grootste groei van de flexibele schil vond plaats in de eerste helft van het jaar. Tussen januari en juli groeide de flexibele schil met maar liefst 21\%-punt, van 11\% naar 32\%. In januari 2014 bleek dit percentage nog iets te zijn gestegen en had 35\% van de werknemers in de Metalektro een flexibel contract. Een nadere blik op de flexibele schil leert dat deze in juli grotendeels bestond uit werknemers met een tijdelijk contract. Er waren toen ruim tweemaal zoveel personen met een tijdelijk contract dan dat er personen ingeleend werden. Tussen juli 2013 en januari 2014 is het aandeel ingeleende personen ook aanzienlijk toegenomen en bijna net zo groot als het aandeel personen met een tijdelijk contract.

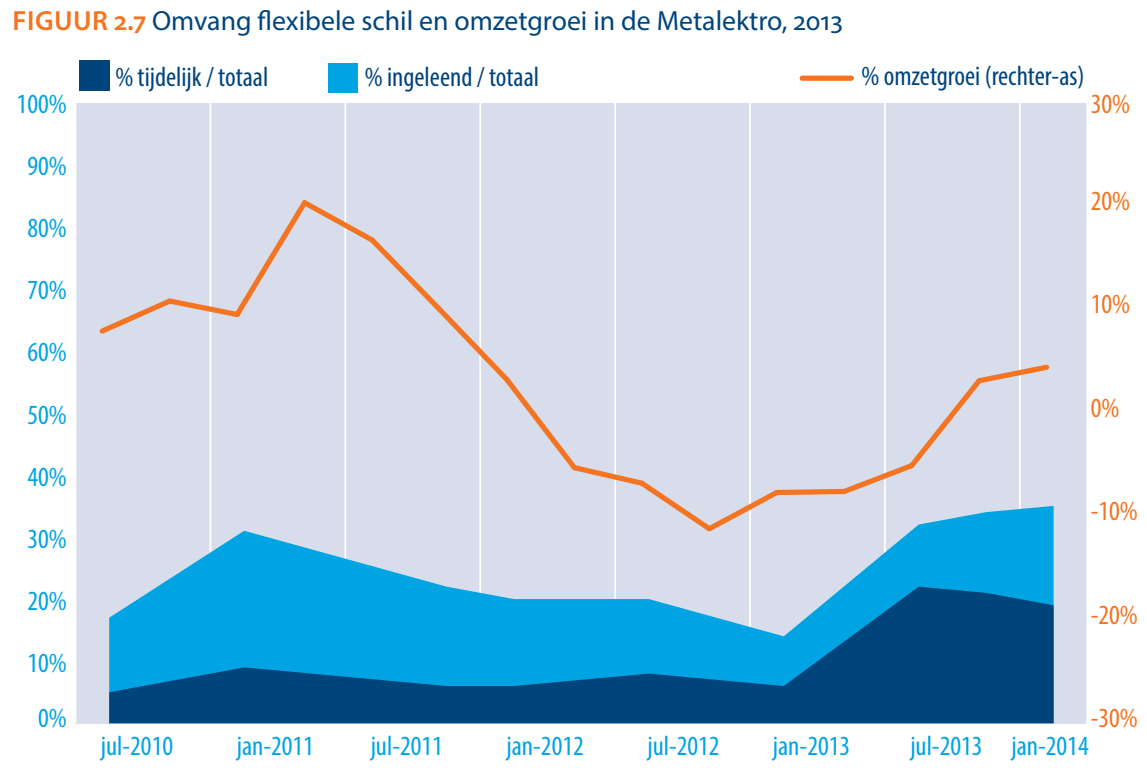

Bron: ROA, Arbeidsmarktmonitor Metalektro, 2012-2013/ Figuur overgenomen uit: Gerards, R. (2014), Tijdelijke contracten mogelijk voorbode langer herstel. Economisch Statistische Berichten. 99 (4681), 177.

\subsection{Ontwikkeling van de flexibele schil naar functiecategorie}

De uitbreiding van de flexibele schil op meetmoment juli 2013 is niet toe te schrijven aan één specifieke of enkele functiecategorie(ën) maar is terug te zien in elke functiecategorie (zie Figuur 2.8). Tussen januari en juli 2013 steeg de flexibele schil het sterkst binnen de uitvoerende technische functies, de ondersteunende technische en niettechnische functies alsook de engineering en R\&D-functies. Van het uitvoerend technisch personeel had in juli 2013 zelfs iets meer dan de helft een flexibel contract. De flexibele schil in genoemde functiecategorieën is vooral groot doordat een groot deel van de werkenden een tijdelijk contract heeft. Binnen de uitvoerende technische functies 
had in juli 35\% een tijdelijk contract en in de ondersteunende functies en de engineering en R\&D-functies was dit (ruim) een kwart van de werkenden. Binnen de beide leidinggevende functiecategorieën steeg het aandeel flexibele contracten veel minder en bleef een vast contract de standaard.

De sterke toename van de flexibele schil in de verschillende functiecategorieën stabiliseerde in de tweede helft van het jaar. Tussen juli 2013 en januari 2014 nam het percentage flexibele arbeidskrachten nog licht toe onder uitvoerende en leidinggevende technici, leidinggevende niet-technische functies en engineering en R\&D-functies. Het percentage flexibele contracten voor technisch opgeleide verkopers en ondersteunende functies nam daarentegen af in de tweede helft van het jaar. Voor ondersteunende functies is deze afname het sterkst, maar had op meetmoment januari 2014 nog altijd $20 \%$ van de medewerkers een flexibel contract, wat meer is dan in januari 2013.

\section{FIGUUR 2.8 Ontwikkeling flexibele schil (\% medewerkers) naar functiecategorie}

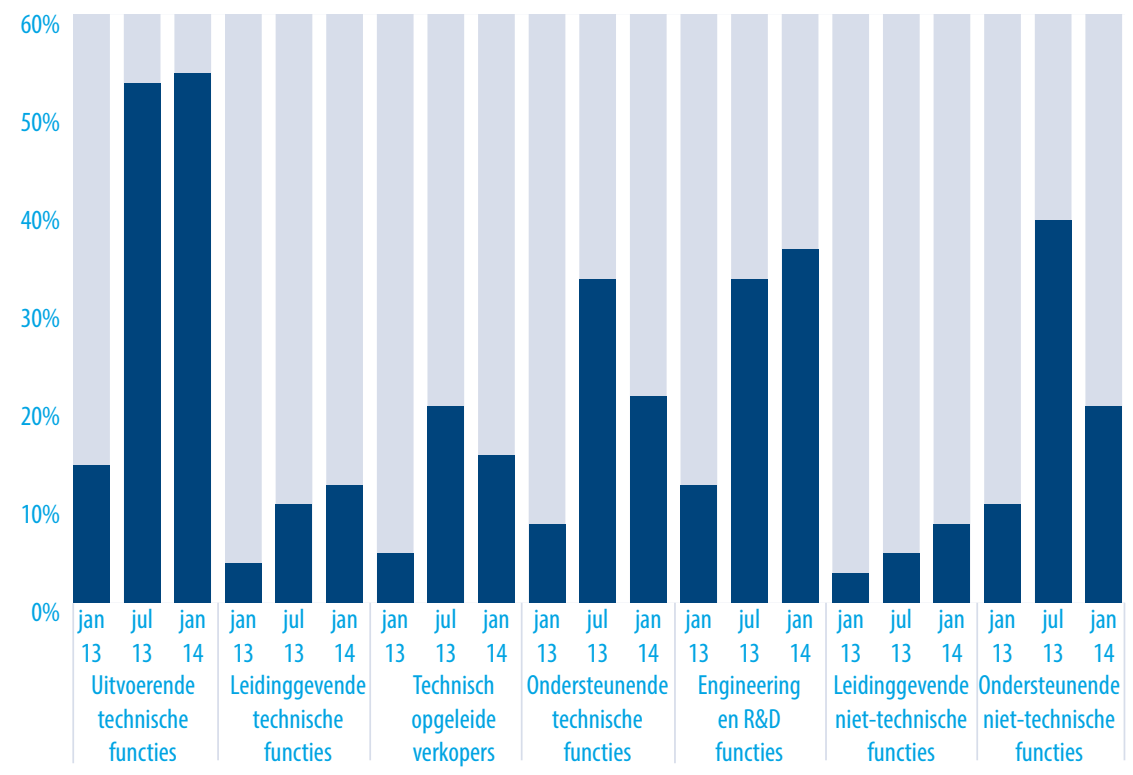

Bron: ROA, Arbeidsmarktmonitor Metalektro, 2013

Noot: Het overige, niet in de figuur weergegeven, deel van de dienstverbanden in elke functiecategorie bestaat uit medewerkers in vaste loondienst. Het percentage medewerkers met een vast contract plus het percentage met een flexibel contract tellen samen op tot $100 \%$. 



\section{3 \\ VACATURES EN WERVING}

In 2013 waren er in de Metalektro voor de meeste functiecategorieën meer bedrijven met vacatures. De meeste van deze vacatures zijn ontstaan door een toename van de hoeveelheid werk. Ondanks de toename van het aantal vacatures hadden bedrijven minder langdurig openstaande vacatures of wervingsproblemen. Als dat al het geval was dan kwam het vooral doordat sollicitanten niet de juiste competenties hadden of onvoldoende werkervaring, al waren er ook bedrijven die aangaven dat er voor bepaalde vacatures te weinig sollicitanten waren. Wervingsproblemen werden te lijf gegaan met een keuze uit beproefde strategieën, zoals het bieden van goede loopbaanperspectieven, het inschakelen van externe bureaus, het aantrekken van mensen met minder ervaring, flexibele inzet van huidige medewerkers, overwerk, om/bijscholing en een andere organisatie van het werk. Over het algemeen werden de traditioneel populaire en effectieve wervingskanalen (uitzendbureaus, werving-en selectiebureaus) ook in 2013 weer het best beoordeeld. Daarnaast beleefde de effectiviteit van het internet als wervingskanaal een bescheiden opleving. 


\subsection{Meer bedrijven met vacatures en vacatures sneller ingevuld}

De arbeidsmarkt in de Metalektro ontwikkelde zich in 2013 weer in opwaartse richting. Ten opzichte van de tweede helft van 2012 (gemeten in januari 2013) waren er voor de meeste functiecategorieën in 2013 meer bedrijven met vacatures. Dit toont Figuur 3.1, waarin het percentage bedrijven met vacatures wordt getoond naar functiecategorie. Voor de meeste functiecategorieën vormde de tweede helft van 2012 een dieptepunt in percentage bedrijven met vacatures. De functiecategorieën uitvoerende, leidinggevende en ondersteunende technici, ondersteunende niet-technici en engineering en $R \& D$, klommen in 2013 allen uit het dal en eindigden het jaar met een hoger percentage bedrijven met vacatures dan in januari 2013. Voor technisch opgeleide verkopers geldt dat er in de eerste helft van 2013 iets meer bedrijven met vacatures waren maar dat dit in de tweede helft van 2013 weer terugliep. Voor leidinggevende niet-technische functies loopt het percentage bedrijven met vacatures al sinds 2011 terug. Ondanks deze voorzichtige stijging in het percentage bedrijven dat vacatures heeft voor de meerderheid van functiecategorieën, blijven de percentages nog ver achter bij die van 2010 en 2011.

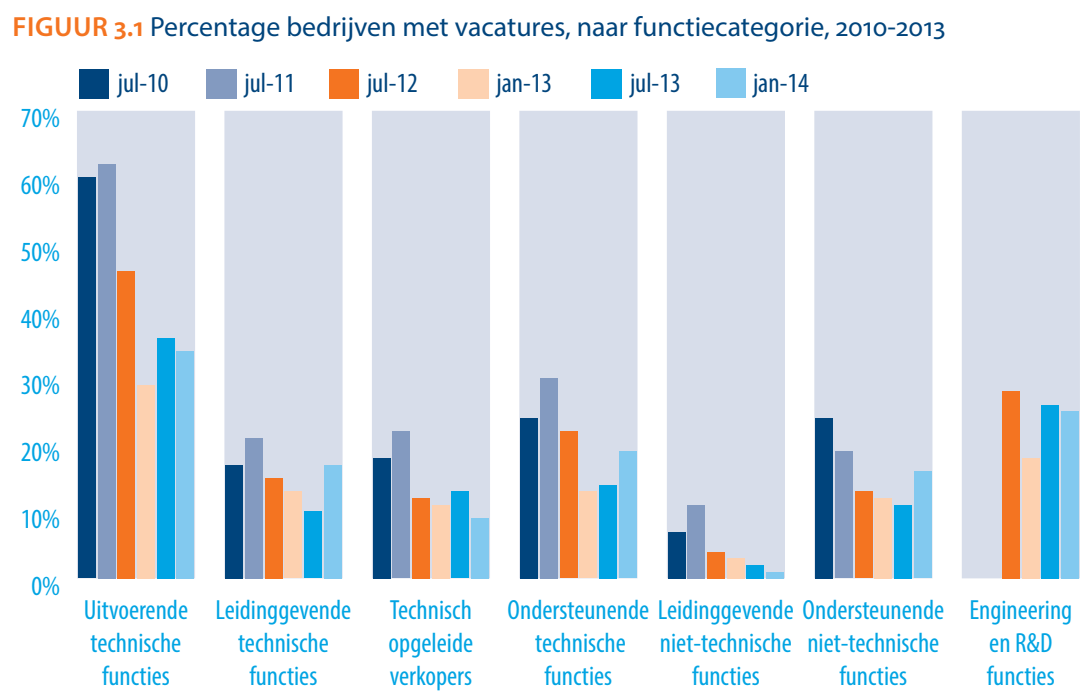

Bron: ROA, Arbeidsmarktmonitor Metalektro, 2013

Ondanks dat er in 2013 voor de meeste functiecategorieën meer bedrijven waren met vacatures is de duur van vacatures voordat deze vervuld werden in 2013 niet gestegen. In tegendeel, zowel het aandeel vacatures dat langer dan een jaar open stond en het aandeel vacatures dat 6 tot 12 maanden open stond is in 2013 gedaald. Dit is te zien in Figuur 3.2, waarin de twee meest lichtblauwe curves tussen januari 2013 en oktober 2013 steeds dunner werden. In het laatste kwartaal van 2013 is wel nog een kleine toename te zien in langdurig openstaande vacatures ( > 1 jaar) maar 2013 is desalniettemin geëindigd met minder langdurig openstaande vacatures dan toen het jaar begon. De arbeids- 
markt in 2013 was in de Metalektro dus ruimer dan in 2012. Dit is niet onlogisch gezien de fors opgelopen werkloosheid op macroniveau, die al lang niet meer uit enkel een granieten laag bestaat maar nu in toegenomen mate uit mensen met recente en actuele werkervaring, die op korte termijn te werven en in te zetten zijn.

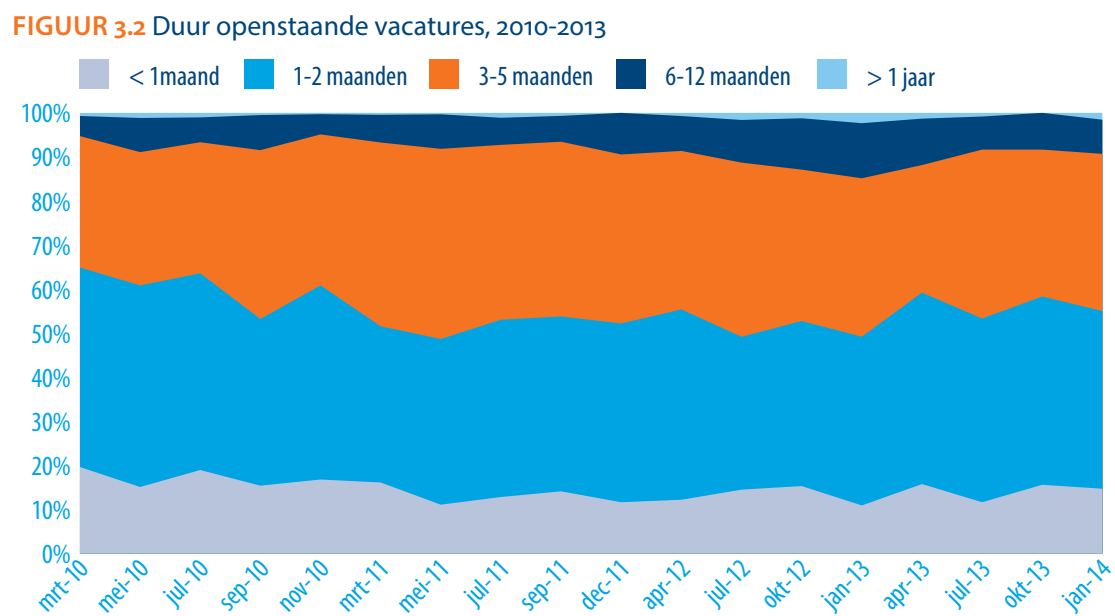

Bron: ROA, Arbeidsmarktmonitor Metalektro, 2010-2013

\subsection{Vacatures voornamelijk gevolg van toename in hoeveelheid werk}

Om te kunnen bepalen wat de toegenomen hoeveelheid bedrijven met vacatures in 2013 betekent in termen van economisch herstel in de sector, is het van belang om te kijken naar de ontstaansreden van de vacatures. Als vacatures bijvoorbeeld voornamelijk het gevolg zijn van pensioneringen dan dienen ze (slechts) ter vervanging van vertrekkend personeel. Zijn vacatures echter veroorzaakt door een toename in hoeveelheid werk dan is dit een sterker signaal dat de toename in vacatures ook een onderliggende verbetering in (bedrijfs)economische situatie weerspiegelt. In Figuur 3.3 tonen we daartoe de ontstaansredenen van vacatures voor technici voor de laatste vijf halve jaren.

Een toename in de hoeveelheid werk is de afgelopen jaren altijd de meest voorkomende reden geweest voor vacatures. Aan deze toppositie heeft de crisis in die zin niks veranderd. Echter, aan het begin van 2013, in januari, waren de percentages van vacatures die ontstaan waren als gevolg van personeel dat vrijwillig vertrekt (41\%) en personeel dat met (pre)pensioen ging (35\%), dicht genaderd tot het percentage vacatures dat door een toename in werk was ontstaan (46\%). In de loop van 2013 is echter de toename van hoeveelheid werk weer belangrijker geworden als ontstaansreden voor vacatures en zijn bijna alle andere redenen minder prominent geworden. Ten opzichte van januari 2013 zijn er minder vacatures als gevolg van vrijwillig vertrek, pensionering, interne mobiliteit en gedwongen vertrek, hoewel bij gedwongen vertrek in de tweede helft van 
2013 toch nog een stijging plaats vond ten opzicht van de eerste helft van 2013. Vacatures als gevolg van (langdurige) ziekte spelen al twee jaar een bijrol in deze figuur.

Per saldo zat het aandeel vacatures dat is ontstaan vanuit het uitbreidingsmotief (toename hoeveelheid werk) dus duidelijk in de lift in 2013 en daalde het aandeel vacatures dat vanuit een vervangingsmotief is ontstaan (vrijwillig of gedwongen vertrek, pensioen, interne mobiliteit, ziekte). Dit wijst op een onderliggende positieve (bedrijfs) economische ontwikkeling.

FIGUUR 3.3 Ontstaansreden van vacatures voor technici, 2012-2013

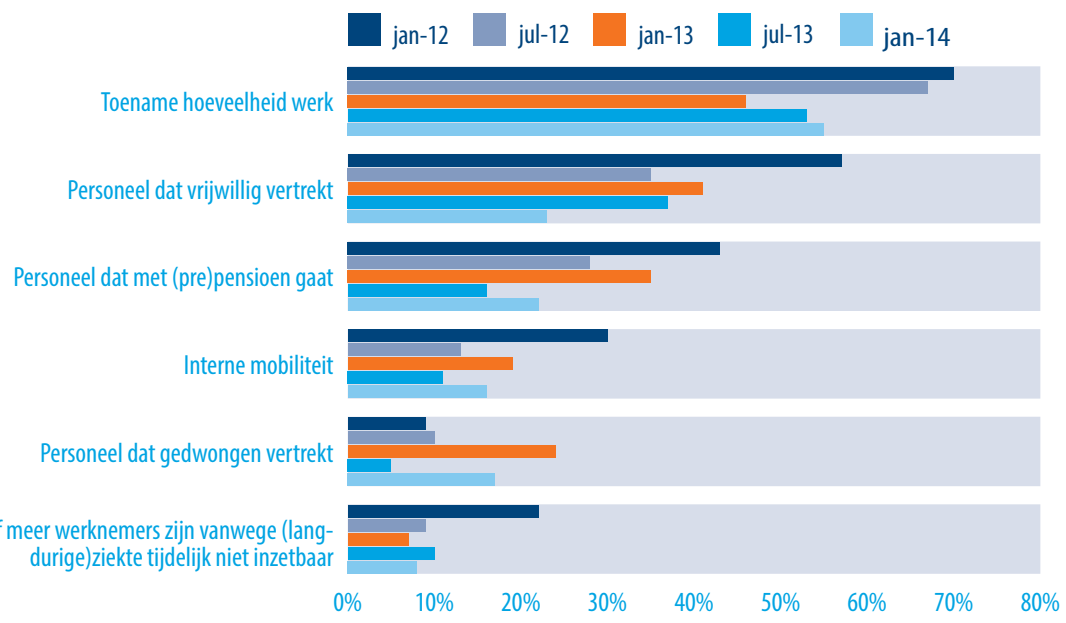

Bron: ROA, Arbeidsmarktmonitor Metalektro, 2013

De ontstaansredenen voor vacatures kunnen verder onderzocht worden door te kijken of vacatures hoofdzakelijk ontstaan als gevolg van een reeds bestaande situatie (waardoor het bedrijf gedwongen wordt om een vacature te plaatsen) of dat de vacatures ontstaan doordat er door het bedrijf proactief ingespeeld wordt op een verwachte toekomstige ontwikkeling (zie Figuur 3.4). Zo werden vacatures voor technisch personeel die ontstaan zijn door een toename van de hoeveelheid werk in 2013 in sterk toenemende mate op pro-actieve wijze ingevuld. Begin 2013 werd amper een kwart van deze vacatures (als gevolg van meer werk) op pro-actieve wijze ingevuld terwijl dit in januari 2014 al voor de helft van deze vacatures gold. Bedrijven wisten dus steeds vaker dat de toename in hoeveelheid werk eraan zat te komen en konden daarop alvast vacatures openen.

Een toename in proactieve geopende vacatures zagen we in 2013 ook voor de ontstaansredenen dat personeel met (pre)pensioen gaat en interne mobiliteit. Van alle bedrijven die vacatures hebben omdat personeel met (pre)pensioen gaat, gaf eind 2013 56\% aan nu al een vacature geplaatst te hebben om tijdig in te kunnen spelen op de positie die later vrij zal komen. Ook vacatures als gevolg van interne mobiliteit ontstonden eind 2013 
iets vaker uit proactief handelen dan begin 2013. Eind 2013 ontstond $20 \%$ van deze vacatures proactief terwijl dit begin 2013 11\% was. Dit percentage schommelt sterk zonder duidelijk patroon, want iets verder terug in de tijd, gemeten in juli 2012, werd proactief ingespeeld op maar liefst $43 \%$ van de vacatures door interne mobiliteit. Traditioneel gezien is het lastiger voor bedrijven om proactief beleid te voeren op de andere vaak genoemde reden voor vacatures, i.e. personeel dat vrijwillig vertrekt. Voor deze reden geven maar weinig bedrijven aan dat ze hierop proactief kunnen inspelen (11\%). Dit is natuurlijk ook moeilijk om aan te zien komen waardoor de overgrote meerderheid (89\%) aangeeft dat zij de vacature pas geplaatst hebben nadat zij door het personeel op de hoogte gesteld zijn van het vrijwillig vertrek.

FIGUUR 3.4 Percentage bedrijven dat proactief vacatures opende, naar ontstaansreden van vacatures, 2012-2013

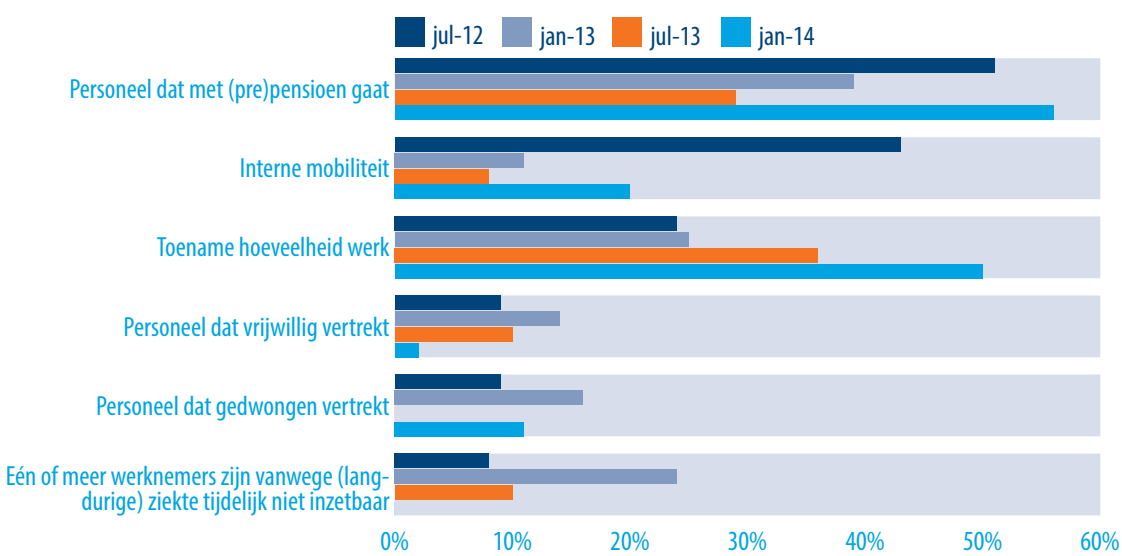

Bron: ROA, Arbeidsmarktmonitor Metalektro, 2013

\subsection{Externe bureaus nog altijd meest effectieve wervingskanalen}

Figuren 3.5 en 3.6 geven voor verschillende functiecategorieën weer wat voor bedrijven in de Metalektro in 2013 de meest effectieve wervingskanalen waren. Figuur 3.5 gaat in op de wervingskanalen voor uitvoerende en ondersteunende technici en Figuur 3.6 gaat in op wervingskanalen voor leidinggevende technici en technisch opgeleide verkopers. Met name voor het aantrekken van uitvoerend technisch personeel, maar ook bij de zoektocht naar ondersteunend technisch personeel, geeft het grootste deel van de bedrijven de voorkeur aan het inschakelen van een uitzendbureau. Alle andere wervingskanalen blijven hierbij ver achter. Voor het werven van technisch opgeleide verkopers en leidinggevend technisch personeel ligt dit anders; Hiervoor gaat de voorkeur uit naar commerciële werving- en selectiebureaus en het internet, waarbij wervingen selectiebureaus bovenaan eindigen. 
FIGUUR 3.5 Meest effectieve wervingskanalen voor uitvoerende en ondersteunende technici (\% bedrijven), 2013

$$
\text { Uitvoerend technisch personeel _ Ondersteunend technisch personeel }
$$

Via uitzendbureau

Via eigen personeel in deze bedrijfsvestiging

Via detacheringsbureau

Via advertentie in regionaal dagblad

Via externe relaties

Via commercieel werving- en selectiebureau

Via informele kanalen

Via internet

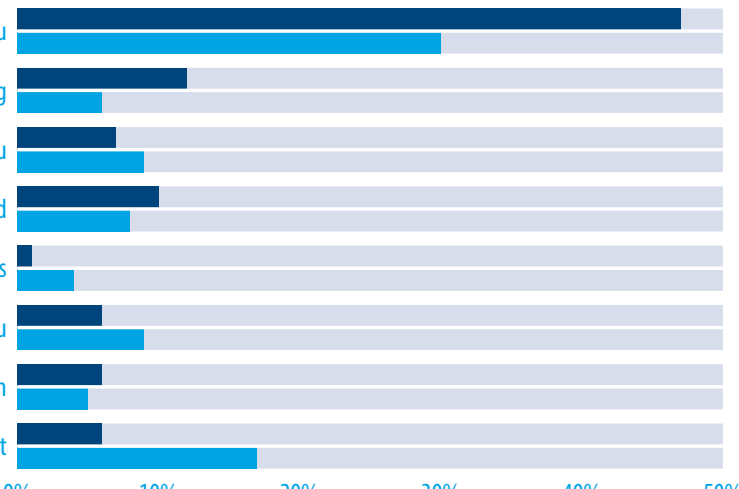

$0 \%$

$10 \%$

$20 \%$

$30 \%$

$40 \%$

$50 \%$

Bron: ROA, Arbeidsmarktmonitor Metalektro, 2013

Noot: De navolgende wervingskanalen zijn eveneens als antwoordcategorie opgenomen, maar worden door minder dan $5 \%$ van de bedrijven genoemd: via externe relaties, via personeel in de andere bedrijfsvestiging(en), via open sollicitaties, via UWV WERKbedrijf (voormalig CWI), via school/opleiding, via advertentie in vakblad en via advertentie in landelijk dagblad.

FIGUUR 3.6 Meest effectieve wervingskanalen voor leidinggevende technici en technisch opgeleide verkopers (\% bedrijven), 2013

Leidinggevend technisch personeel

Technisch opgeleide verkopers

Via commercieel werving- en selectiebureau

Via internet

Via informele kanalen

Via detacheringsbureau

Via eigen personeel in deze bedrijfsvestiging

Via advertentie in regionaal dagblad

Via externe relaties

Via uitzendbureau

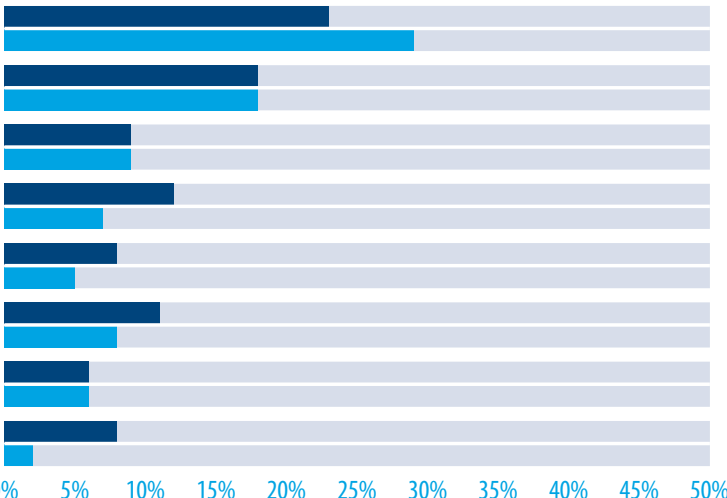

Bron: ROA, Arbeidsmarktmonitor Metalektro, 2013

Noot: De navolgende wervingskanalen zijn eveneens als antwoordcategorie opgenomen, maar worden door minder dan 5\% van de bedrijven genoemd: via personeel in de andere bedrijfsvestiging(en), via open sollicitaties, via UWV WERKbedrijf (voormalig CWI), via school/opleiding, via advertentie in vakblad en via advertentie in landelijk dagblad. 
Het internet wordt in 2012 voor alle hierboven besproken functiecategorieën vaker dan in voorgaande jaren als meest effectieve wervingskanaal genoemd. Dit toont Figuur 3.7. Het sterkst in opmars is het internet ten aanzien van werving voor ondersteunende technici maar ook voor de andere functiecategorieën geldt dat internet in 2013 weer even vaak als meest effectieve wervingskanaal werd genoemd als in 2008, toen de crisis net was uitgebroken. Tijdens de diepste crisisjaren werd het internet minder vaak als meest effectieve wervingskanaal omgeschreven. Over een eventueel verband is het evenwel moeilijk speculeren.

FIGUUR 3.7 Internet als meest effectieve wervingskanaal genoemd (\% bedrijven), naar technische functiecategorie, 2008-2013

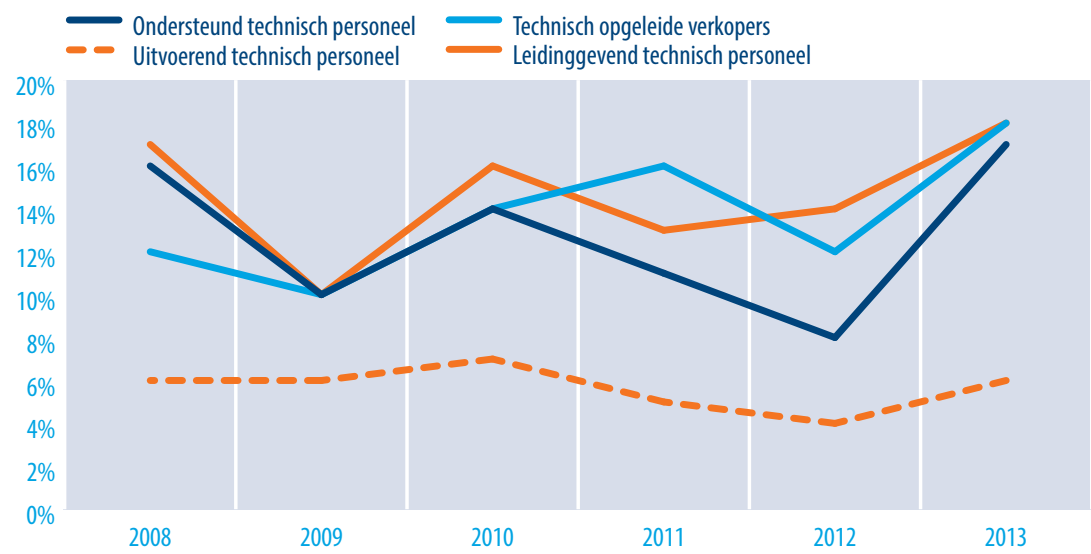

Bron: ROA, Arbeidsmarktmonitor Metalektro, 2007-2013

\subsection{Minder bedrijven met wervingsproblemen in 2013}

Figuur 3.2 toonde al dat er in 2013 minder vacatures waren die (erg) lang open stonden in de Metalektro. Dit impliceert dat er door de bedrijven minder wervingsproblemen worden ervaren. Deze vraag is ook direct aan de deelnemende bedrijven voorgelegd en de resultaten daarvan tonen we in Figuur 3.8. Het percentage bedrijven dat (erg) veel problemen ervaart bij het werven van technisch personeel is in 2013 inderdaad kleiner geworden dan in 2012 en is zelfs een fractie kleiner dan in 2011. Het percentage bedrijven dat geen of nauwelijks problemen ervaart is daarentegen voor het derde jaar op rij gestegen en het percentage dat 'gemiddeld' problemen ervaart is licht gedaald. Dit bevestigt het beeld uit Figuur 3.2, dat meer vacatures snel vervuld werden en voor weinig problemen zorgden en dat er minder langdurige problematische vacatures waren in 2013. 
FIGUUR 3.8 Problemen bij het vinden van technisch personeel (\% bedrijven), 2008-2013

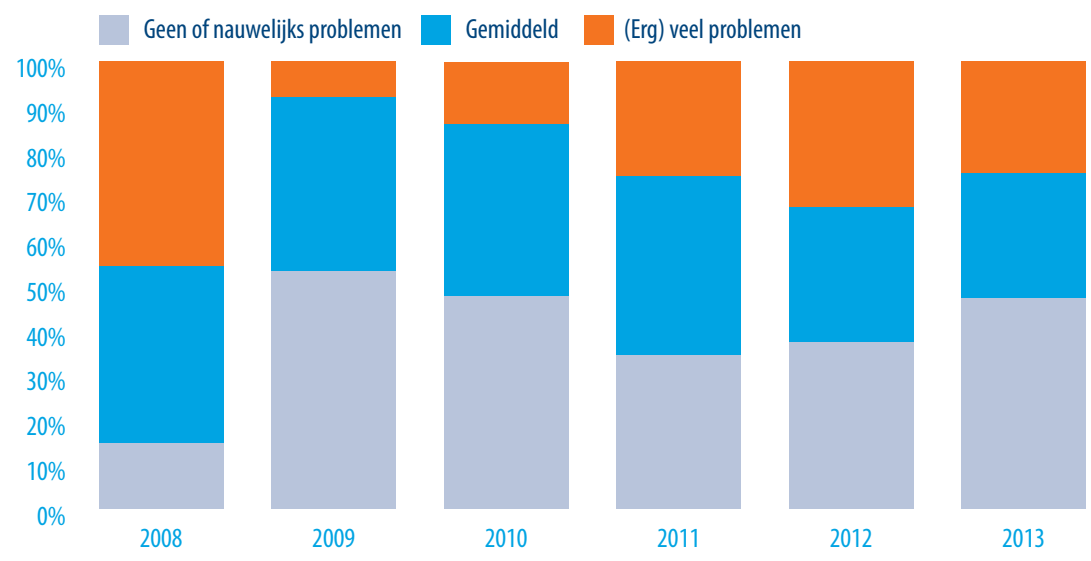

Bron: ROA, Arbeidsmarktmonitor Metalektro, 2008-2013

In de Figuren 3.9 en 3.10 gaan we dieper in op die bedrijven die aan hebben gegeven gemiddeld, veel of erg veel problemen te hebben bij het vinden van technisch personeel. De bedrijven die geen of nauwelijks problemen hadden bij het werven van technici zijn buiten beschouwing gelaten. Om meer te weten te komen over de wervingsproblemen die wel werden ervaren, maken we daarbij een verbijzondering naar verschillende typen technische personeel (3.9) en daarna breiden we dit voor 2013 uit met een verbijzondering naar regio (3.10).

Uit Figuur 3.9 blijkt dat voor alle technische functiecategorieën geldt dat in 2013 minder bedrijven wervingsproblemen ondervonden. De daling in wervingsproblemen beperkt zich dus niet tot specifieke functies. Voor de meeste functiecategorieën daalt het percentage bedrijven met wervingsproblemen zelfs al twee jaar op rij, met uitzondering van de ondersteunende technici. Engineering en R\&D personeel is in 2013 voor het eerst als aparte functiecategorie onderscheiden bij dit thema en hierbij ervaren minder bedrijven problemen dan bij het werven van uitvoerende technici. Ondanks een dalende trend voor alle functiecategorieën, geeft nog altijd de helft van de bedrijven met gemiddeld of (erg) veel wervingsproblemen aan dat dit (onder meer) uitvoerende technici betrof. Voor technisch opgeleide verkopers ligt dit in 2013 nog maar op $7 \%$ en voor de overige functiecategorieën tussen de $20 \%$ en $30 \%$.

Figuur 3.10 laat een aantal accentverschillen zien tussen de bedrijven met wervingsproblemen in verschillende regio's. Het meest opvallend is dat de wervingsproblemen in regio Noord/Oost veel minder vaak dan in de andere regio's betrekking hebben op uitvoerende technici en ze in Noord/Oost juist relatief vaker moeite hebben met het vinden van engineering en R\&D personeel. Ook in het Zuiden heeft men relatief vaker moeite met het vinden van engineering en R\&D personeel en tevens relatief het meeste moeite met het vinden van uitvoerende technici. Het Westen zit voor de meeste functiecategorieën tussen het Zuiden en het Noord/Oosten in 
en lijkt daarmee nog het meest op het landelijk gemiddelde, al heeft men in het Westen relatief iets meer moeite met het vinden van technisch opgeleide verkopers.

FIGUUR 3.9 Percentage bedrijven met problemen bij het vinden van technici, naar functiecategorie, 2007-2013
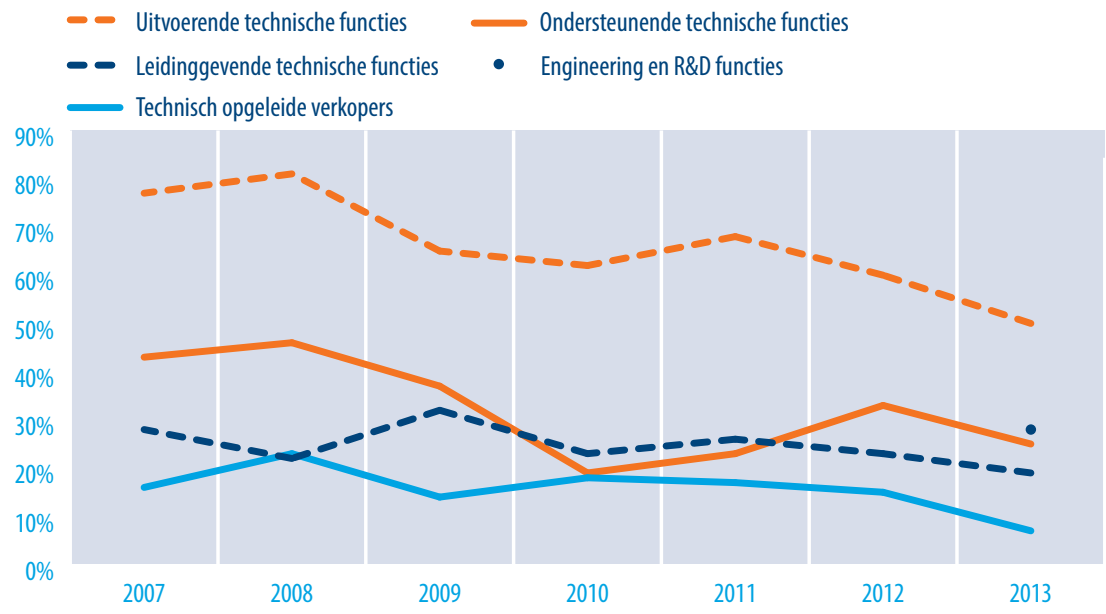

Bron: ROA, Arbeidsmarktmonitor Metalektro, 2007-2013

FIGUUR 3.10 Percentage bedrijven met problemen bij het vinden van technici, naar regio en functiecategorie, 2013

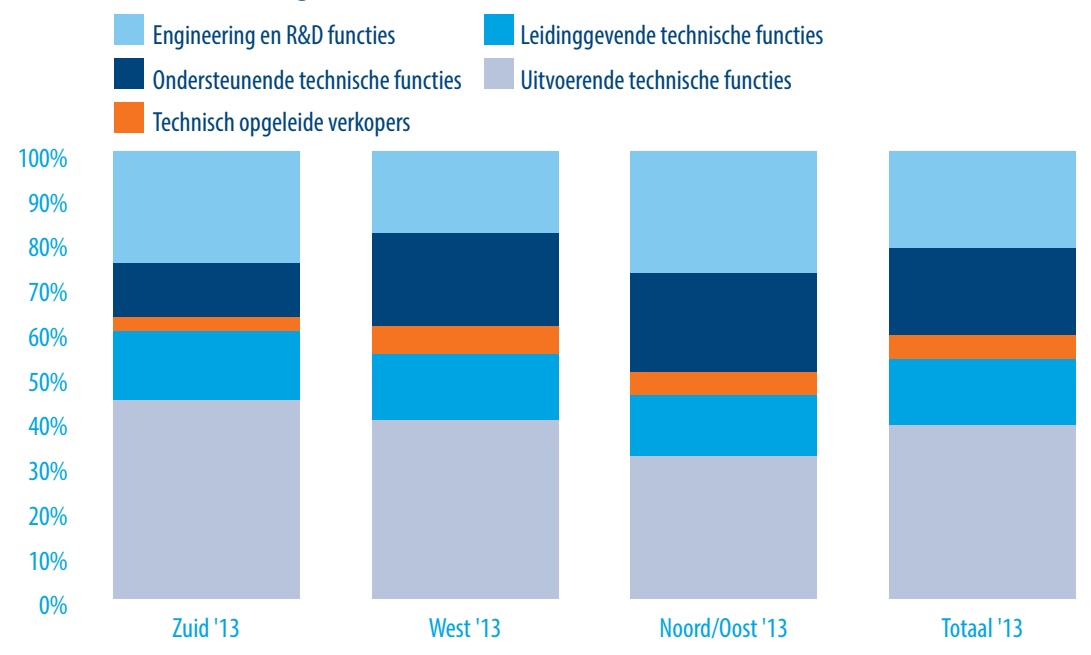

Bron: ROA, Arbeidsmarktmonitor Metalektro, 2013 


\subsection{Voornaamste oorzaken en gevolgen van wervingsproblemen weinig veranderd}

Figuur 3.11 laat zien dat de door de bedrijven genoemde oorzaken voor de wervingsproblemen al jaren min of meer hetzelfde zijn. Sinds 2011 wordt al jaren het meest genoemd dat sollicitanten niet de juiste competenties hebben, op afstand gevolgd door te weinig aanbod van sollicitanten en onvoldoende werkervaring van sollicitanten. De oorzaak 'te weinig aanbod vanuit opleidingen' groeide in 2013 gestaag door en wordt inmiddels door iets meer dan een vijfde van de bedrijven genoemd. Te hoge salariseisen van sollicitanten werd in 2013 minder vaak genoemd dan in de voorgaande jaren, wat er wellicht op duidt dat sollicitanten als gevolg van de langdurig aanhoudende crisis en stijgende werkloosheid wat minder eisen zijn gaan stellen.

FIGUUR 3.11 Belangrijkste oorzaken van de wervingsproblemen voor technici, 2010-2013

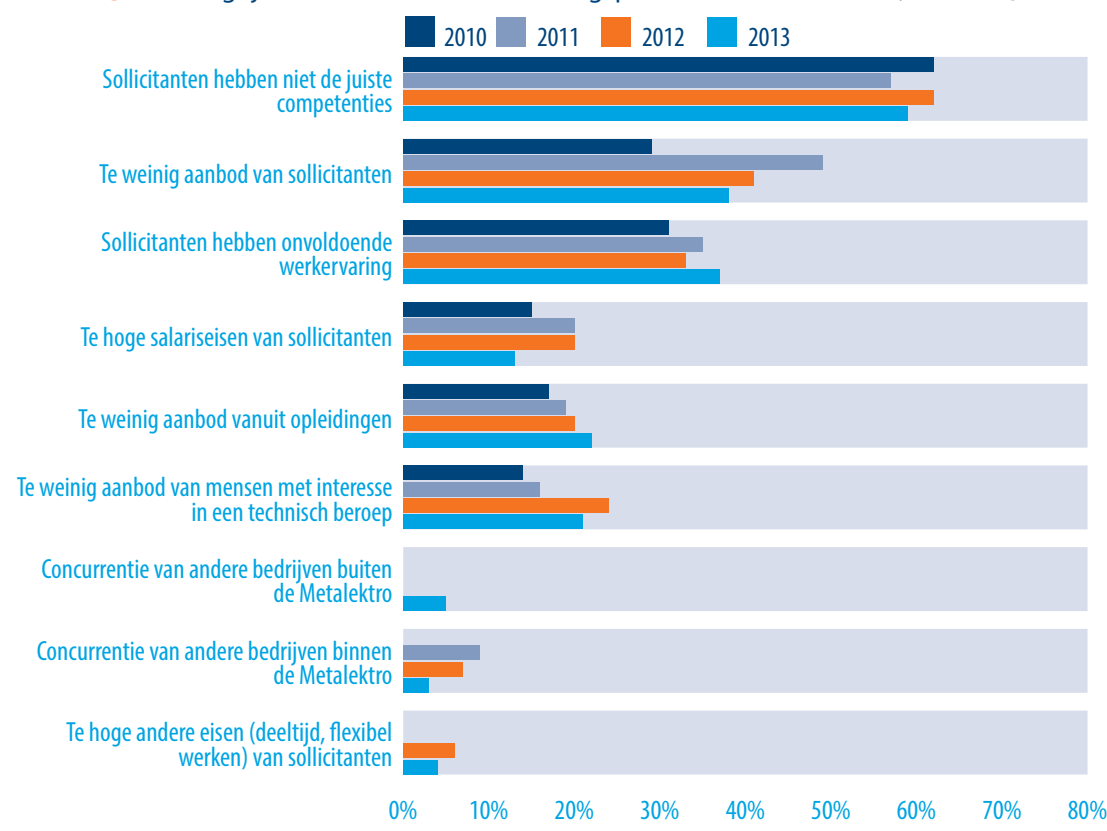

Bron: ROA, Arbeidsmarktmonitor Metalektro, 2010-2013 
Bij Toyota Material Handling ervaart men met name het werven van sales mensen als moeizaam, vertelt Frans Kalkhoven, HR manager. Sales mensen zijn volgens hem over het algemeen heel honkvast. "Op dit moment (januari 2014) staan er drie vacatures voor technisch opgeleide verkopers open. Deze staan al driekwart jaar open, zelfs na samenwerking met werving en selectiebureaus. Er kwamen wel kandidaten, maar niet de juiste. Het profiel dat we voor deze mensen voor ogen hebben is nu verder aangescherpt. Technische kennis is geen vereiste, technische affiniteit wel. We zijn op zoek naar mensen met een zekere mate van maturiteit (liefst ouder dan 30) die minimaal MBO - liefst HBO - opgeleid zijn. Wanneer blijkt dat we deze mensen niet kunnen aantrekken zullen we de mogelijkheden bekijken om zelf mensen op te leiden. Hierbij valt te denken aan 'campus-recruiting', waarbij mensen nog in de collegebanken worden benaderd en geïnteresseerd voor een baan bij het bedrijf."

Aggie van Baal, HR manager van WP Haton, noemt vooral $\mathrm{MBO}+$ gediplomeerde assemblagemonteurs moeilijk om binnen te halen. "Zij geven vaak de voorkeur aan doorleren". Ook monteurs die zowel WTB als elektro beheersen zijn moeilijk te vinden. “Dat komt ook doordat zij aan een groot aantal criteria moeten voldoen, zij moeten het manusje van alles zijn, moeten kunnen leidinggeven en managen en flexibel zijn." Mevrouw van Baal wijst op het blijvende belang om jongeren warm te maken voor de techniek en noemt hierbij ook de rol van de ouders. “We willen hen laten zien dat het werken hier uitdagend is en bovendien dat werken in een fabriek ook heel schoon is. Onlangs hebben we een elektrische auto gebouwd (in het kader van de Electric Sports Car Build-0ff 2012-2013). Door middel van een prijsvraag hebben we vijf ritten in de auto verloot. Dit is een leuke manier om jongeren te enthousiasmeren."

Bij Mayfran International B.V. ervaart men geen operationele gevolgen van tekorten in de techniek. Dit komt door gebruik te maken van het internationale karakter c.q. wervingsmogelijkheden van het bedrijf, aldus Harrie van der Heijden. Sinds 1999 is Mayfran proactief en structureel ook in het buitenland personeel gaan werven. Toen heeft men bijvoorbeeld 15 arbeidskrachten voor banen op uitvoerend niveau in Duitsland geworven, waarvan er vier nog altijd bij het bedrijf werkzaam zijn. Deze mensen zijn onder meer op job-beurzen in voormalig 0ost-Duitsland benaderd. Deze aanpak werkt tot op de dag van vandaag.

Ook bij Royal Duyvis Wiener ervaart men schaarste in bepaalde richtingen, met name HBO werktuigbouwkunde en elektrotechniek, vertelt Hilda Kluessien, HR manager. "Het is bijvoorbeeld heel erg moeilijk om een goede E\&l engineer te vinden. Toen ik onlangs naar zo iemand op zoek was heb ik er een hunter op gezet; dat gaat tegenwoordig internationaal. Uiteindelijk hebben we een Hongaar aangenomen".

Nog een ander bedrijf in de Metalekto geeft aan dat ze, ondanks dat ze krimpen in werkgelegenheid, toch onvervulde vraag naar specifieke mensen hebben. Het gaat dan om engineers op HBO niveau en monteurs op MBO niveau. "We zoeken allemaal het schaap met de vijf poten, maar die zijn schaars en als je ze al vindt komen ze van andere bedrijven en hebben veel eisen. Techneuten gaan niet voor 100 euro meer salaris van baan wisselen". 
TABEL 3.1 Top 5 gevolgen van niet-ingevulde vacatures, 2010-2013

\begin{tabular}{|c|c|c|c|c|}
\hline $\begin{array}{l}\text { Top } 5 \\
\text { per jaar }\end{array}$ & 2010 & 2011 & 2012 & 2013 \\
\hline 1 & $\begin{array}{l}\text { Toegenomen werkdruk } \\
(79 \%)\end{array}$ & $\begin{array}{l}\text { Toegenomen werkdruk } \\
(88 \%)\end{array}$ & $\begin{array}{l}\text { Toegenomen werkdruk } \\
(70 \%)\end{array}$ & $\begin{array}{r}\text { Toegenomen werkdruk } \\
(70 \%)\end{array}$ \\
\hline 2 & $\begin{array}{l}\text { Werk blijft liggen/deadlines } \\
\text { gemist }(47 \%)\end{array}$ & $\begin{array}{l}\text { Werk blijft liggen/deadlines } \\
\text { gemist ( } 45 \%)\end{array}$ & $\begin{array}{l}\text { Werk blijft liggen/deadlines } \\
\text { gemist (47\%) }\end{array}$ & $\begin{array}{r}\text { Werk blijft liggen/deadlines } \\
\text { gemist (53\%) }\end{array}$ \\
\hline 3 & $\begin{array}{l}\text { Levertijden worden langer } \\
(31 \%)\end{array}$ & $\begin{array}{l}\text { Hogere kosten doordat werk } \\
\text { moet worden uitbesteed } \\
(29 \%)\end{array}$ & $\begin{array}{l}\text { Hogere kosten doordat werk } \\
\text { moet worden uitbesteed } \\
(28 \%)\end{array}$ & $\begin{array}{r}\text { Levertijden worden langer } \\
\qquad(32 \%)\end{array}$ \\
\hline 4 & Verlies aan orders (21\%) & $\begin{array}{l}\text { Hogere wervings- of } \\
\text { opleidingskosten (24\%) }\end{array}$ & Verlies aan orders $(25 \%)$ & $\begin{array}{r}\text { Minder mogelijkheden om } \\
\text { te innoveren }(31 \%)\end{array}$ \\
\hline 5 & $\begin{array}{l}\text { Vermindering van de } \\
\text { kwaliteit van de productie/ } \\
\text { Hogere kosten doordat werk } \\
\text { moet worden uitbesteed } \\
(16 \%)\end{array}$ & $\begin{array}{l}\text { Levertijden worden langer } \\
(20 \%)\end{array}$ & $\begin{array}{l}\text { Vermindering van de } \\
\text { kwaliteit van de productie } \\
(22 \%)\end{array}$ & $\begin{array}{r}\text { Hogere kosten doordat werk } \\
\text { moet worden uitbesteed } \\
(23 \%)\end{array}$ \\
\hline
\end{tabular}

Bron: ROA, Arbeidsmarktmonitor Metalektro, 2010-2013

Ondanks dat de wervingsproblemen in 2013 over de hele linie zijn gedaald zijn er nog altijd wel vacatures die lang open staan en niet (op afzienbare termijn) ingevuld kunnen worden. De vijf voornaamste gevolgen die dit heeft zijn voor de afgelopen jaren weergegeven in Tabel 3.1. Net als in voorgaande jaren leiden niet-ingevulde vacatures in de eerste plaats tot toegenomen werkdruk en in de tweede plaats tot werk dat blijft liggen / gemiste deadlines. Het percentage bedrijven dat aangeeft dat werk blijft liggen / men deadlines mist stijgt daarbij licht tot $53 \%$. Op de derde plaats staan langere levertijden als gevolg van niet-ingevulde vacatures. Dit stond ook in 2010 al eens op de derde plaats en in 2011 op de vijfde plaats, maar ontbrak in 2012. Helemaal nieuw in de top vijf is dat bijna een derde van de bedrijven, die niet-ingevulde vacatures heeft, aangeeft dat dit ten koste gaat van de mogelijkheden om te innoveren. In Figuur 3.9 zagen we al dat engineering en R\&D personeel op de tweede plaats kwam als functiecategorie waar bedrijven voornamelijk wervingsproblemen voor ervaren. Als we er vanuit gaan dat het engineering/R\&D personeel normaal gesproken de drijvende kracht achter innovatie binnen de bedrijven is, dan zien we hier mogelijk het gevolg van moeilijk kunnen vinden van geschikte engineers/R\&D'ers. Helaas gaat de tijdreeks in Figuur 3.9 nog niet verder terug voor engineering/R\&D personeel waardoor we een eventueel verband niet formeel kunnen onderzoeken. Op de vijfde plaats in 2013 ervaren bedrijven hogere kosten doordat werk moet worden uitbesteed. De percentages in de top 5 tellen binnen een jaar niet op tot $100 \%$. Dat houdt in dat bedrijven dikwijls meerdere van deze gevolgen van niet-ingevulde vacatures ondervinden.

\subsection{Aanpassingen om moeilijk vervulbare vacatures op te vullen}

Welke aanpassingen in werving en selectie bedrijven het meeste maken om moeilijk vervulbare vacatures alsnog ingevuld te krijgen en of deze aanpassingen als effectief worden beschouwd, is af te lezen uit Figuur 3.12. Op de horizontale as is te zien welk 
percentage bedrijven een bepaalde aanpassing toepast. Op de verticale as is te zien welk percentage van de bedrijven die een bepaalde aanpassing toepassen, dit als (zeer) effectief beschouwen.

FIGUUR 3.12 Aanpassingen in werving en selectie om met moeilijk vervulbare vacatures voor technici om te gaan (\% bedrijven), 2013

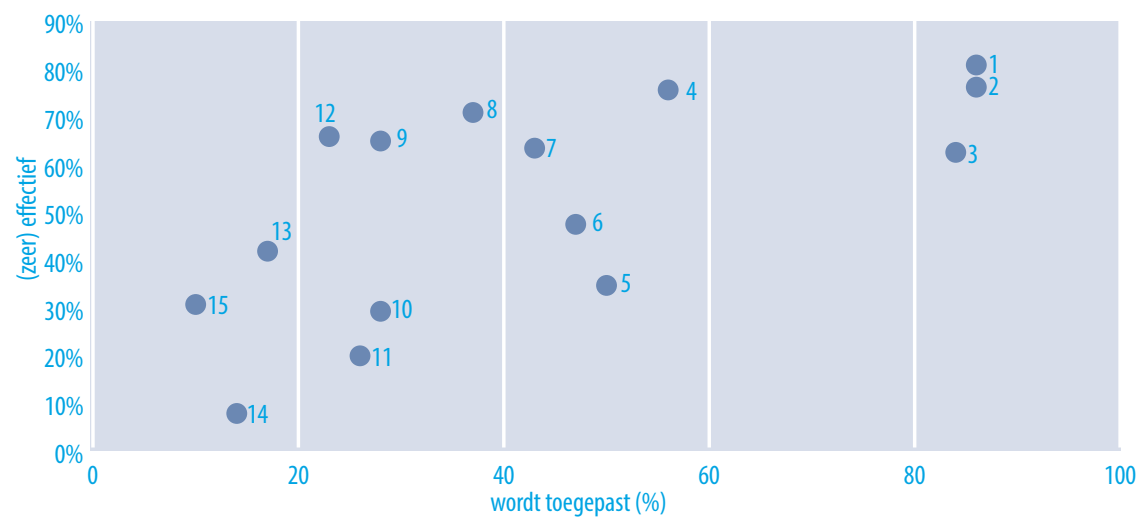

Bron: ROA, Arbeidsmarktmonitor Metalektro, 2013

Noot: 1 Bieden van goede loopbaanperspectieven

2 Inschakelen uitzendbureaus, commerciële werving- en selectiebureaus of detacheringsbureaus

3 Aantrekken van mensen met minder ervaring

4 Actiever benaderen van scholieren

5 Wervingsbonus voor het eigen personeel

6 Aantrekken van anders opgeleiden (andere richting)

7 Competentiegericht werven

8 Werven in het buitenland

9 Collegiaal inlenen van personeel

10 Aantrekken van lager opgeleiden (lager niveau)

11 Inschakelen UWV WERKbedrijf (voormalig: CWI)

12 Bieden van betere, CAO-overstijgende arbeidsvoorwaarden

13 Bieden van hoger salaris

14 Inschakelen bureau voor arbeidsmarktcommunicatie

15 Actiever benaderen van gedeeltelijk arbeidsongeschikten

Wat in 2013 maar liefst door $86 \%$ van de bedrijven met moeilijk vervulbare vacatures werd toegepast is het bieden van goede loopbaanperspectieven evenals het inschakelen van externe bureaus. Beide worden ook in hoge mate als effectief beschouwd. Het inschakelen van externe bureaus was altijd al een strategie die veel werd toegepast en effectief werd bevonden, maar het bieden van goede loopbaanperspectieven werd in 2012 nog maar door $62 \%$ van de bedrijven toegepast en is dus in populariteit 
sterk gestegen. Ook werd dit in 2013 als iets effectiever beoordeeld dan in 2012. Het aantrekken van mensen met minder ervaring werd door een iets groter percentage bedrijven toegepast als in 2012 maar werd in 2013 iets minder effectief beoordeeld dan in 2012. De laatste maatregel die in 2013 door meer dan de helft van de bedrijven werd toegepast is het actiever benaderen van scholieren (56\%). Dit wordt door driekwart van deze bedrijven als (zeer) effectief beoordeeld. De vier hierboven besproken maatregelen werden allen door meer dan de helft van de bedrijven met wervingsproblemen toegepast en eveneens door een ruime meerderheid daarvan (zeer) effectief bevonden. Dan zijn er nog de overige maatregelen. De helft van de bedrijven werkte met een wervingsbonus voor het eigen personeel, maar dit wordt maar door een derde van die bedrijven als effectief beschouwd. Vergeleken met de effectiviteit van de vier eerder genoemde maatregelen is dat niet veel. Alle overige maatregelen werden door minder dan de helft van de bedrijven met wervingsproblemen toegepast en voor een groot deel van die maatregelen geldt ook dat ze door relatief weinig van de bedrijven die ze toepasten effectief worden bevonden. Vier maatregelen die een relatief hoge mate van effectiviteit wordt toegedicht maar die relatief weinig werden toegepast zijn competentiegericht werven, werven in het buitenland, collegiaal inlenen van personeel en het bieden van betere, cao overstijgende arbeidsvoorwaarden. Ook in 2012 werden deze vier maatregelen relatief weinig toegepast maar tegelijkertijd wel in relatief hoge mate als effectief beoordeeld door de bedrijven die ze toepasten.

Naast de hierboven besproken aanpassingen in werving en selectie, kunnen bedrijven ook door middel van aanpassingen aan de interne bedrijfsvoering proberen een oplossing te vinden voor hun moeilijk vervulbare vacatures. Figuur 3.13 toont hoeveel procent van de bedrijven met moeilijk vervulbare vacatures gebruik heeft gemaakt van de genoemde interne aanpassingen en hoeveel procent van de bedrijven die een dergelijke aanpassing heeft toegepast deze als (zeer) effectief beoordeelt. In dezelfde rangorde als in 2012, vinden we als de vier meest toegepaste interne aanpassingen flexibele inzet, overwerk, om/bijscholen en werk anders organiseren. Alle vier scoren daarnaast vergelijkbaar als in 2012 op effectiviteit. Daarmee is overwerken nog steeds een populaire aanpassing om met moeilijk vervulbare vacatures om te gaan. Op de risico's van overwerken voor de duurzame inzetbaarheid van mensen werd ingegaan in de Agenda voor de Toekomst van juli 2013. Dit blijft een aandachtspunt met name op momenten dat er meer moeilijk vervulbare vacatures ontstaan, bijvoorbeeld als gevolg van een aantrekkende economie. Automatiseren staat zowel qua gebruik als effectiviteit op zo goed als dezelfde positie als in 2012. Uitbesteden in Nederland is daarentegen echter enkele procenten gestegen in gebruik en enkele procenten gedaald op beoordeelde effectiviteit, maar dit zijn geen grote verschuivingen. Uitbesteden naar het buitenland en productiebeperking werden, waarschijnlijk vanwege hun ingrijpende aard, in 2013 net zo weinig toegepast als in 2012 en het effectiviteitsoordeel van die bedrijven die dit wel deden was voor beide opties bijna 15 procentpunt lager dan in 2012. 
FIGUUR 3.13 Interne aanpassingen om met moeilijk vervulbare vacatures voor technici om te gaan (\% bedrijven), 2013

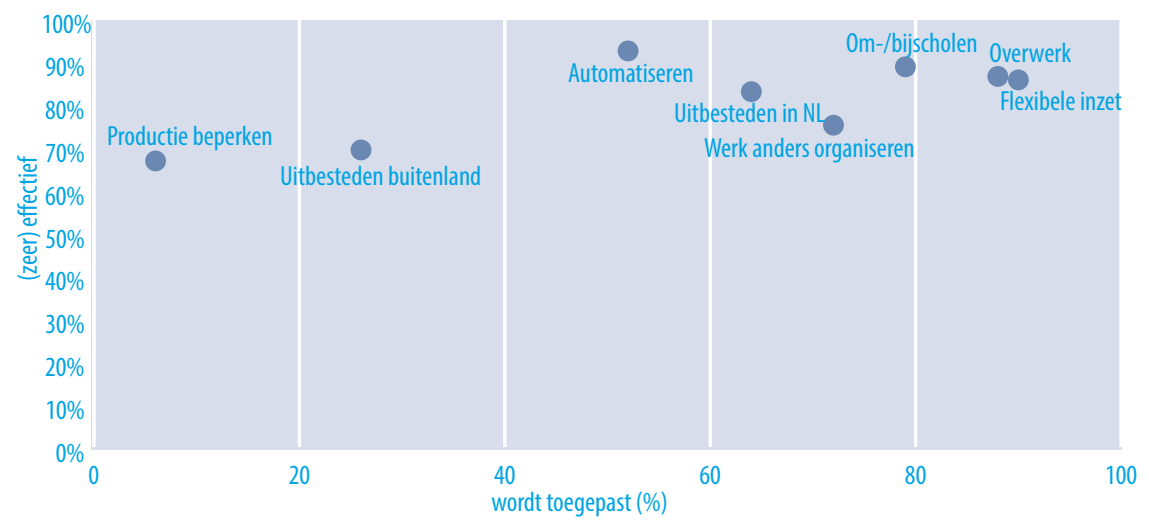

Bron: ROA, Arbeidsmarktmonitor Metalektro, 2013 



\section{4 COMPETENTIES EN OPLEIDINGSINSPANNINGEN}

In 2013 kon voor het eerst een halt worden toegeroepen aan de in 2009 ingezette daling van de out of pocket kosten, als percentage van de loonsom, die aan training worden besteed. Een gemiddelde technische medewerker in de Metalektro volgde in 2013 2,5 dag aan cursussen en trainingen. Een belangrijke conclusie is dat technici in het MKB relatief even vaak vaktechnische trainingen volgden als technici die bij grote bedrijven werkzaam waren. Wel bestaan er tussen het MKB en grote bedrijven aanzienlijke verschillen in de mate van cursusdeelname op diverse andere terreinen. Verder blijkt dat in 2013 de trainingsdeelname van technici met een tijdelijk contract alsook van technici die ingeleend werden is toegenomen. Ook ondervond in 2013 een groter deel van de metalektrobedrijven geen belemmeringen bij de scholing van het technisch personeel dan in 2012. 


\subsection{0pleidingsbestedingen gestabiliseerd}

Een continu punt van aandacht voor zowel afzonderlijke metalektrobedrijven als de sector in het geheel is de kennisontwikkeling van haar medewerkers. Investeren in het kennisniveau van het personeel blijft één van de belangrijkste fundamenten voor het handhaven en verbeteren van de concurrentiepositie van bedrijven. Metalektrobedrijven gaven in 2013 gemiddeld evenveel als in 2012 uit aan directe kosten (out of pocket) voor trainingen en cursussen van technisch personeel (Figuur 4.1). Ook in 2013 was dit gemiddeld $1,3 \%$ van de loonsom. Sinds 2010 daalde dit percentage behoorlijk, dus het is een positieve ontwikkeling dat deze neerwaartse trend in 2013 halt hield. Dit percentage verschilt in 2013 niet significant voor het MKB en grote bedrijven. Dit in tegenstelling tot 2012 toen grote bedrijven nog een significant hoger percentage van de loonsom aan directe trainingskosten uitgaven dan bedrijven uit het MKB. Ook zijn er in 2013 geen significante regionale verschillen.

Gevraagd in aantal dagen, geven de bedrijven aan dat een technische werknemer in de Metalektro in 2013 gemiddeld 2,5 dag aan cursussen en trainingen genoot. Terwijl technici die werkzaam zijn in het MKB in 2013 gemiddeld 2,1 dagen aan cursus en training besteedden, was dit onder technici bij bedrijven groter dan 250 medewerkers gemiddeld 4,4 dagen. Regionaal gezien wijkt het gemiddeld aantal gevolgde trainingen niet significant af.

FIGUUR 4.1 Gemiddelde totale opleidingskosten per bedrijf (\% van de loonsom), 2004-2013

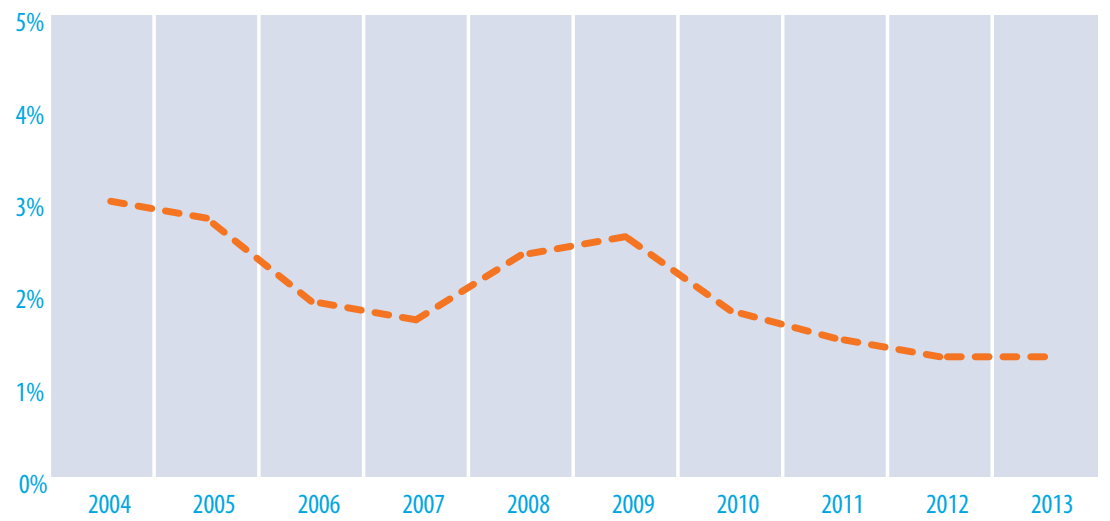

Bron: ROA, Arbeidsmarktmonitor Metalektro, 2004-2013

Al jaren blijkt het type dienstverband van technisch personeel van grote invloed op de trainingsdeelname. Figuur 4.2 geeft voor de periode 2010-2013 weer hoeveel procent van het technisch personeel per type dienstverband aan één of meerdere cursus(sen) heeft deelgenomen. Evenals in 2012, volgde in 2013 gemiddeld de helft (49\%) van het technisch personeel met een vast dienstverband minimaal één cursus of training. De 
trainingsdeelname van technici met een tijdelijk contract alsook van technici die ingeleend werden nam daarentegen duidelijk toe. Van alle personen met een tijdelijk dienstverband volgde in 2013 gemiddeld $40 \%$ minimaal één cursus. Dit is aanzienlijk hoger dan in 2011 en 2012. Ook het ingeleende personeel werd in 2013 relatief vaker getraind dan in 2012. In 2013 was dit $27 \%$, ten opzichte van $7 \%$ in 2012.5

FIGUUR 4.2 Gemiddelde trainings- en cursusdeelname van technisch personeel (\%) naar type dienstverband, 2010-2013

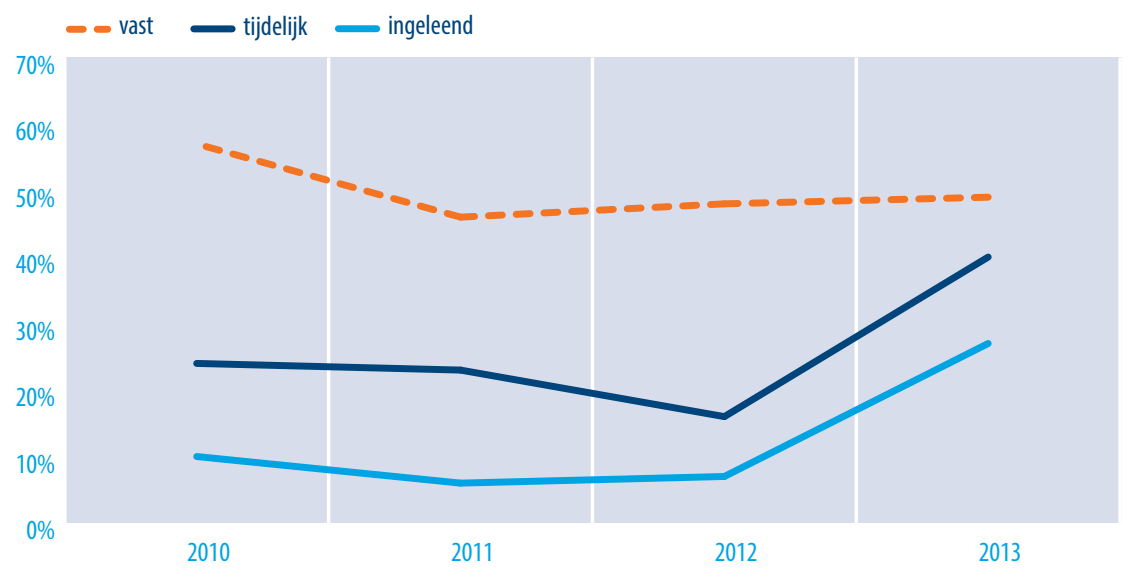

Bron: ROA, Arbeidsmarktmonitor Metalektro, 2010-2013

Figuur 4.3 laat de regionale verschillen zien in de trainingsdeelname van technische medewerkers. Hierbij wordt onderscheid gemaakt tussen personen in vaste loondienst en personen die behoren tot de flexibele schil (i.e. tijdelijke loondienst of ingeleend). Al jarenlang is hierbij in alle regio's een vast patroon terug te zien; medewerkers in vaste loondienst worden vaker getraind dan medewerkers in tijdelijke loondienst en laatstgenoemden worden op hun beurt vaker getraind dan ingeleende personen. In regio's Zuid en West is dit patroon in 2013 inderdaad opnieuw terug te zien, maar in regio Noord/Oost blijkt dit niet langer het geval. In het Noorden c.q. Oosten van het land volgden werknemers in vaste loondienst in 2013 in vergelijking met het landelijk gemiddelde aanzienlijk minder vaak een cursus (13\%-punt lager). Qua trainingsdeelname van werknemers in tijdelijke loondienst scoort het Noorden/Oosten in lijn met het landelijk gemiddelde. Onder ingeleend personeel ligt de trainingsdeelname dan weer iets boven het landelijk gemiddelde. Regio West doet het qua trainingsdeelname over de hele linie goed. De trainingsdeelname van alle drie de groepen is bovengemiddeld ten opzichte van het landelijke beeld, maar in het bijzonder hoog voor het personeel in vaste loon-

5 In de vragenlijst van meting 42013 is voor het eerst gebruik gemaakt van een schuifbalk (in plaats van een invulvak) waarmee respondenten op een schaal van o tot 100 kunnen aangeven hoeveel procent van hun technisch personeel met een specifiek dienstverband minimaal één cursus heeft gevolgd. In theorie is het mogelijk dat deze wijziging (een deel van) de gevonden resultaten verklaart. 
dienst (59\%). Dit beeld is tegenovergesteld aan de situatie in regio Zuid, waar in 2013 juist minder dan gemiddeld werd getraind. In laatstgenoemde regio is het met name de training van de flexibele schil die achterblijft. Zowel medewerkers in tijdelijke loondienst als ingeleende personen hebben in deze regio 10\%-punt minder vaak aan cursussen deelgenomen dan naar voren komt uit het landelijke beeld.

FIGUUR 4.3 Technisch personeel (\%) dat minimaal één cursus of training heeft gevolgd naar type dienstverband en regio, 2013

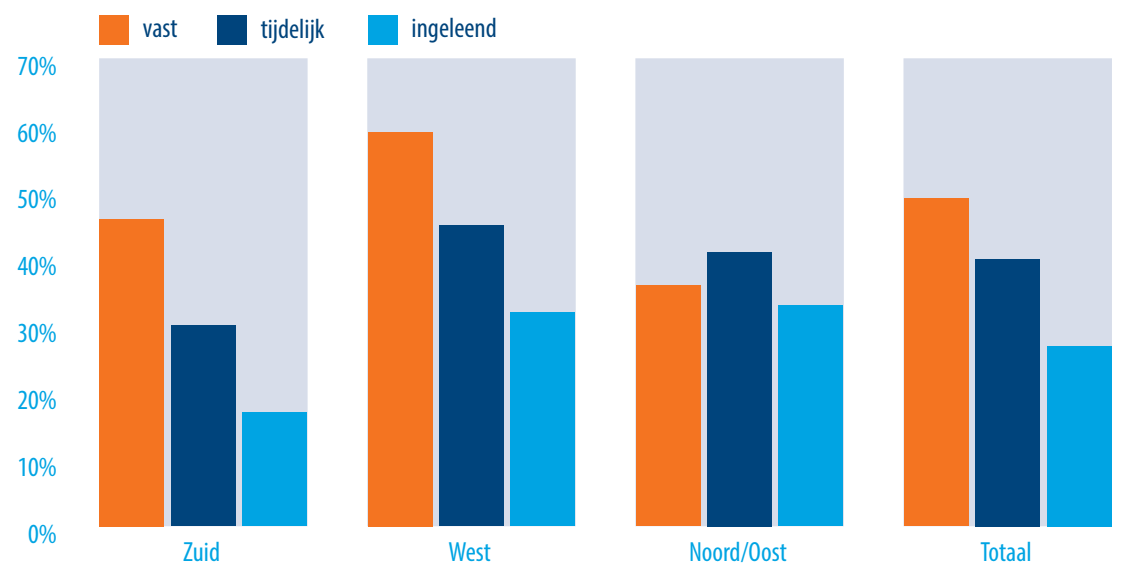

Bron: ROA, Arbeidsmarktmonitor Metalektro, 2013

\subsection{Initiatief voor trainingen en stimuleren van betrokkenheid personeel}

Figuur 4.4 laat middels een cirkeldiagram zien welke partij de metalektrobedrijven doorgaans als initiator aanduiden voor de deelname aan cursussen en trainingen van het technisch personeel in hun bedrijf. Het initiatief is evenals in 2012 in bijna de helft van alle gevallen vooral een gedeelde verantwoordelijkheid tussen de leidinggevende en de werknemer. Bij drie op de tien bedrijven in de Metalektro is hierbij doorgaans de belangrijkste rol weggelegd voor de direct leidinggevende. Verder is dit bij $12 \%$ van de bedrijven vooral de verantwoordelijkheid van de HR-/P\&O-afdeling, terwijl het kleinste deel (8\%) het initiatief tot cursusdeelname primair ziet als de verantwoordelijkheid van de werknemer zelf. Hierbij zijn er geen significante verschillen te ontwaren tussen grote bedrijven en het MKB. 


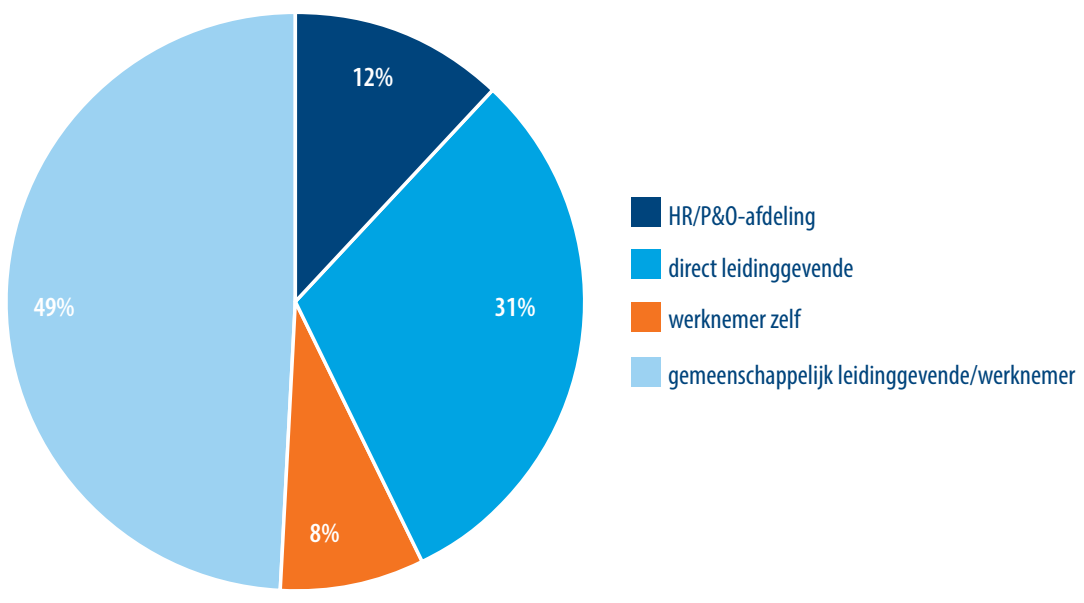

Bron: ROA, Arbeidsmarktmonitor Metalektro, 2013

Uit de voorgaande alinea bleek dat het initiatief voor de cursusdeelname van het technisch personeel in de meeste gevallen gemeenschappelijk genomen wordt door werkgever en werknemer samen. In het licht van de betrokkenheid van het technisch personeel bij de eigen ontwikkeling is het tevens een goed signaal dat het gros van de metalektrobedrijven gerichte activiteiten ontplooit om deze betrokkenheid bij haar medewerkers te stimuleren. Uit Figuur 4.5 blijkt dat slechts 14\% van de bedrijven in 2013 geen enkele actie heeft ondernomen om de betrokkenheid van technici bij de eigen ontwikkeling te stimuleren. Dit betekent echter dat de overige $86 \%$ dus wel één of meer activiteiten op dit vlak heeft ondernomen. Van alle werkgevers tracht het grootste deel om de betrokkenheid van technici bij de eigen ontwikkeling te stimuleren door hier extra aandacht aan te besteden tijdens functioneringsgesprekken. Dit wordt gedaan in zeven van de tien bedrijven in de Metalektro. Een andere veelgenoemde stimulans is dat aan leidinggevenden wordt geleerd om coachend leiding te geven. De helft van de bedrijven noemt dit. Andere activiteiten die elk door circa een derde genoemd worden zijn het aanbieden van een persoonlijk ontwikkelingsplan (POP), het doen van extra inspanningen door $\mathrm{P} \& \mathrm{O}$ en het trachten te creëren van spillover-effecten zodat werknemers elkaar onderling wijzen op het belang van opleiding en ontwikkeling. In vergelijking met 2012 valt vooral op dat in 2013 het stimuleren van coachend leiderschap door meer bedrijven wordt genoemd (+12\%-punt), evenals het leveren van extra inspanningen door de P\&O-afdeling (+9\%-punt). Vergelijken we grote bedrijven met het MKB, dan blijkt het aanbieden van een POP in het MKB minder gangbaar. Kleine en middelgrote bedrijven hebben deze activiteit significant minder vaak aangekruist dan grote bedrijven. Verder vindt in West-Nederland significant vaker overleg met het OR orgaan of de personeelsvertegenwoordiging plaats. 
FIGUUR 4.5 Activiteiten ter stimulering van betrokkenheid van technisch personeel bij eigen opleiding en ontwikkeling (\% bedrijven), 2013

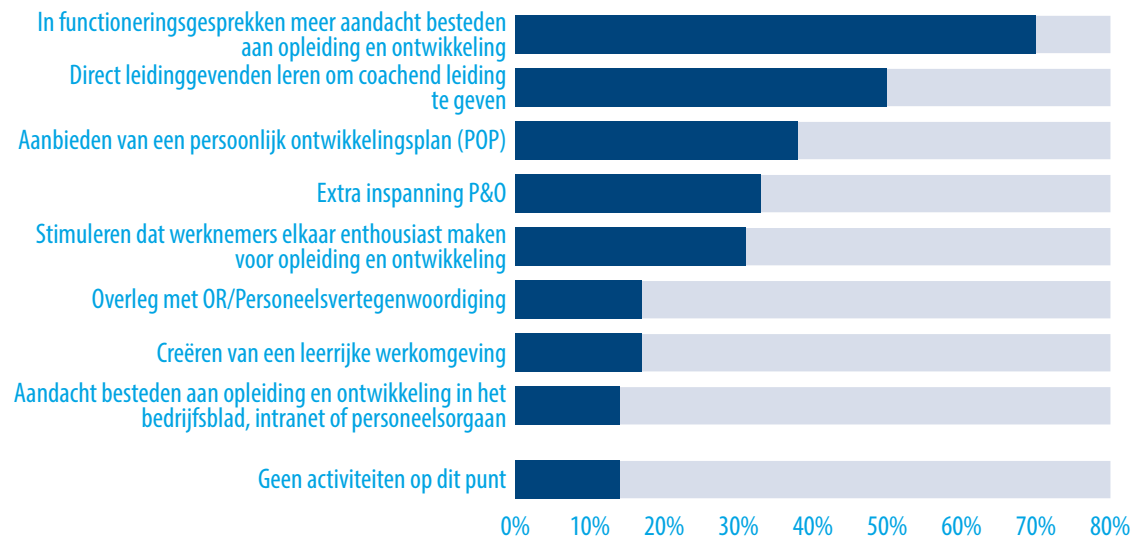

Bron: ROA, Arbeidsmarktmonitor Metalektro, 2013

Noot: Alleen de activiteiten die door ten minste 10\% van de werkgevers genoemd werden zijn in de figuur opgenomen.

\subsection{Meeste trainingen vaktechnisch of BHV/EHBO}

Een logische vervolgvraag na alle hiervoor besproken facetten op het gebied van cursussen en trainingen is: welk soort cursussen en trainingen volgde het technisch personeel in de Metalektro precies in 2013 ? Figuur 4.6 beantwoordt deze vraag. Technisch personeel volgde opnieuw het vaakst trainingen die gericht zijn op de ontwikkeling van vaktechnische vaardigheden. In bijna 9 van de 10 bedrijven nam het technisch personeel deel aan dergelijke cursussen. Dit is al jaren het meest voorkomende trainingsterrein. Vanzelfsprekend scoort ook de deelname aan BHV/EHBO-cursussen hoog. De top-5 in 2013 wordt vervolledigd door trainingen op het gebied van leidinggeven, ICT en veilig gedrag. Ten opzichte van 2012 is de deelname aan ICT-gerelateerde cursussen het meest toegenomen (+10\%-punt). Deze top- 5 ziet er overigens voor grote en MKB bedrijven hetzelfde uit. Een belangrijke conclusie is dat technici in het MKB relatief even vaak vaktechnische trainingen hebben genoten als technici bij grote bedrijven. Tussen beide groepen bestaat geen significant verschil. Wel bestaan er tussen het MKB en grote bedrijven aanzienlijke verschillen in de mate van cursusdeelname op diverse andere terreinen. MKB-bedrijven noemen in vergelijking met grote bedrijven bijvoorbeeld significant minder vaak dat technisch personeel heeft deelgenomen aan cursussen gericht op leidinggeven (61\%-punt minder), taalvaardigheden (48\%-punt minder), communicatieve vaardigheden en veilig gedrag (beide 37\%-punt minder). Dit is niet onlogisch want kleinere bedrijven hebben, naast minder personeel, vanzelf ook een kleinere diversiteit aan functies. Ook kennen grotere bedrijven doorgaans meer personeelsverloop waardoor er een grotere kans is dat er nieuwe medewerkers zijn ingestroomd die een training gaan volgen. 
FIGUUR 4.6 Terreinen waarop technisch personeel is getraind (\% bedrijven), 2012-2013

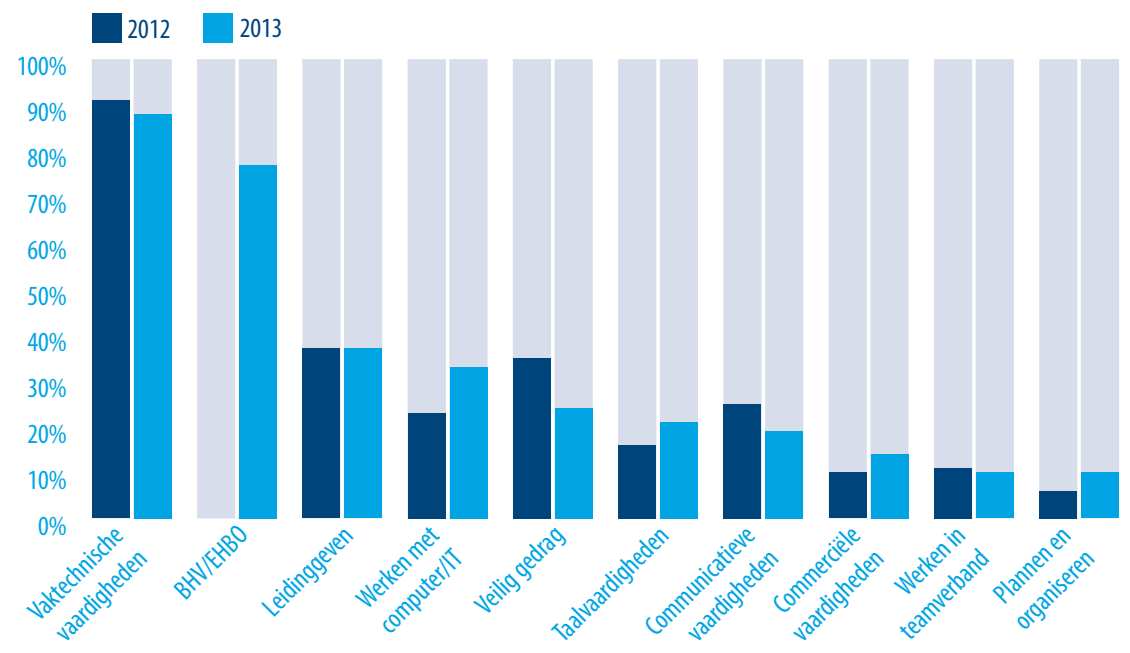

Bron: ROA, Arbeidsmarktmonitor Metalektro, 2012-2013

Noot: Alleen de cursusterreinen die in 2013 door ten minste 10\% van de werkgevers werden genoemd zijn opgenomen in de figuur.

Noot: BHV/EHBO werd in 2013 voor het eerst als aparte categorie onderscheiden.

Welke ontwikkelingen verwachten de bedrijven uit de Metalektro als het gaat om te volgen cursussen in de komende vijf jaar? Een kwart van de bedrijven verwacht dat de deelname aan vaktechnische cursussen de komende jaren zal toenemen ten opzichte van het al hoge niveau in 2013. Het overige deel van de bedrijven, driekwart, verwacht dat de deelname aan vaktechnische trainingen binnen nu en vijf jaar vrijwel gelijk zal blijven. Andere cursusterreinen die de komende jaren naar verwachting per saldo flink aan populariteit zullen winnen zijn: leidinggeven, veilig gedrag, communicatieve en commerciële vaardigheden. 
Soft skills en de PROFI competenties ${ }^{6}$ worden door verschillende bedrijven steeds belangrijker geacht, vaak omdat als gevolg van decentralisering leidinggevende verantwoordelijkheden op een steeds lager niveau komen te liggen en medewerkers steeds meer'ambassadeurs' van het bedrijf zijn.

Pratend over de toenemende eisen die gesteld worden aan bijvoorbeeld het vak van monteur, stelt Frans Kalkhoven, HR manager bij Toyota Material Handling B.V., de vraag hoe ver je moet gaan met het upgraden van het opleidingsniveau. “Technische skills van Hbo'ers zijn vaak niet afdoende. Mbo'ers beschikken dan weer vaak niet over organisatorische soft skills. $0 \mathrm{~m}$ deze reden is commerciële training ook voor onze monteurs van belang; zij dienen immers ook als visitekaartje van ons bedrijf. De monteurs die nu in dienst zijn hebben $\mathrm{MBO}$ niveau 3 à 4 . Zij moeten dus meer leren dan de competenties die zij in het $\mathrm{MBO}$ opdoen. Ze moeten hun werk zelfstandig organiseren en uitvoeren en correct omgaan met de klant. Deze skills horen dan ook bij het nieuwe profiel van onze monteurs". Door middel van trainingen worden deze soft skills geleerd bij Toyota Material Handling, naast training in vaktechnische vaardigheden.

\subsection{Tijd en geld nog altijd meest genoemde belemmeringen voor scholing/training}

Met het oog op het stimuleren van de cursusdeelname van technisch personeel in de toekomst is het interessant om niet alleen te focussen op de huidige cursussen die gevolgd worden, maar tevens te analyseren of er mogelijk sprake is van belemmeringen die de cursusdeelname in de weg staan. Immers, wanneer blijkt dat bepaalde belemmerende factoren bovengemiddeld vaak de cursusdeelname van technici in de weg staan, dan zou hier beleidsmatig op in gespeeld kunnen worden. Figuur 4.7 zet een breed scala aan factoren op een rij die de scholing van technisch personeel kunnen belemmeren. Bijna vier op de tien werkgevers ondervonden in 2013 geen enkele noemenswaardige belemmering bij de scholing van het technisch personeel. Een positieve ontwikkeling is dat dit een iets groter deel is dan in 2012 (34\%). In algemene zin wijkt het niveau van de afzonderlijke genoemde belemmeringen in 2013 echter weinig af ten opzichte van 2012. De twee vaakst genoemde obstakels in de ogen van werkgevers zijn evenals in $2011 \mathrm{en}$ 2012 dat cursussen veel tijd en geld kosten.

Opvallend is dat bedrijven die behoren tot het MKB significant vaker aangeven dat zij geen belemmeringen hebben ervaren dan grote bedrijven. Daarnaast noemt het MKB significant minder vaak dat cursussen veel geld kosten, dat de beschikbare cursussen niet aansluiten op het kennisniveau van het technisch personeel en dat cursussen niet aansluiten bij de dagelijkse praktijk van het bedrijf. Ook bestaan er enkele regionale verschillen. Zo geven bedrijven uit regio Noord/Oost significant vaker aan dat cursussen niet in de regio beschikbaar zijn, dat zij te kampen hebben met vervangingsproblemen als medewerkers op cursus gaan, dat cursussen veel tijd in beslag nemen en

6 Probleemoplossend vermogen, Relatie met klanten, Omgaan met veranderingen, Flexibiliteit, Initiatief. 
dat technisch personeel haar scholingswensen niet goed genoeg kenbaar maakt bij het management. Bedrijven die gevestigd zijn in regio West geven in vergelijking met beide andere regio's significant vaker aan dat technisch personeel vaak zelf niet geïnteresseerd is in het volgen van cursussen en dat taalproblemen een obstakel vormen dat cursusdeelname in de weg staat.

FIGUUR 4.7 Belemmeringen bij de scholing van het technisch personeel (\% bedrijven), 2013

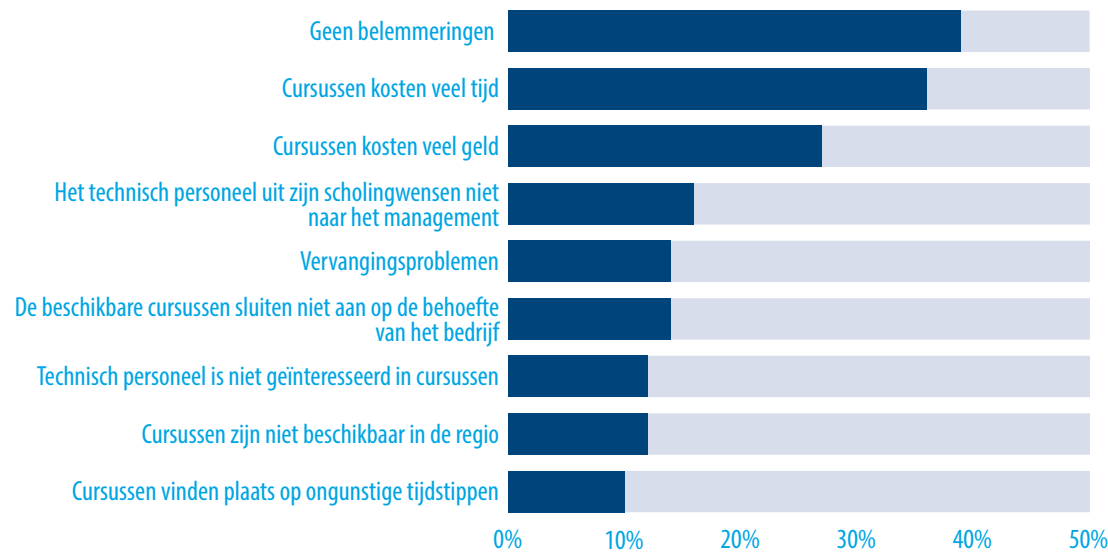

Bron: ROA, Arbeidsmarktmonitor Metalektro, 2013

Noot: Alleen de belemmeringen die door ten minste $10 \%$ van de werkgevers werden genoemd zijn opgenomen in de figuur.

Hoewel het logisch verklaarbaar is vanuit het perspectief van het individuele bedrijf, blijft een algemeen punt van aandacht voor de sector als geheel dat de trainingsdeelname ook in 2013 in verreweg de meeste gevallen gericht is op de huidige functie van de werknemers. Dit is het geval bij ruim driekwart van alle gevolgde cursussen (77\%). Daarnaast is $20 \%$ van de cursussen primair gericht op de verdere loopbaan binnen het eigen bedrijf. De overige 3\% bestaat uit cursussen die gericht zijn op de verdere loopbaan buiten het eigen bedrijf. Zeker vanuit het oogpunt van employability en een verhoogde pensioenleeftijd zou dit laatste punt extra aandacht verdienen. Het concept van employability gaat er immers van uit dat de baanzekerheid van werknemers bij de eigen werkgever niet het uitgangspunt moet zijn, maar dat dit in toenemende mate zou moeten verschuiven naar het creëren van werkzekerheid op de (technische) arbeidsmarkt. Wat dat betreft lijken metalektrobedrijven in regio Noord/Oost iets voor te lopen bij de rest van het land. Terwijl in het Zuiden en Westen respectievelijk 1,7\% en 2,1\% van de cursussen van het technisch personeel gericht is op de verdere loopbaan buiten het eigen bedrijf, is dit in het Noorden/Oosten, met 6,1\%, significant hoger. 


\subsection{HR-instrumenten die in 2013 zijn ingezet}

Om het loopbaanmanagement van medewerkers in goede banen te kunnen leiden maken metalektrobedrijven gebruik van diverse HR-instrumenten. Deze HR-instrumenten kunnen grofweg worden onderverdeeld in vier bredere categorieën die samen de loopbaanmanagementcyclus vormen:

(A) de bepaling van het huidige competentieniveau van het technisch personeel (assessment);

(B) het vastleggen van doelen en acties;

(C) het volgen van scholing;

(D) het opdoen van de gewenste werkervaring.

Figuur 4.8 geeft deze verschillende categorieën weer inclusief de daarbij behorende HR-instrumenten die bedrijven in kunnen zetten ten behoeve van de ontwikkeling van hun technisch personeel. Daarnaast worden in de figuur nog twee algemenere HR-instrumenten weergegeven die breder toepasbaar zijn. Loopbaanplanning en werkoverleggen kunnen in de praktijk namelijk doorlopend ingezet worden ter ondersteuning van alle vier onderscheiden categorieën van het loopbaanmanagement. De figuur geeft een overzicht van de in 2013 toegepaste HR-instrumenten en vergelijkt dit met 2012. Bedrijven in de Metalektro maakten in 2013 opnieuw veelvuldig gebruik van werkoverleggen ten behoeve van het loopbaan management van hun technisch personeel. Werkoverleggen werden vanuit dit perspectief ingezet in circa acht op de tien bedrijven. In vergelijking met het jaar ervoor werden werkoverleggen echter iets minder vaak genoemd. Aan concrete loopbaanplanning voor hun technisch personeel wordt in veel bedrijven naar eigen zeggen minder aandacht besteed. Bij 15\% van de bedrijven werd dit instrument ingezet voor de meerderheid van het technisch personeel en dit percentage is vergelijkbaar met het jaar ervoor.

\section{(A) Assessment}

Voor het vaststellen van het huidige competentieniveau van het technisch personeel blijkt vooral een beroep te worden gedaan op functionerings- en beoordelingsgesprekken. Functioneringsgesprekken worden in meer dan acht op de tien bedrijven in de Metalektro ingezet voor een meerderheid van het technisch personeel en beoordelingsgesprekken in bijna zeven op de tien bedrijven. Daarmee worden beide HR-instrumenten aanzienlijk vaker ingezet dan instrumenten als de erkenning van verworven competenties (EVC) en het gebruik van competentie- of vaardighedenmatrices. Daarbij geldt dat zowel de erkenning van verworven competenties als de inzet van competentie- of vaardighedenmatrices significant minder vaak worden ingezet door het MKB dan door grote bedrijven. 
FIGUUR 4.8 HR-instrumenten die werden ingezet voor de meerderheid van het technisch personeel, 2012-2013

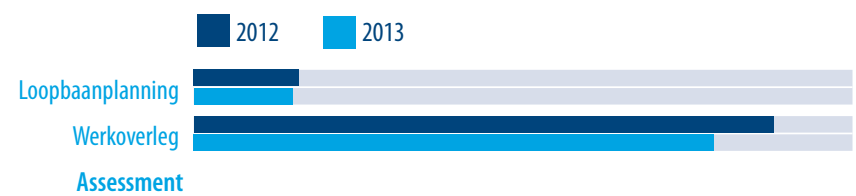

Functioneringsgesprekken

Beoordelingsgesprekken

Competentie- of vaardighedenmatrix

EVC

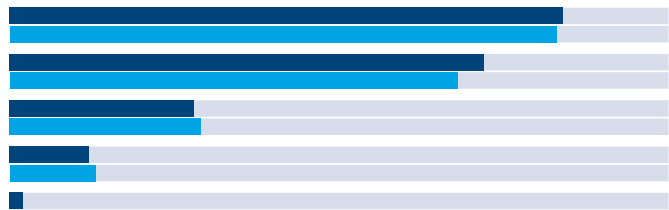

Loopbaanadvies- of mobiliteitscentrum

Vastleggen doelen en acties

Bedrijfsopleidingsplan (BOP)

Persoonlijk ontwikkelingsplan (POP)

Competentiemanagementsysteem

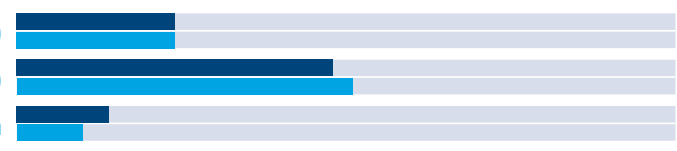

Scholing

Bedrijfsopleidingsbudget

Persoonlijk opleidingsbudget

Leren onder werktijd

Scholings/ontwikkelingsgesprekken

Werkervaring opdoen

Functieroulatie

Uitwisseling werknemers andere vestigingen

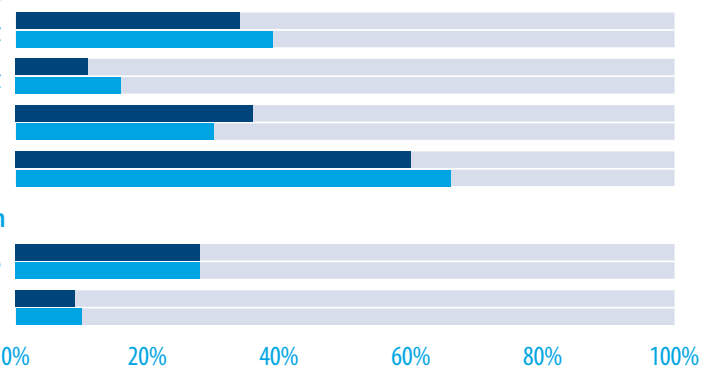

Bron: ROA, Arbeidsmarktmonitor Metalektro, 2012-2013

\section{(B) Vastleggen van doelen en acties}

Het vaststellen van doelen en acties draagt er tijdens het loopbaanmanagement toe bij dat er achteraf geen misverstanden kunnen bestaan over de afspraken die eerder overeengekomen zijn tussen werkgever en werknemer. De helft van alle bedrijven maakte in 2013 bij een meerderheid van het technisch personeel gebruik van een persoonlijk ontwikkelingsplan (POP) om doelen en acties vast te leggen. Een kwart van de bedrijven maakt gebruik van een bedrijfsopleidingsplan (BOP) en verder blijkt dat dit instrument significant vaker wordt ingezet door bedrijven met meer dan 250 medewerkers. De inzet van een competentiemanagementsysteem is het minst toegepaste HR-instrument om doelen en acties vast te leggen. 


\section{(C) Volgen van scholing}

Bij het faciliteren van de scholingsdeelname van het technisch personeel maken bedrijven veruit het meeste gebruik van scholings- en ontwikkelingsgesprekken. Twee op de drie metalektrobedrijven voerden deze gesprekken in 2013 met de meerderheid van hun technisch personeel. Bovendien is dit percentage nog ietwat gestegen ten opzichte van het niveau in 2012. Ook het percentage bedrijven dat bedrijfsopleidingsbudgetten en persoonlijke opleidingsbudgetten heeft ingezet is in 2013 toegenomen. Leren onder werktijd blijkt in 2013 juist iets te zijn afgenomen. Toch bieden in 2013 nog altijd drie op de tien bedrijven hun technische medewerkers de mogelijkheid om te leren onder werktijd. Dat dit percentage in 2013 is afgenomen hoeft niet automatisch negatief te zijn. Het is goed denkbaar dat, gegeven de positieve ontwikkeling van de omzet in 2013, werknemers weer voller bezet zijn en minder werktijd over houden om aan (formeel) leren te besteden.

\section{(D) Opdoen van de gewenste werkervaring}

De ontwikkeling van kennis en vaardigheden van het technisch personeel kan tevens gefaciliteerd worden door hen nieuwe werkervaring op te laten doen. Evenals in 2012 werd in 2013 bij bijna 30\% van de bedrijven gebruik gemaakt van functieroulatie. Werknemers kunnen ook leren van uitwisseling met collega's van andere bedrijfsvestigingen. Dit wordt echter in mindere mate toegepast. Dit lijkt voor de hand liggend omdat met name voor kleinere bedrijven geldt dat zij vaak maar op één plek gevestigd zijn. 


\section{5 \\ TECHNOLOGISCHE INNOVATIES EN ORGANISATORISCHE VERANDERINGEN}

Evenals in 2012 heeft ook in 2013 weer ongeveer 85\% van alle metalektrobedrijven één of meerdere technologische vernieuwingen doorgevoerd. Bedrijven verwachten de komende jaren nog meer te innoveren, zowel qua product-, proces- als dienstinnovaties. Daarnaast heeft iets meer dan de helft van de bedrijven in 2013 een organisatorische verandering doorgevoerd. Het ging hier meestal om het variabel inzetten van technisch personeel. Ongeveer drie kwart van de bedrijven geeft aan behoefte te hebben aan breed inzetbare uitvoerende technici, voornamelijk om schommelingen in de bedrijfsdrukte op te vangen en ter vervanging van afwezig personeel. Aan deze behoefte werd in 2013 in vrijwel alle bedrijven voldaan. De komende jaren worden nog meer organisatorische veranderingen verwacht, waaronder een sterke toename in de samenwerking met onderwijsinstellingen. 


\subsection{Toename verwacht in product-, proces- en dienstinnovaties}

Dit hoofdstuk begint met een beschrijving van de gerealiseerde en verwachte ontwikkelingen met betrekking tot technologische innovaties. Technologische innovaties kunnen betrekking hebben op producties, processen of diensten. Net als in 2012 heeft in 2013 ongeveer $85 \%$ van de bedrijven één of meerdere technologische innovaties doorgevoerd. De meeste innovaties waren wederom gericht op het sterk verbeteren van bestaande goederen (52\%) en methoden (39\%). Het minst werd geïnnoveerd op het gebied van diensten die nieuw zijn voor het bedrijf en de markt.

FIGUUR 5.1 Gerealiseerde en verwachte technologische innovaties (\% bedrijven)

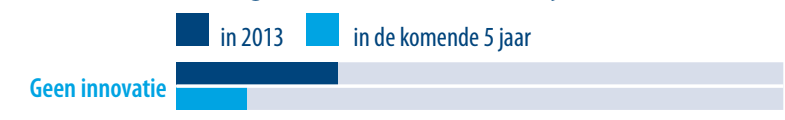

Productinnovatie:

Ontwikkeling van goederen die nieuw zijn voor de markt

Ontwikkeling van goederen die al op de markt zijn, maar nieuw zijn voor uw bedrif

Sterk verbeteren van goederen die uw bedrijf reeds aanbiedt

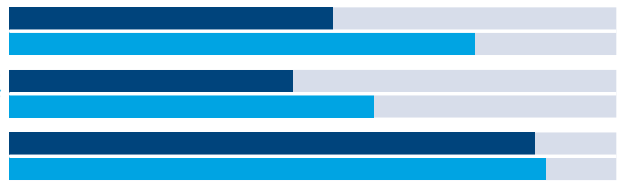

Dienstinnovatie:

Ontwikkeling van diensten die nieuw zijn voor de markt Ontwikkeling van diensten die al op de markt zijn, maar nieuw zijn voor uw bedrijf

Sterk verbeteren van diensten die uw bedrijf reeds aanbiedt

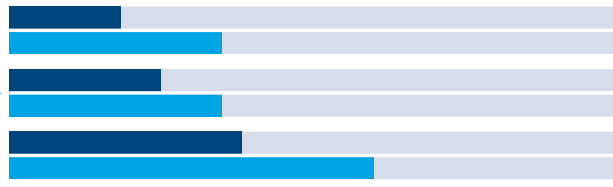

Procesinnovatie:

Ontwikkeling van nieuwe methoden voor de productie van goederen en diensten

Sterk verbeteren van reeds gebruikte methoden voor de productie van goederen en diensten

Ontwikkeling van nieuwe logistieke processen

Ontwikkeling van nieuwe methoden voor ondersteunendeactiviteiten voor uw processen

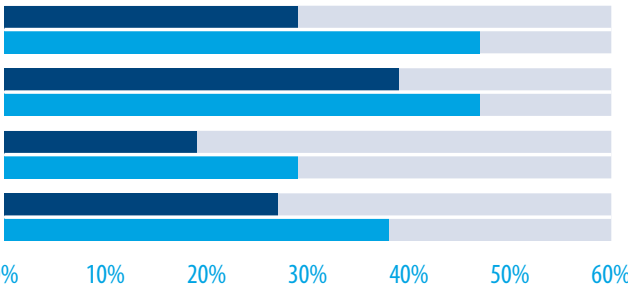

Bron: ROA, Arbeidsmarktmonitor Metalektro, 2013

Uit Figuur 5.1 blijkt bovendien dat bedrijven in de Metalektro de komende jaren duidelijk meer technologische innovaties verwachten dan in 2013 het geval was. Voor alle product-, proces- en dienstinnovaties wordt voor de komende vijf jaar een hoger percentage verwacht. Vaak betreft het een aanzienlijke toename. Bijna de helft van de bedrijven (47\%) verwacht de komende vijf jaar een nieuw product te ontwikkelen en/ of een nieuwe methode voor de productie van goederen en diensten te ontwikkelen. Deze verwachtingen zijn duidelijk positiever dan in 2012 toen slechts een kwart van 
de bedrijven dacht in 2013 een dergelijke innovatie door te voeren.7 Ook verwachten bedrijven een duidelijke toename in het aantal innovaties dat betrekking heeft op diensten. Slechts $7 \%$ van de bedrijven verwacht geen innovatie door te voeren in de komende vijf jaar.

\subsection{Organisatorische innovaties}

We bespreken drie verschillende organisatorische innovaties die in de Metalektro van belang zijn. Het betreft hier allereerst'organisatie en management'. Het gaat hierbij voornamelijk om vernieuwingen die betrekking hebben op de manier waarop het werk en de verantwoordelijkheden georganiseerd worden en hoe het bedrijf door het management wordt geleid. Een tweede belangrijke vorm van organisatorische innovaties zijn innovaties die betrekking hebben op het menselijk kapitaal van het bedrijf. Naast het verder ontwikkelen van het menselijk kapitaal door bijvoorbeeld het volgen van trainingen ${ }^{8}$ betreft het ook innovaties waardoor het menselijk kapitaal binnen bedrijven beter benut kan worden. Hiermee bedoelen we met name de inzetbaarheid van het personeel in de Metalektro. Een derde vorm van organisatorische innovaties zijn nieuwe vormen van samenwerking in de bedrijfsomgeving. Het kan hier gaan om allianties met andere bedrijven, samenwerking met leveranciers, klanten of kennisinstellingen.

TEKSTBOX 5.1 Organisatorische innovatie en technologische innovatie hand in hand

Bij WP Haton is de R\&D afdeling een paar jaar geleden afgeschaft, vertelt HR manager Aggie van Baal. Dit betekent niet dat er niet meer aan R\&D wordt gedaan. “Voorheen hadden we een ideeënbus; dat bleek niet te werken omdat de bedenker van het idee (bijvoorbeeld een monteur) dit opschreef in voor de ontvanger (HBO geschoold) onbegrijpelijke taal." In het 'blue innovation center' - dat in het midden van de fabriekshal staat - kunnen de medewerkers door middel van een whiteboard, schoolbord en machine rechtstreeks met elkaar communiceren en kan elke medewerker zijn suggesties en ideeën kwijt. “Het is een speeltuin voor iedereen. Nu hebben we dus 125 R\&D medewerkers."

\section{Minder organisatorische veranderingen bij stijgende omzet en vice versa}

In Figuur 5.2 is het percentage bedrijven te zien dat in 2013 een organisatorische verandering heeft doorgevoerd. lets minder dan de helft (46\%) van de bedrijven heeft in 2013 geen organisatorische verandering doorgevoerd. Een krappe meerderheid heeft dus minimaal één verandering doorgevoerd. De meeste bedrijven (22\%) geven aan dat zij een verandering hebben doorgevoerd met betrekking tot het variabel inzetten

7 In 2012 werd apart gevraagd naar verwachte investeringen in 2013 en in de periode 2014-2016. Terwijl 26\% (24\%) van de bedrijven van plan was een nieuw product (proces) te ontwikkelen in 2013 , was $16 \%$ (15\%) dit van plan in de periode van 2014-2016.

8 De manier waarop bedrijven investeren in het menselijk kapitaal van hun personeel wordt besproken in Hoofdstuk 4. 
van het eigen technisch personeel. Ook in 2012 was dit de meest doorgevoerde organisatorische verandering. Toen gaf echter nog $34 \%$ van de bedrijven aan een dergelijke organisatorische verandering te hebben doorgevoerd. Decentralisatie en het verminderen van het aantal managementlagen zijn veranderingen die in 2013 nauwelijks zijn doorgevoerd. Bedrijven geven aan deze twee organisatorische veranderingen ook in de toekomst niet veel te gaan toepassen. Dit heeft waarschijnlijk te maken met het hoge percentage bedrijven dat het aantal managementlagen tot 2011 heeft teruggebracht. $\mathrm{Er}$ is simpelweg weinig ruimte om het aantal managementlagen nog verder terug te brengen. Voor de komende jaren wordt met name aandacht besteed aan taakintegratie over afdelingen, het variabel inzetten van het eigen technisch personeel en de externe samenwerking. Maar liefst $38 \%$ van de bedrijven is van plan de komende vijf jaar met één of meerdere externe partijen te gaan samenwerken. Hoe de externe samenwerking er in de Metalektro nu voor staat en welke veranderingen bedrijven de komende vijf jaar voorspellen, wordt later in dit hoofdstuk besproken.

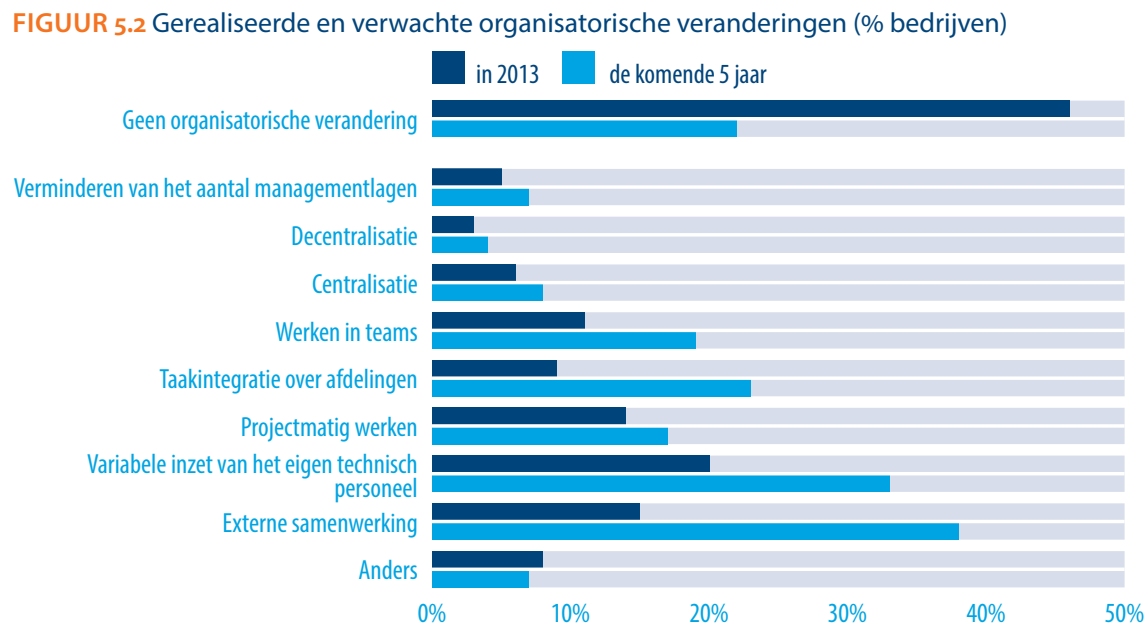

Bron: ROA, Arbeidsmarktmonitor Metalektro, 2013

In de Arbeidsmarktmonitor Metalektro 2012 werd al geschreven dat er tijdens de crisisjaren 2008 en 2009 beduidend meer organisatorische veranderingen werden doorgevoerd. Het betrof hier met name veranderingen op het gebied van organisatie en management. Het leek alsof de afname van de hoeveelheid werk het voor bedrijven mogelijk maakte om aanpassingen in de werking en structuur van het bedrijf door te voeren. Figuur 5.3 laat zien dat er inderdaad een duidelijk negatief verband is tussen de gerealiseerde organisatorische veranderingen en de omzet in de sector. In jaren waarin de omzet daalde, steeg het percentage bedrijven dat een organisatorische verandering heeft gerealiseerd. Andersom geldt ook dat in de periode 2009-2011, waarin de omzet steeg, het percentage bedrijven dat een organisatorische verandering heeft doorgevoerd daalde. 
FIGUUR 5.3 Gerealiseerde organisatorische veranderingen en de omzet in de Metalektro

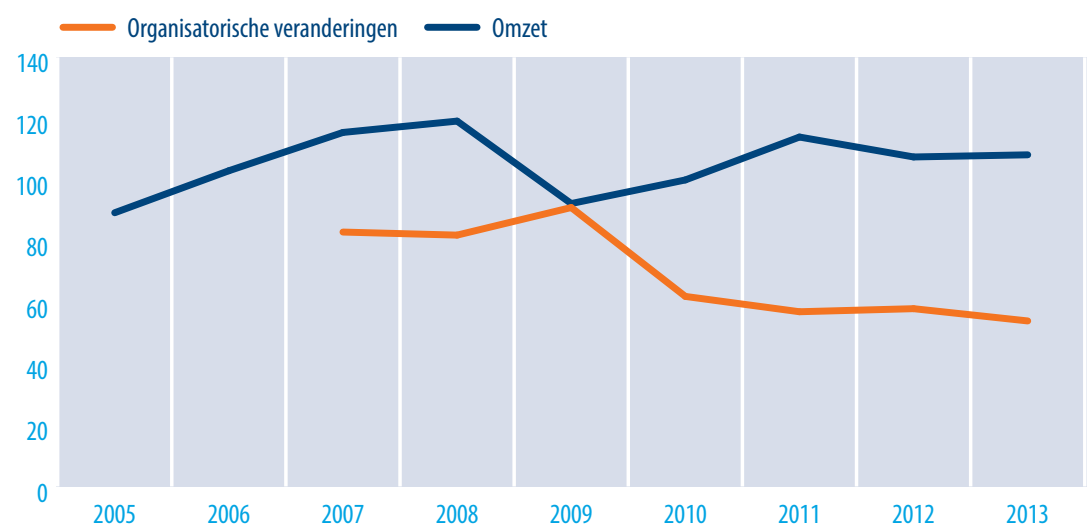

Bron: ROA, Arbeidsmarktmonitor Metalektro, 2007-2013; CBS, 2005-2013

TEKSTBOX 5.2 De economische crisis als katalysator voor organisatorische verandering

Dat de economische crisis mogelijkheden kan bieden voor herpositionering, blijkt ook uit een interview met Harrie van der Heijden van Mayfran International B.V.. Binnen Mayfran International heerste het gevoel dat nog meer uit het bedrijf te halen was dan tot dan toe werd gedaan. De crisis was het moment om daar gestalte aan te geven. Daarom werd de nieuwe organisatiestructuur geïntroduceerd (de business unit structuur opgeheven), werd er een managementlaag geschrapt en werd recentelijk gestart met de invoering van HPO (High Performance Organization). Met deze veranderingen is Mayfran nog beter klaar voor de toekomst.

In Figuur 5.4 is weergegeven hoeveel procent van de bedrijven aangegeven heeft dat de organisatorische verandering die zij doorgevoerd hebben volgens plan is verlopen. Uit de figuur blijkt dat de ene innovatie meer implementatieproblemen ondervindt dan de andere. De paar bedrijven die het aantal managementlagen verminderd hebben en/ of een decentralisatie hebben toegepast, geven aan dat de implementatie volgens plan is verlopen. Meer dan acht op de tien bedrijven geven aan dat het variabel inzetten van het eigen technisch personeel geheel volgens plan is verlopen. Dit is een duidelijke verbetering ten opzichte van vorig jaar, toen minder dan de helft van de bedrijven aangaf dat deze vorm van verandering volgens plan was verlopen. Bedrijven die een verandering in de externe samenwerking hebben doorgevoerd zijn over het algemeen erg tevreden: meer dan $90 \%$ geeft aan dat de implementatie volgens plan is gegaan. 
FIGUUR 5.4 Organisatorische veranderingen waarvan de implementatie geheel volgens plan is verlopen (van \% bedrijven die de betreffende verandering heeft doorgevoerd)

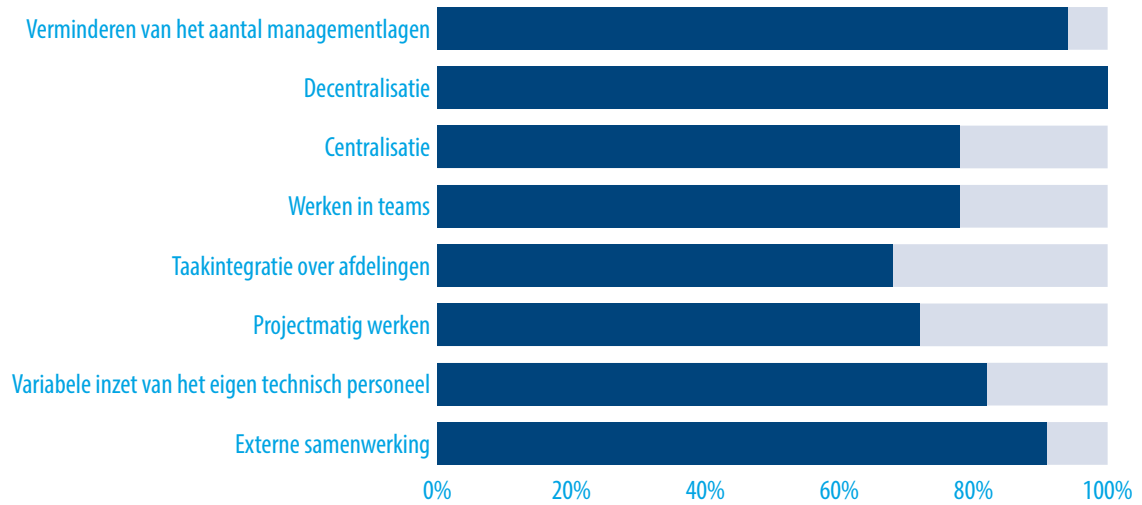

Bron: ROA, Arbeidsmarktmonitor Metalektro, 2013

In Figuur 5.5 gaan we in op de bedrijven die van plan zijn de komende vijf jaar een organisatorische verandering door te voeren. Deze bedrijven is gevraagd wat het hoofddoel van het doorvoeren van deze organisatorische verandering is. Uit de figuur blijkt dat twee doelen vaak genoemd worden (onafhankelijk van de geplande organisatorische verandering). Het betreft de kwaliteitsverbetering van de producten en de flexibilisering van de productie. Zo geven de meeste bedrijven (53\%) die van plan zijn een verandering door te voeren met betrekking tot teamwerk aan dat zij dit doen om de kwaliteit van de producten te verbeteren. Ook het verhogen van de productiviteit per werknemer (24\%) en de flexibilisering van de productie (18\%) worden vaak als doel van werken in teams genoemd. Bedrijven die van plan zijn taakintegratie over afdelingen toe te passen doen dit voornamelijk om de productie te flexibiliseren (41\%). Dit doel hebben ook bedrijven die hun eigen technisch personeel variabel willen gaan inzetten: $54 \%$ doet dit met het doel om de productie te flexibiliseren. Ook onder bedrijven die een externe samenwerking willen starten geeft een groot percentage (35\%) aan dat zij dit doen om de productie te flexibiliseren. Het aantrekkelijker worden als werkgever wordt niet vaak genoemd als hoofddoel voor de verwachte organisatorische veranderingen. 
FIGUUR 5.5 Hoofddoel van geplande organisatorische veranderingen in de komende vijf jaar (\% bedrijven die de desbetreffende verandering de komende vijf jaar willen doorvoeren)

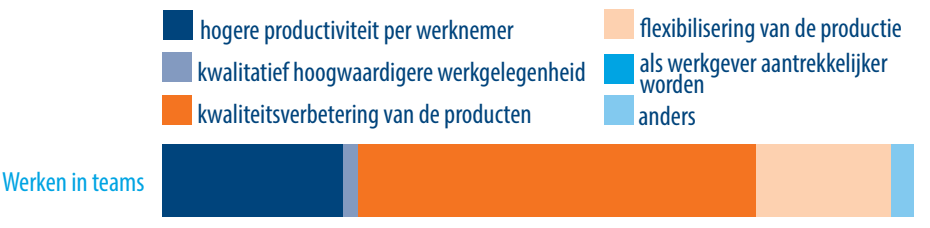

Taakintegratie over afdelingen

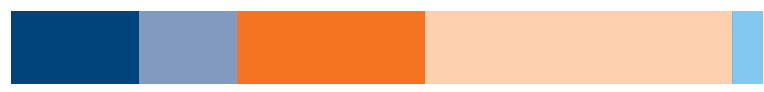

Variabele inzet van het eigen technisch personeel

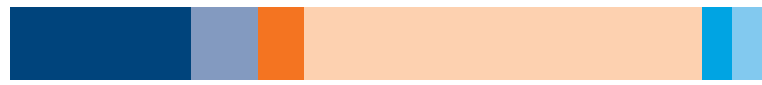

Externe samenwerking

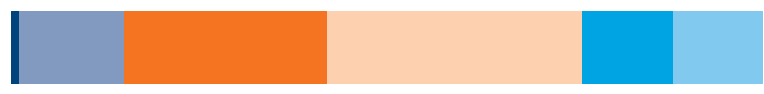

$0 \%$

$20 \%$

$40 \%$

$60 \%$

$80 \%$

Bron: ROA, Arbeidsmarktmonitor Metalektro, 2013

\subsection{Aan de grote behoefte aan breed inzetbare uitvoerende technici wordt vrijwel altijd voldaan}

Naast veranderingen gericht op de organisatie en het management van Metalektro bedrijven, wordt hier ingegaan op vernieuwingen van het menselijk kapitaal van bedrijven. Binnen de sector wordt brede inzetbaarheid gezien als een belangrijke manier om het menselijk kapitaal van het personeel goed te benutten. Hoewel tussen 2008 en 2011 het percentage bedrijven dat behoefte had aan breed inzetbare uitvoerende technici is gedaald van 91\% naar 51\%, heeft in 2012 en 2013 weer ongeveer drie kwart behoefte hieraan. Figuur 5.6 toont de behoefte aan breed inzetbaar personeel naar functiecategorie. Slechts $2 \%$ van de bedrijven geeft aan geen behoefte te hebben aan breed inzetbare uitvoerende technici. Er is binnen bedrijven ook een grote behoefte aan breed inzetbaar personeel in de ondersteunende technische functies. Ongeveer $50 \%$ van de bedrijven geeft aan in (zeer) sterke mate behoefte te hebben aan brede inzetbaarheid onder dit type medewerkers. Brede inzetbaarheid schijnt minder van belang onder technisch opgeleide verkopers, leidinggevende niet-technisch personeel en ondersteund niet-technisch personeel. Tenslotte valt uit Figuur 5.6 op te maken dat de technisch opgeleide verkopers de meest specialistische werknemers zijn. Meer dan één op de vier bedrijven heeft helemaal geen behoefte aan breed inzetbaar personeel in deze functiecategorie. 
FIGUUR 5.6 Behoefte aan breed inzetbaar personeel naar functiecategorie (\% bedrijven)

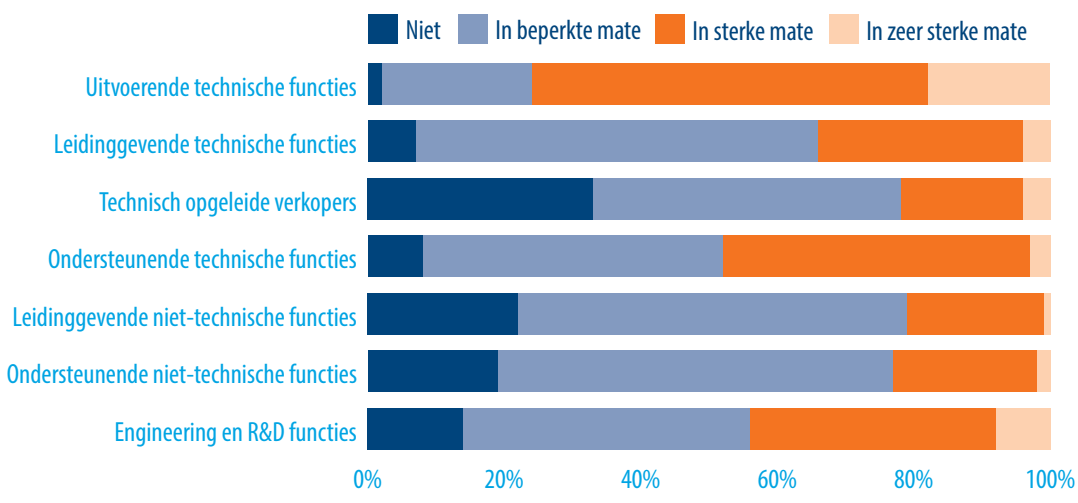

Bron: ROA, Arbeidsmarktmonitor Metalektro, 2013

Omdat de behoefte aan brede inzetbaarheid onder uitvoerende technici het grootst is, wordt in Figuur 5.7 ingegaan op de vraag of de behoefte aan dit type personeel afhankelijk is van de bedrijfsgrootte. Er wordt onderscheid gemaakt tussen 4 typen bedrijven: bedrijven met 0-50 medewerkers ( $N=40)$, bedrijven met 51-100 medewerkers $(N=50)$, bedrijven met 101-250 medewerkers $(\mathrm{N}=61)$ en bedrijven met meer dan 250 medewerkers $(\mathrm{N}=29)$. Het is opvallend dat de kleinste bedrijven aan de ene kant het vaakst aangeven geen behoefte te hebben aan breed inzetbare uitvoerende technici (6\%), en aan de andere kant ook het vaakst aangeven in zeer sterke mate behoefte te hebben aan breed inzetbare uitvoerende technici (30\%). Waarschijnlijk is de groep kleine bedrijven erg heterogeen zowel in het aantal medewerkers als ook in de mate van bedrijfsspecialisatie. Afhankelijk van de mate waarin deze kleine bedrijven zich specialiseren kan het daarom ofwel zo zijn dat de medewerkers een breed scala aan taken uitvoeren ofwel dat zij zich kunnen richten op één gespecialiseerde taak. Bedrijven met meer dan 50 medewerkers geven allemaal aan dat zij minimaal in beperkte mate behoefte hebben aan breed inzetbare uitvoerende technici. Voor de bedrijven met meer dan 100 medewerkers geldt dat $80 \%$ van de bedrijven aangeeft in (zeer) sterke mate behoefte te hebben aan breed inzetbare uitvoerende technici.

FIGUUR 5.7 Behoefte aan breed inzetbare uitvoerende technici naar bedrijfsgrootte (\% bedrijven)

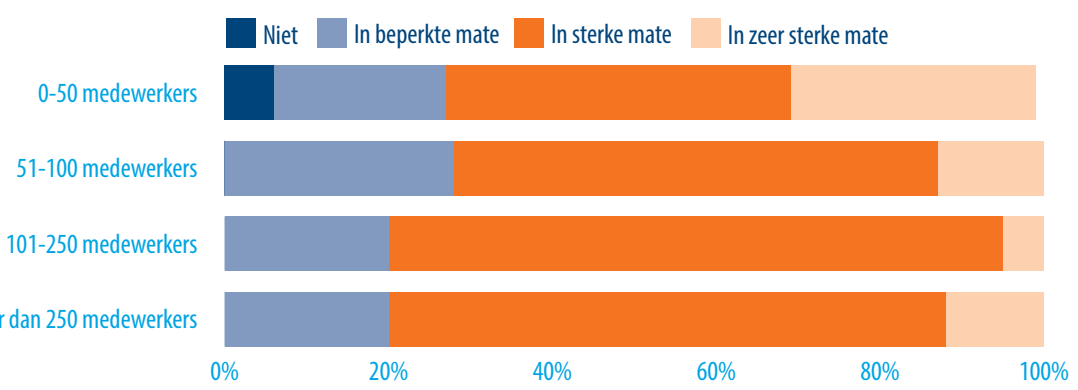

Bron: ROA, Arbeidsmarktmonitor Metalektro, 2013 
Figuur 5.8 gaat in op de vraag of binnen metalektrobedrijven ook daadwerkelijk aan de behoefte aan breed inzetbaar personeel wordt voldaan. Voor de verschillende functiecategorieën is het percentage bedrijven aangegeven waarbinnen het personeel (meer dan) voldoende breed inzetbaar is. Voor alle functiecategorieën geldt dat minimaal $60 \%$ van de bedrijven tevreden is met de brede inzetbaarheid van het personeel. Bij uitvoerende technici geldt dat maar liefst 93\% van de bedrijven vindt dat zij (meer dan) voldoende breed inzetbaar zijn. Ook het engineering en R\&D personeel is in een ruime meerderheid van de bedrijven (91\%) voldoende breed inzetbaar. Dit wil echter niet zeggen dat werknemers met beide functieprofielen even breed inzetbaar zijn want onder de engineers en de R\&D medewerkers is de behoefte aan brede inzetbaarheid stukken lager dan onder de uitvoerende technici (zie Figuur 5.7). Onder de leidinggevende (technisch en niet-technisch) is de discrepantie tussen de behoefte aan en de beschikbaarheid van breed inzetbaar personeel het grootst. $33 \%$ respectievelijk $25 \%$ van de bedrijven geeft aan dat de technisch respectievelijk niet-technisch leidinggevenden onvoldoende breed inzetbaar zijn.

FIGUUR 5.8 Verhouding tussen behoefte en beschikbaarheid breed inzetbaar personeel (\% bedrijven)

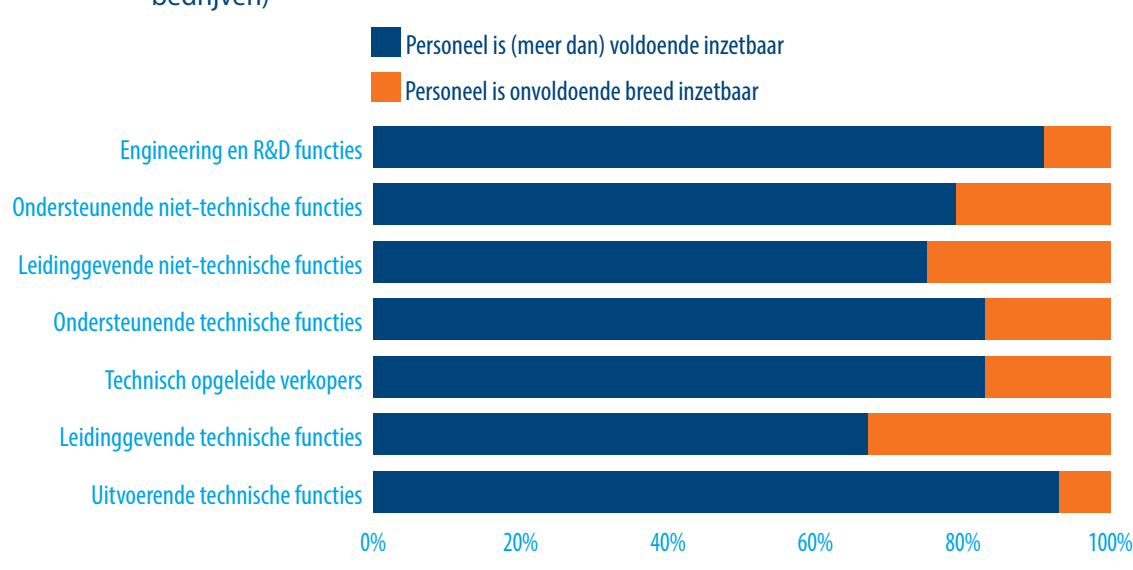

Bron: ROA, Arbeidsmarktmonitor Metalektro, 2013

Omdat de behoefte aan brede inzetbaarheid onder uitvoerende technici het grootst is, wordt in Figuur 5.9 ingegaan op de achterliggende redenen voor deze behoefte. Al sinds de eerste keer dat naar deze redenen is gevraagd binnen de Arbeidsmarktmonitor Metalektro (2005) staat de mogelijkheid om schommelingen in de bedrijfsdrukte op te vangen bovenaan in de lijst met redenen. Ook dit jaar geeft weer meer dan $70 \%$ van de bedrijven aan dat dit een belangrijke reden is voor de behoefte aan breed inzetbare uitvoerende technici. Daarnaast geldt voor bijna zes op de tien bedrijven dat vervanging tijdens afwezigheid een reden is voor hun behoefte aan breed inzetbare uitvoerende technici. Product- en/of procesvernieuwingen (45\%) en het aantrekkelijker maken van 
de functies (44\%) worden ook door bijna de helft van de bedrijven als reden genoemd. Alle andere antwoordcategorieën worden beduidend minder vaak genoemd.

FIGUUR 5.9 Redenen voor de behoefte aan breed inzetbare uitvoerende technici (\% bedrijven)

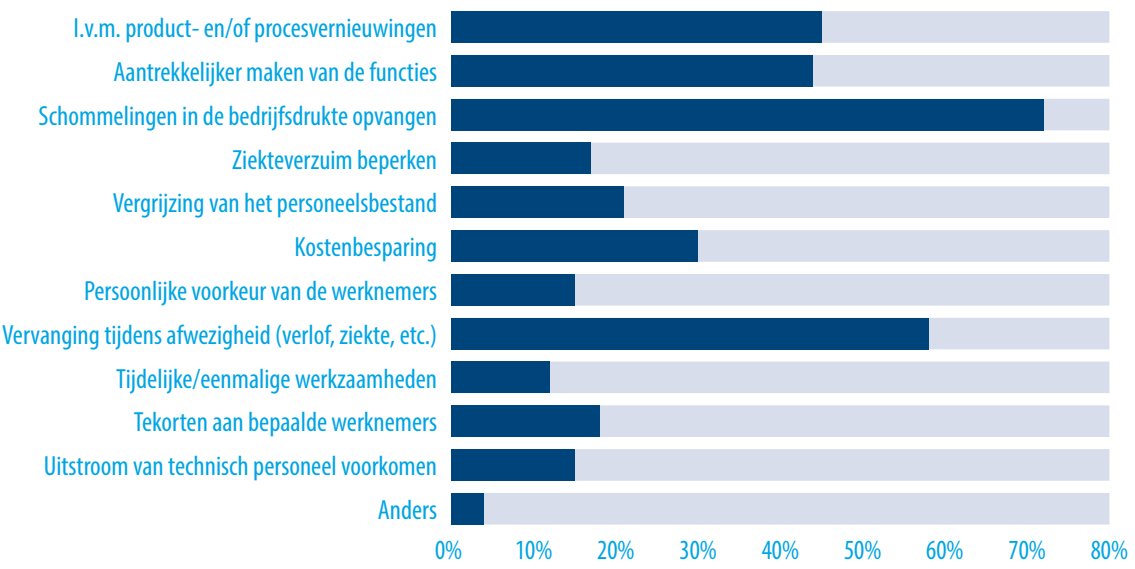

Bron: ROA, Arbeidsmarktmonitor Metalektro, 2013

TEKSTBOX 5.3 De voordelen van brede inzetbaarheid bij WP Haton

Aggie van Baal - HR manager bij WP Haton - geeft aan dat er bijWP Haton veel aandacht wordt besteed aan multi-inzetbaarheid. Dit is ooit uit noodzaak ontstaan doordat één van de tekenaar/constructeurs last van zijn ogen kreeg. Hij is toen ook gaan assembleren. Inmiddels is deze combinatie van verschillende werkzaamheden veel gangbaarder geworden. Tijdens de assemblage ziet een tekenaar dan ook wat er voor de constructietekeningen van belang is en wat eventuele verbeterpunten zijn. Deze multiinzetbaarheid bevordert ook dat werknemers onderling van gedachten wisselen over de verschillende stappen van ontwerp tot product en dat levert voordelen op voor het ontwerp- en productieproces. WP Haton neemt daarom de tijd om multi-inzetbaarheid te ontwikkelen. Bovendien is multi-inzetbaarheid bij werving en selectie al een aandachtspunt omdat het zo belangrijk is geworden binnen WP Haton.

Op basis van de CBS informatie met betrekking tot de omzet in de Metalektro kan bovendien gekeken worden naar de relatie tussen de behoefte aan breed inzetbare uitvoerende technici en een maatstaf voor de algemene bedrijfsdrukte. Uit Figuur 5.10 blijkt echter geen eenduidige relatie tussen de behoefte aan breed inzetbare uitvoerende technici en de omzet in de Metalektro. Eerst namen beide tussen 2009 en 2010 toe, maar sinds 2010 lijkt er een negatief verband te zijn. Als de omzet toeneemt, daalt de behoefte aan breed inzetbaar personeel en andersom. Breed inzetbaar personeel lijkt daarmee meer van belang bij het opvangen van schommelingen op de korte termijn 
dan bij het opvangen van langere drukke periodes. Voor dit laatste wordt toch vaker een beroep gedaan op flexwerkers. ${ }^{9}$

FIGUUR 5.10 Behoefte aan breed inzetbare uitvoerende technici en de omzet in de Metalektro

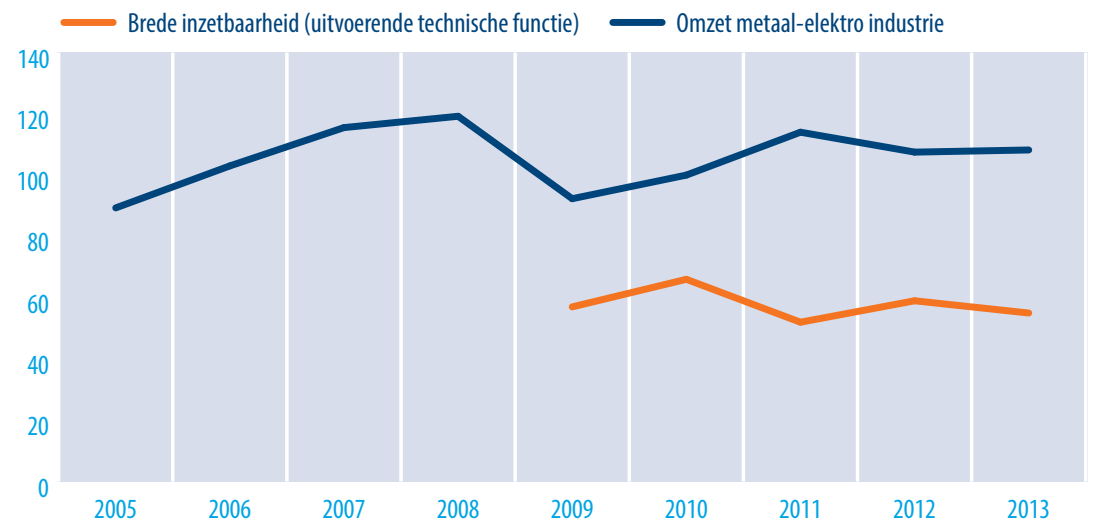

Bron: ROA, Arbeidsmarktmonitor Metalektro, 2007-2013; CBS, 2005-2013

\subsection{De komende vijf jaar meer samenwerking verwacht tussen metalektrobedrijven en hogescholen/universiteiten}

De tot dusver besproken vormen van organisatorische veranderingen hebben vrijwel uitsluitend betrekking op de 'binnenkant' van het bedrijf: de organisatie, het management en de medewerkers. Echter, bedrijven werken tegenwoordig op diverse manieren samen met externe partijen. Het kan dan gaan om allianties met andere bedrijven, maar ook om samenwerking met leveranciers, klanten en kennisorganisaties. In Figuur 5.11 is opgenomen hoeveel procent van de bedrijven nu bepaalde vormen van externe samenwerking heeft en wat de verwachtingen zijn voor de komende vijf jaar. De meest populaire vormen van externe samenwerking in 2013 waren samenwerking binnen een keten/met klanten (52\%), samenwerking binnen de sector (47\%) en lokale samenwerking (43\%). De samenwerking met kennisinstellingen (onderwijsinstellingen en kennisinstituten) ligt nu rond de 30\% maar bedrijven verwachten de komende jaren meer te gaan samenwerken met onderwijsinstellingen. Er wordt met name een grote toename verwacht in de samenwerking met hogescholen/universiteiten. De helft van de bedrijven verwacht de komende jaren hiermee te gaan samenwerken.

9 Zie Gerards, R. (2014), Tijdelijke contracten mogelijk voorbode langer herstel. Economisch Statistische Berichten. 99 (4681), 177. Hieruit blijkt op basis van cijfers van de Arbeidsmarktmonitor Metalektro 2010-2014 dat de omvang van de flexibele schil duidelijk gerelateerd is aan de omzet in de sector. 
FIGUUR 5.11 Vormen van externe samenwerking in 2013 (\% bedrijven)

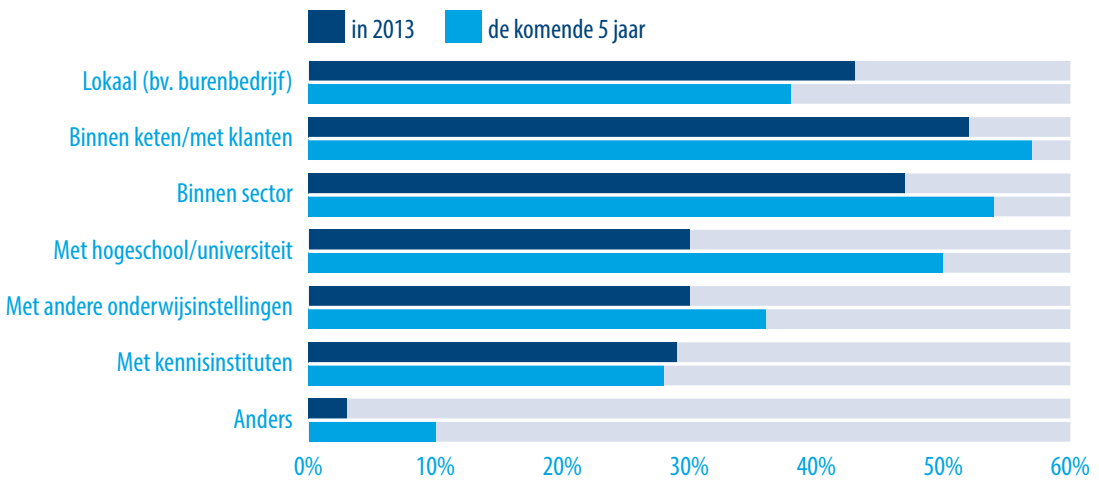

Bron: ROA, Arbeidsmarktmonitor Metalektro, 2013

TEKSTBOX 5.4 Regionale samenwerking tussen metalektrobedrijven in de Zaanstreek

12 jaar geleden is op initiatief van de lokale Kamer van Koophandel de Vereniging Metalektro Zaanstreek opgericht, aldus Hilda Kluessien, HR Manager bij Royal Duyvis Wiener en bestuurslid van de vereniging. Deze vereniging heeft 50 lidbedrijven en is daarmee een factor van belang in de regio, onder meer in overleg en samenwerking met bijvoorbeeld gemeenten of KVK. De vereniging vertegenwoordigt zowel grote als kleine bedrijven en is daarmee tamelijk uniek. Een van de originele doelstellingen was de bevordering van in- en uitbesteding tussen de lidbedrijven. Tegenwoordig is de vereniging vooral actief in het bevorderen van communicatie tussen de lidbedrijven, het bevordering van de instroom in het technische (beroeps)onderwijs en de kwaliteit daarvan. Eén van de vruchten die het werk van de vereniging heeft afgeworpen is de vestiging van de Techniekcampus, waarin meerdere opleidingen (bouw, elektrotechniek en meer) onder één dak zitten. De Techniekcampus verbetert de aansluiting tussen onderwijs en arbeidsmarkt. Zo was er op een gegeven moment een daling aan leerlingen mbo mechatronica terwijl er wel vraag naar was in de regio. Binnen de Techniekcampus is daar toen de focus op gelegd.

Een specifieke vorm van samenwerking met andere bedrijven is het uitbesteden van eigen activiteiten aan een ander bedrijf. Uitbesteding kan zowel binnen als buiten Nederland plaatsvinden. Uit Figuur 5.12 is op te maken hoeveel procent van de bedrijven in 2013 verschillende activiteiten uitbesteed heeft. Omdat bedrijven een bepaalde activiteit (zoals productie) zowel binnen als buiten Nederland kunnen uitbesteden, tellen de percentages in de figuur niet op tot 100. 
FIGUUR 5.12 Vormen van uitbesteding in 2013 (\% bedrijven)

Ja, binnen NL__ Ja, naar het buitenland _ Nee

Administratieve activiteiten

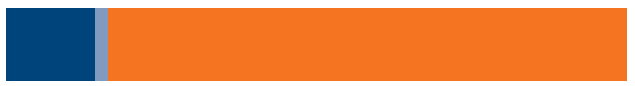

Ondersteunende activiteiten

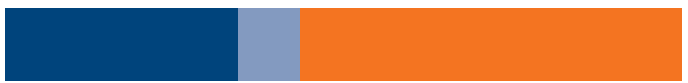

Onderzoeksactiviteiten (R\&D)

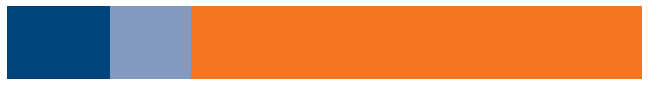

Productieactiviteiten

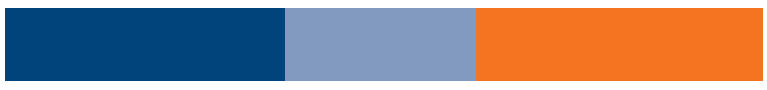

0

20

40

60

80

100

Bron: ROA, Arbeidsmarktmonitor Metalektro, 2013

Productieactiviteiten worden door metalektrobedrijven relatief het meest uitbesteed. $69 \%$ van de bedrijven besteedt momenteel productieactiviteiten uit. Ook ondersteunende activiteiten worden relatief vaak uitbesteed (43\%). Beide vormen van uitbesteding vinden met name binnen Nederland plaats ( $41 \%$ voor productieactiviteiten en $34 \%$ voor ondersteunende activiteiten). Administratieve activiteiten worden het minst vaak uitbesteed (15\%). Als er al uitbesteding van administratieve activiteiten plaatsvindt, dan is dit vrijwel altijd binnen Nederland georganiseerd (13\%). Onderzoeksactiviteiten worden door $27 \%$ van de bedrijven uitbesteed.

In Figuur 5.13 wordt ingegaan op de verwachte verandering in de uitbesteding van activiteiten in het binnen- en buitenland. Uit de figuur blijkt dat de mate waarin bedrijven hun activiteiten uitbesteden de komende jaren nauwelijks aan verandering onderhevig is. Voor alle activiteiten geldt dat minimaal drie kwart van de bedrijven van plan is de omvang van de uitbesteding binnen Nederland en buiten Nederland onveranderd te laten. De grootste toename wordt verwacht in de uitbesteding van productieactiviteiten binnen Nederland: $9 \%$ van de bedrijven verwacht hier een toename. Toch zijn er ook een aantal bedrijven die van plan zijn minder productieactiviteiten uit te besteden: $14 \%$ van de bedrijven verwacht een afname in de binnenlandse uitbesteding, 20\% verwacht een afname in de buitenlandse uitbesteding. 
FIGUUR 5.13 Verwachte verandering in uitbesteding van activiteiten in de komende vijf jaar (\% bedrijven)

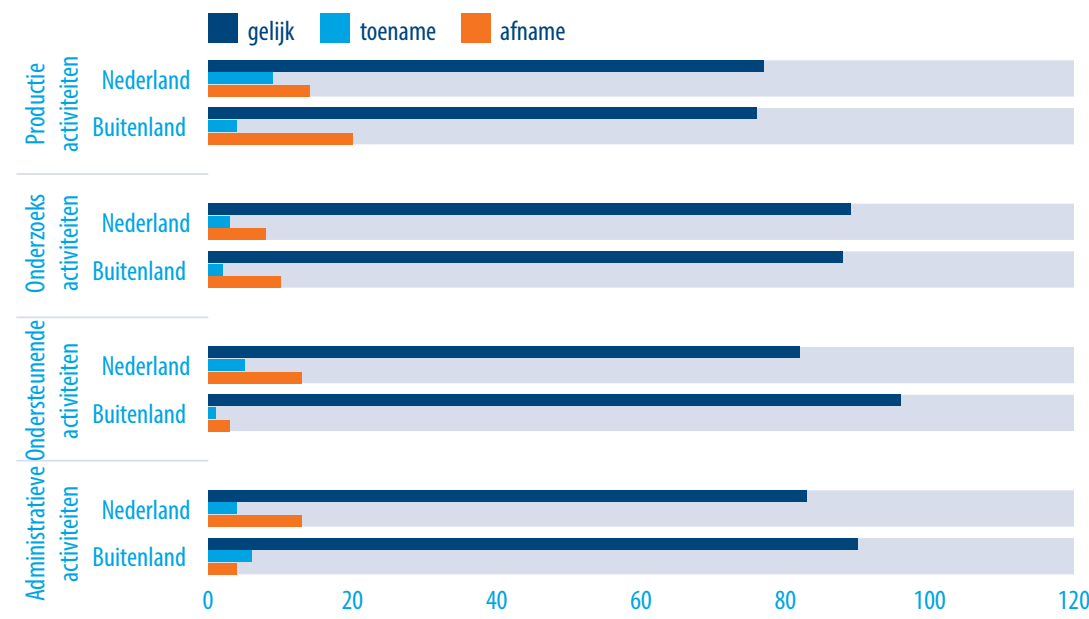

Bron: ROA, Arbeidsmarktmonitor Metalektro, 2013 


\section{6 \\ PENSIONERING: \\ VERWACHTINGEN EN UITDAGINGEN}

Het percentage oudere werknemers in de Metalektro is de afgelopen jaren gestaag toegenomen. Gezien de leeftijdsopbouw van het huidige personeelsbestand zal dit nog verder stijgen en zal de groep die de komende jaren met pensioen gaat groter worden. Bedrijven verwachten in vergelijking tot voorgaande jaren echter een afname van de pensioenuitstroom. Het is niet ondenkbaar dat bedrijven het aantal werknemers dat de komende jaren met pensioen zal gaan - en de daarmee gepaard gaande vervangingsproblemen -onderschatten. Om de verwachte vervangingsproblemen door pensionering te ondervangen nemen bedrijven echter wel een reeks maatregelen. De meest populaire maatregel is het aantrekken van nieuwe werknemers, zowel goed opgeleide krachten als werknemers die vervolgens intern worden opgeleid. Ook brede inzetbaarheid van de huidige werknemers moet voor een groot deel van de bedrijven de problemen als gevolg van pensioneringen inperken. Daarnaast werd het intensiveren van de relaties met het onderwijsveld in de afgelopen jaren door een toenemend aantal bedrijven gezien als een manier waarop vervangingsproblemen kunnen worden verminderd.

Om oudere werknemers voldoende inzetbaar te houden gebruikten Metalektrobedrijven in 2013 verschillende HR-instrumenten. Bijna alle bedrijven bieden hun medewerkers opleidingsmogelijkheden. Daarnaast worden oudere werknemers ontlast; bijvoorbeeld door hen werkzaamheden te laten verrichten waarbij de kennisoverdracht aan jongere werknemers centraal staat. Verschillende instrumenten, zoals het aanpassen van het werk aan de belastbaarheid van individuele medewerkers, worden door een deel van de bedrijven vaker ingezet voor oudere medewerkers. 


\subsection{Vergrijzing in de Metalektro nog altijd hoger dan gemiddelde van alle sectoren in Nederland}

De werkende beroepsbevolking vergrijst. Dit is geen nieuwe ontwikkeling; de netto participatie van ouderen stijgt al sinds begin jaren '9o en zet tot op heden door. Hiermee is de gemiddelde leeftijd van de werkzame beroepsbevolking gestegen over de gehele breedte van de arbeidsmarkt. Ook binnen de Metalektro is sprake van een groeiend aandeel werkende ouderen, waartoe we in deze rapportage medewerkers in de leeftijd van 50 tot en met 64 rekenen. In Figuur 6.1 is de veroudering van werknemers binnen de Metalektro duidelijk waar te nemen voor de periode 2006-2012. Tussen 2006 en 2010 lag het percentage werkzame ouderen binnen de Metalektro elk jaar tot een procentpunt lager dan in alle sectoren samen. Dit veranderde sinds 2011, toen het percentage ouderen in de Metalektro voor het eerst hoger lag dan voor alle sectoren.

FIGUUR 6.1 Percentage werkenden in de leeftijd 50-64 in de Metalektro en van alle sectoren in Nederland, (2006-2012)

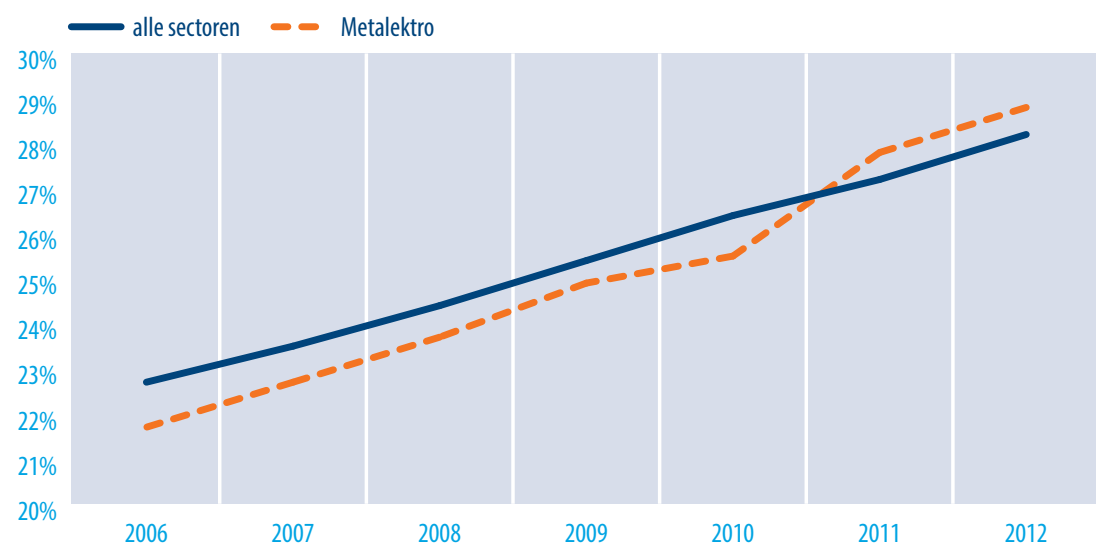

Bron: CBS, Enquête beroepsbevolking, 2006-2012

Op basis van de ontwikkeling die wordt geschetst in Figuur 6.1 kan worden verwacht dat bedrijven in de Metalektro de komende jaren meer te maken krijgen met uitstroom vanwege pensionering. Hoewel de stijging van het aandeel ouderen in de Metalektro tussen 2011 en 2012 kleiner is dan in het voorafgaande jaar, blijft de stijging voortduren en houdt deze gelijke tred met de stijging van het aandeel werkenden in alle sectoren. De gegevens van 2013 zijn nog niet per sector beschikbaar. Via het pensioenfonds van de Metalektro (PME) is deze informatie echter wel verkregen. Aan de hand van deze informatie is in Figuur 6.2 de leeftijdsopbouw van de Metalektro voor 2013 in kaart gebracht. Volgens deze gegevens is $31 \%$ van de medewerkers in de Metalektro 50 jaar of ouder. 


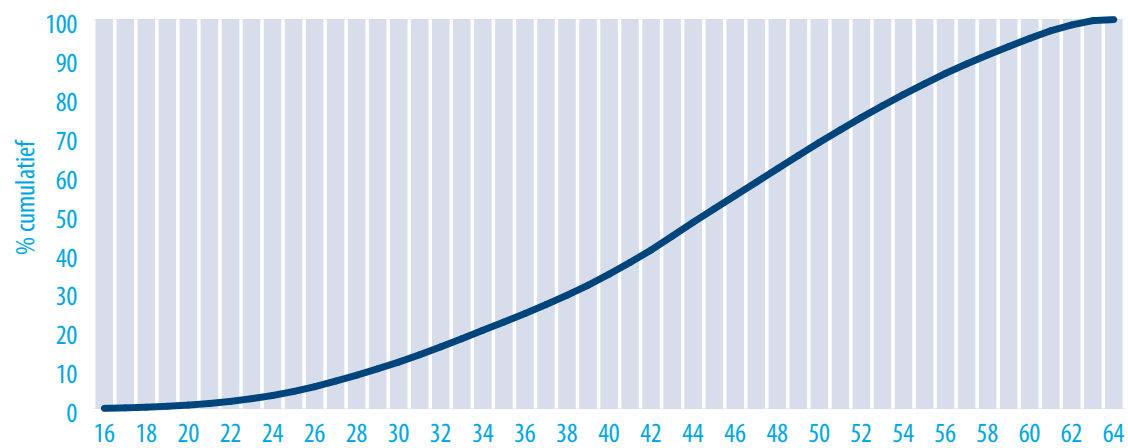

Bron: PME, 2013

De leeftijdsverdeling voor de Metalektro als geheel kan er voor individuele bedrijven natuurlijk anders uit zien. Er bestaan bijvoorbeeld verschillen in het aandeel 50- tot 64-jarigen tussen de deelsectoren van de Metalektro (zie Figuur 6.3). Dit verschil tussen deelsectoren is echter aanzienlijk kleiner geworden in de periode 2010-2012. In de basismetaal is het percentage ouderen in alle gepresenteerde jaren het hoogst. Het aandeel ouderen in deze sector steeg bovendien aanzienlijk in de jaren 2007-2009. Ook in de transportmiddelen sector groeide het percentage werknemers in de leeftijd 50-64 tot 2009. Voor beide deelsectoren geldt dat er sinds 2009 een daling in het aandeel ouderen is ingetreden. Voor de overige deelsectoren steeg het percentage ouderen juist fors tussen 2009 en 2010 en zette deze stijging zich gestaag voort tot 2011. Het jaar daarna bleef in zekere mate stabiel met een gemiddeld percentage ouderen van afgerond 29 procent.

FIGUUR 6.3 Percentage werkenden in de leeftijd 50-64 in de metalektrosectoren, 2006-2012

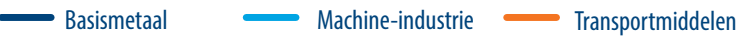

Metaalproducten - Elektrotechniek

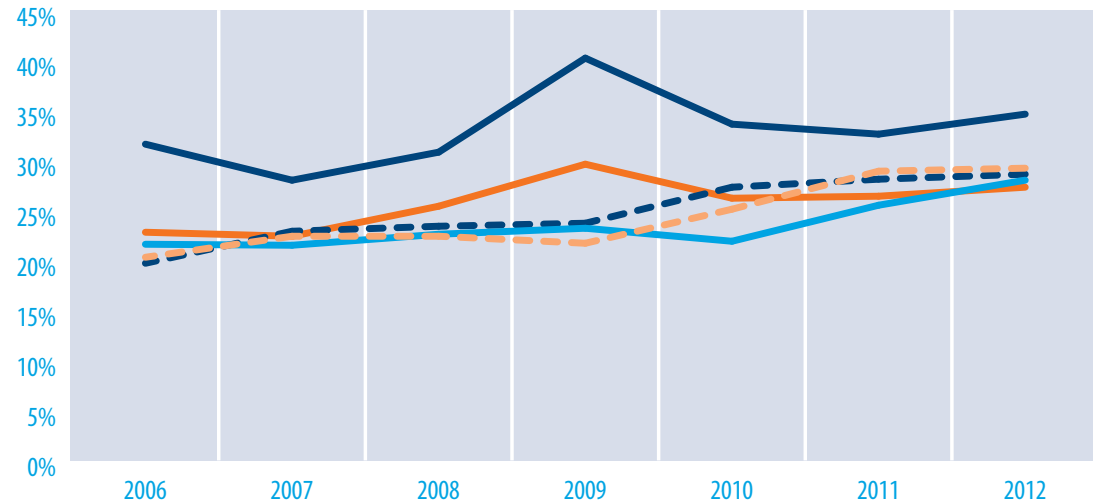

Bron: CBS, Enquête beroepsbevolking, 2006-2012 
Op basis van deze leeftijdsontwikkelingen is het waarschijnlijk dat werkgevers in toenemende mate verwachten dat ze met pensioneringen te maken gaan krijgen. Uit Figuur 6.4 blijkt echter dat het geschatte aandeel van het personeel dat binnen vijf jaar met pensioen gaat, sinds de intrede van de crisis in 2008 dalende is. Voor de uitvoerende technische functies duurde deze trend voort tot 2013. De verwachte uitstroom van gepensioneerden is zoals in voorgaande jaren het hoogst voor uitvoerende technici, maar daalt verder van 3,6\% in 2012 naar 3,0\% in 2013. De schatting van de uitstroom uit deze functiecategorie door het SEO (op basis van CBS-gegevens) ligt aanzienlijk hoger met 4 tot 6 procent. Hieraan ligt de veronderstelling ten grondslag dat het grootste deel van de 60-plussers die momenteel werkzaam zijn in de Metalektro, binnen vijf jaar met pensioen gaat. Het is echter ook denkbaar dat een deel hiervan na 65 doorwerkt. De prognoses van het ROA geven een geschatte vervangingsvraag van jaarlijks gemiddeld 3,6\% voor de technische en industrieberoepen tot 2018. ${ }^{10}$ Deze vervangingsvraag ontstaat niet uitsluitend, maar vaak wel grotendeels door pensionering. De schattingen van CBS en ROA wijzen dus op een aandeel vertrekkende oudere werknemers dat hoger ligt dan de inschatting die bedrijven in de sector maken.

Voor leidinggevende technici is de verwachte uitstroom naar pensionering het hardst gedaald ten opzichte van 2012 (met ruim 1,5 procentpunt). De verwachte uitstroom van ondersteunende technici daalde licht. Voor technisch opgeleide verkopers blijft het verwachte pensioenpercentage met afgerond $2 \%$ grofweg gelijk aan het voorgaande jaar. Het percentage medewerkers in engineering en $R \& D$ functies dat naar verwachting binnen vijf jaar met pensioen gaat is licht toegenomen van 0,5\% in 2012 naar 0,8\% in 2013. ${ }^{11}$

Hiermee is de huidige verwachte uitstroom van ouderen in de komende jaren voor de meeste technische functiecategorieën, waaronder de grootste groep van uitvoerende technici, weer gedaald ten opzichte van het voorgaande jaar. Een verklaring hiervoor ligt mogelijk in de verhoging van de pensioenleeftijd die zich de afgelopen jaren heeft voltrokken, waardoor oudere medewerkers langer op de arbeidsmarkt blijven. Bovendien moeten werknemers in de Metalektro rekenkundig gezien - vanwege de dalende pensioenpremie - langer doorwerken om voor hetzelfde pensioen in aanmerking te komen. Beide ontwikkelingen kunnen ertoe bijdragen dat de (lang) verwachte uitstroom meer wordt uitgespreid of nog een aantal jaren wordt uitgesteld. Daarnaast bestaat de mogelijkheid dat (een deel van de) metalektrobedrijven de uitstroom naar pensionering onderschatten.

10 Dit betekent dat ten opzichte van het werkgelegenheidsniveau in 2012 gemiddeld jaarlijks 3,6 \% van de werkenden uitstroomt en vervangen moet worden.

11 Voor deze functiecategorie is de vraag naar de verwachte uitstroom naar pensionering in 2012 voor het eerst opgenomen in de vragenlijst. 
FIGUUR 6.4 Verwacht percentage medewerkers dat de komende vijf jaar met pensioen gaat per technische functiecategorie, 2006-2013
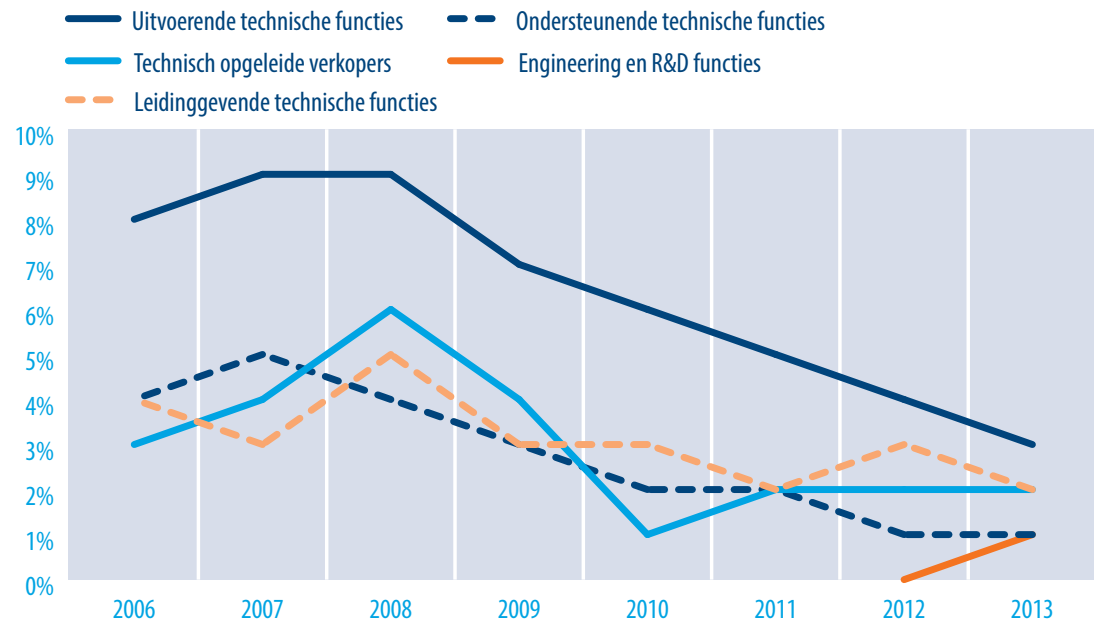

Bron: ROA, Arbeidsmarktmonitor Metalektro, 2006-2013

\subsection{Minder vervangingsproblemen verwacht}

Uit de vorige paragraaf bleek het verwachte percentage werknemers dat in de komende vijf jaar met pensioen gaat te zijn afgenomen. Toch zullen er altijd werknemers met pensioen gaan en ook vervangen moeten worden. Dit levert mogelijk problemen op doordat onze samenleving naast vergrijzing ook ontgroening kent en er dus relatief weinig mensen vanuit het onderwijs naar de arbeidsmarkt doorstromen. Dit wordt nog eens versterkt door een tekortschietende belangstelling voor het technisch onderwijs. ${ }^{12}$ Aan elk bedrijf is daarom gevraagd in hoeverre zij de komende vijf jaar vervangingsproblemen door pensionering verwachten. Figuur 6.5 geeft per functiecategorie het percentage bedrijven dat veel vervangingsproblemen verwacht. In 2012 was het percentage bedrijven dat veel vervangingsproblemen verwachtte voor de opvolgende vijf jaren grofweg gelijk aan 2011. In 2013 daalde dit percentage ten opzichte van de voorgaande twee jaren. Dit is opmerkelijk omdat CBS cijfers in Figuur 6.1 laten zien dat het percentage ouderen in de Metalektro sinds 2011 boven het landelijk gemiddelde ligt.

12 Uit de ROA arbeidsmarktprognoses voor de periode tot 2018 blijkt dat de verwachte instroom vanuit voor de Metalektro relevante opleidingen relatief laag blijft vergeleken bij de vraag (zie Hoofdstuk 7). 
FIGUUR 6.5 Percentage bedrijven dat in komende 5 jaar veel vervangingsproblemen verwacht door pensionering per technische functiecategorie, 2008-2013

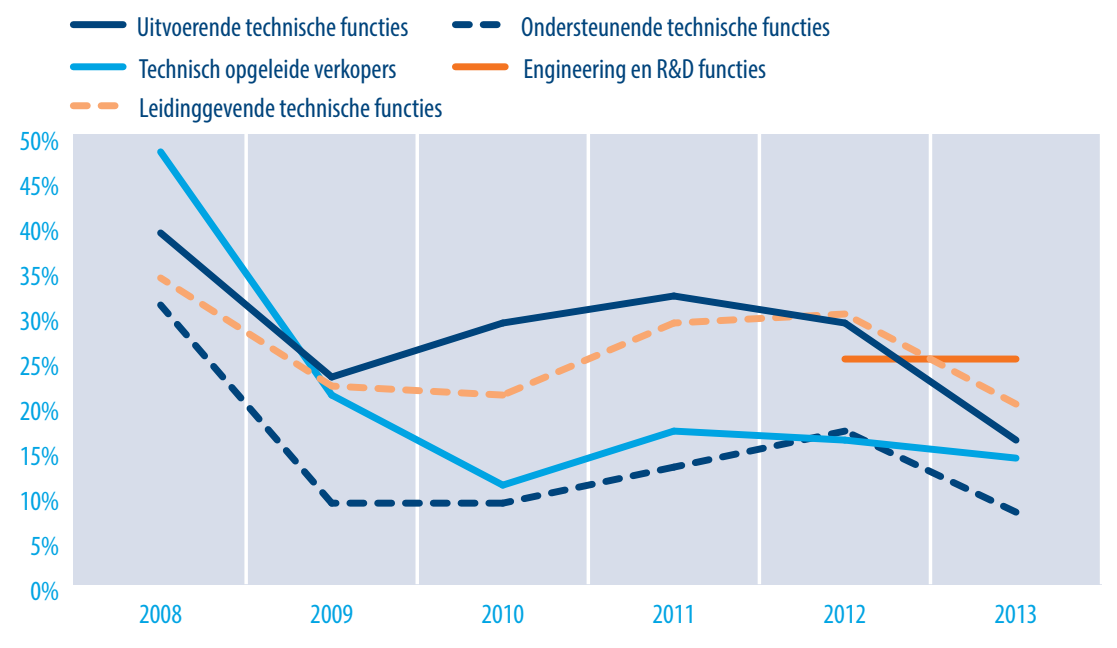

Bron: ROA, Arbeidsmarktmonitor Metalektro, 2008-2013

Ongeveer 14 procent van de bedrijven verwacht veel problemen bij het vervangen van technisch opgeleide verkopers. Dit is een lichte afname ten opzichte van de twee voorgaande jaren. Engineering en R\&D functies worden pas sinds 2012 onderscheiden en tonen op dit vlak geen verandering in 2013. Voor de overige drie functiecategorieën is een sterke daling te zien in het percentage bedrijven dat verwacht veel vervangingsproblemen te ondervinden in de komende jaren. De verwachte problemen zijn het kleinst en daalden het hardst ten opzichte van 2012 voor de ondersteunende technische functies. Slechts 8 procent van de bedrijven verwacht voor deze functiecategorie grote vervangingsproblemen. Dit strookt met een afname in de verwachte uitstroom naar pensionering vanuit deze functiecategorie zoals getoond in Figuur 6.4.

\subsection{Duurzame inzetbaarheid}

Bedrijven zullen ernaar streven de oudere werknemers die nog niet met pensioen gaan blijvend inzetbaar te houden. Hiertoe kan een breed scala aan HRM-instrumenten worden ingezet. Figuur 6.6 toont het gebruik van een aantal active-ageing instrumenten, dat wil zeggen acties die bedrijven inzetten op het gebied van duurzame inzetbaarheid van het personeel. Het meest toegepast om medewerkers duurzaam aan het werk te houden is het werken aan brede inzetbaarheid. 65 procent van de bedrijven geeft aan dit te doen. Ruim 6 van de 10 bedrijven heeft aandacht voor de (fysieke) belasting van haar medewerkers om zodoende voortdurende inzetbaarheid te stimuleren. Ook bij de werving van nieuw personeel wordt duurzame inzetbaarheid in beschouwing genomen. De helft van de bedrijven geeft aan rekening te houden met de leeftijdsop- 
bouw binnen het bedrijf bij het aannemen van nieuwe medewerkers. Voorts zijn er nog acties zoals het bewaken van de balans tussen werk en privé, het deeltijdpensioen en voorlichting over een gezonde leefstijl, welke door ongeveer een kwart tot een derde van de bedrijven worden ingezet om duurzame inzetbaarheid te bevorderen. Het regelmatig toetsen van de werkdruk vindt bij een veel kleiner aandeel van de bedrijven plaats (16\%). Buiten de instrumenten die zijn gepresenteerd in de figuur, blijken bedrijven creatief in het bedenken van meer informele manieren om duurzame inzetbaarheid te bevorderen (zie Tekstboxen 6.1 en 6.2).

FIGUUR 6.6 Gebruik van active-ageing instrumenten, (\% bedrijven), 2013

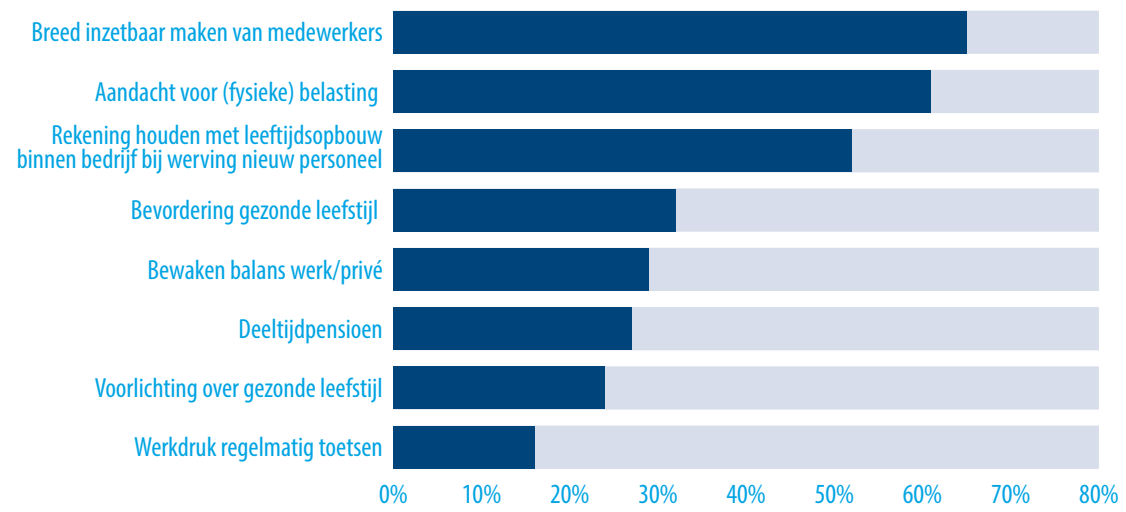

Bron: ROA, Arbeidsmarktmonitor Metalektro, 2013

TEKSTBOX 6.1 Collegialiteit als middel voor duurzame inzetbaarheid

Harrie van der Heijden - Manager Resources bij Mayfran International B.V. stelt dat concrete problemen rondom (duurzame) inzetbaarheid zoveel mogelijk worden voorkomen dan wel opgelost door het toepassen van het simpele principe van collegialiteit. Aangezien veel werknemers al lange tijd samenwerken, accepteren en compenseren de jongere werknemers dat de oudere medewerkers bij bepaalde werkzaamheden (deels) moeten worden ontzien. Hierbij wordt ingezet op een positieve waardering voor bewezen inzet van de oudere medewerkers en het besef dat de jongere werknemers van nu de ouderen van de toekomst zijn. Bovendien zorgt deze bredere samenwerking tussen jongere en oudere werknemers voor informele overdacht van kennis en vaardigheden. Binnen Mayfran bestaat daarnaast de mogelijkheid voor oudere werknemers om een cursus praktijkbegeleider te volgen om zich naderhand meer toe te leggen op kennisoverdracht en/of de coaching van jongere medewerkers.

In het streven naar een duurzame en optimale inzetbaarheid van alle medewerkers kan rekening gehouden worden met de leeftijd van medewerkers en daarbij behorende specifieke kenmerken en behoeften. Dit wordt ook wel leeftijdsbewust personeelsbeleid genoemd. ${ }^{13}$ Volgens Vanmullem en Hondeghem (2005) dient een leeftijdsbewust perso-

13 College voor arbeidszaken (2000) Leeftijdsbewust personeelsbeleid en ouderenbeleid. Den Haag: VNG Uitgeverij. 
neelsbeleid niet alleen rekening te houden met de oudere medewerkers, maar met alle medewerkers, dus met alle leeftijdscategorieën. ${ }^{14}$ Andere onderzoekers geven aan dat een leeftijdsbewust personeelsbeleid in het geheel achterhaald is en plaats moet maken voor een levensfase- of levensloopbewust personeelsbeleid..$^{15}$ Zo riep Van der Heijden organisaties op om hun HR-beleid niet af te stemmen op kalenderleeftijd, maar op individuele mogelijkheden, behoeftes, affiniteiten en wensen van hun medewerkers. ${ }^{16} \mathrm{Om}$ na te gaan in hoeverre metalektrobedrijven bij de inzet van HR instrumenten rekening houden met de leeftijd van hun medewerkers, is gevraagd om voor verschillende HR maatregelen aan te geven of ze deze in zijn algemeenheid toepassen en of deze vaker of juist minder vaak worden gebruikt voor personeel dat ouder is dan 45 jaar. Tabel 6.1 geeft het overzicht. We bespreken een aantal resultaten die eruit springen. Voor een drietal instrumenten blijkt dat bij het personeelsbeleid rekening gehouden wordt met oudere medewerkers. Zo heeft het aanpassen van werkzaamheden aan de belastbaarheid van individuele medewerkers bij $36 \%$ van de bedrijven relatief vaker betrekking op oudere werknemers. Daarnaast is bij een kwart van de bedrijven nadrukkelijk vaker sprake van werkzaamheden waarbij de overdracht van kennis centraal staat voor werknemers ouder dan 45. Ook de vermindering van het aantal werkuren is een instrument dat door een deel van de bedrijven (14\%) vaker voor het oudere personeel wordt ingezet.

TABEL 6.1 Meest ingezette HR-instrumenten in 2013, algemeen en voor 45+ werknemers (\% bedrijven)

\begin{tabular}{|l|c|c|}
\hline Ontwikkelingsinstrumenten en aanpassingen van het werk & $\begin{array}{c}\text { \% bedrijven dat } \\
\text { instrument inzet }\end{array}$ & $\begin{array}{c}\text { \% bedrijven dat } \\
\text { relatief vaker voor } \\
45+\text { inzet }\end{array}$ \\
\hline Opleidingsmogelijkheden & 97 & 0 \\
\hline Verbeteren/Arbo-aanpassen arbeidsomstandigheden/ergonomie/werkplek & 94 & 3 \\
\hline Medewerkers betrokken maken bij de ontwikkeling van het bedrijf & 92 & 0 \\
\hline Aanpassen werk/taken aan belastbaarheid individuele medewerkers & 90 & 36 \\
\hline Medewerkers wijzen op eigen verantwoordelijkheid m.b.t. employability & 87 & 1 \\
\hline Loopbaangesprekken & 81 & 0 \\
\hline Taak- of functieroulatie & 78 & 4 \\
\hline Werkzaamheden verrichten waarbij de overdracht van kennis centraal staat & 74 & 25 \\
\hline Aantal werkuren verminderen & 62 & 14 \\
\hline Preventief Medisch Onderzoek (PM0) of Vitaliteitscheck & 62 & 5 \\
\hline Werken op andere tijden & 59 & 6 \\
\hline EVC & 40 & 3 \\
\hline
\end{tabular}

Bron: ROA, Arbeidsmarktmonitor Metalektro, 2013

14 Vanmullem, K. \& Hondeghem, A. (2005) Een leeftijdsbewust personeelsbeleid bij de Vlaamse overheid: verkenning van het onderzoek. Leuven: SBOV.

15 Nauta, A., De Lange, A., \& Görtz, S. (2010). Lang zullen ze leven, werken en leren. Een schema voor het begrijpen en beïnvloeden van inzetbaarheid gedurende de levensloop. Gedrag \& Organisatie, 23(2), 136-157.

16 Van der Heijden, B. I., de Lange, A. H., Demerouti, E., \& Van der Heijde, C. M. (2009). Age effects on the employability-career success relationship. Journal of Vocational Behavior, 74(2), 156-164. 
TEKSTBOX 6.2 Leeftijdsafhankelijk HR-beleid is achterhaald, goed HR beleid is leeftijdsonafhankelijk

'Een goed HR-beleid is leeftijdsonafhankelijk', aldus Frans Kalkhoven, HR-manager bij Toyota Material Handling. Het HR-beleid van Toyota Material Handling richt zich niet specifiek op de duurzame inzetbaarheid van ouderen. Werknemers worden vanaf het begin aangemoedigd bezig te zijn met hun houding en beweging, om zoveel mogelijk te voorkomen dat curatieve maatregelen nodig zijn. Het is belangrijk dat werknemers zich richten op wat zij wél kunnen, in plaats van wat zij niet kunnen. Goede communicatie tussen leidinggevende en werknemers is hierbij essentieel, om zodoende een 'overlegstructuur' te creëren en te denken in mogelijkheden in plaats van beperkingen.

Dr. Simon Beausaert, universitair docent bij de vakgroep Educational Research and Development van de Universiteit Maastricht, doet onderzoek naar flexibiliteit en inzetbaarheid ('employability') van werknemers. Hij stelt dat leeftijdsbewust loopbaanbeleid achterhaald is. 'Uit wetenschappelijk onderzoek is gebleken dat het niet om leeftijd gaat, maar om je motivatie en hoe je naar de toekomst kijkt. De mate waarin een medewerker informeel leert, dagelijks kennis deelt en opzoekt, is een belangrijke voorspeller van flexibiliteit en inzetbaarheid. Vandaar dat we organisaties handvatten willen bieden om de uitwisseling van feedback en kennis op de werkvloer te vergroten. Bedrijven leggen vaak het accent op alleen formeel leren: cursussen en trainingen. Echter, informeel leren is goedkoper én je kunt er veel meer van leren', aldus Beausaert.

\subsection{Aanpak vervangingsproblemen}

Het aantrekken en zelf opleiden van nieuwe werknemers is een populaire maatregel om de verwachte vervangingsproblematiek te beperken. Het overgrote deel van de bedrijven past dit toe. Figuur 6.7 laat daarnaast zien dat het aandeel bedrijven dat deze maatregel inzet ten opzichte van 2012 met 10 procentpunt is toegenomen tot $82 \%$ en weer bijna op het niveau van 2011 is. Ook worden in meer dan de helft van de gevallen nieuwe, goed opgeleide werknemers aangenomen om verwachte vervangingsproblemen te voorkomen, al werd dit in 2013 iets minder toegepast dan in eerdere jaren. Het aannemen van schoolverlaters wordt ook nog altijd door de helft van de bedrijven genoemd in dit verband. Het streven naar brede inzetbaarheid van werknemers is eveneens een veel genoemde strategie. Bijna 6 op de 10 bedrijven maken gebruik van taakroulatie met als doel hun werknemers breed inzetbaar te maken en daarmee eventuele problemen door uitstroom van gepensioneerden op te vangen. Ook scholing kan hier een belangrijke rol spelen. Het aandeel bedrijven dat het huidige personeel om- of bijschoolt als maatregel tegen vervangingsproblematiek bedraagt iets meer dan een derde (36\%) van alle metalektrobedrijven en kende een daling in de afgelopen jaren. Een maatregel die duidelijk populairder is geworden in de afgelopen jaren is het intensiveren van relaties met het onderwijsveld. Dit is in lijn met de afspraken die zijn gemaakt in het Techniekpact, waarin staat dat samenwerking tussen onderwijs, bedrijfsleven en werknemers moet leiden tot een verbetering van de aansluiting van het onderwijs op de arbeidsmarkt en waarmee bovendien het aantal technici moet worden vergroot 
(Nationaal Techniekpact 2020). ${ }^{17}$ Ruim de helft van de metalektrobedrijven maakte in 2013 gebruik van samenwerking met dergelijke partners teneinde de vervangingsvraag die ontstaat door pensioneringen te ondervangen.

FIGUUR 6.7 HR-maatregelen om problemen met de vervanging van gepensioneerde technici te beperken (\% bedrijven), 2010-2013

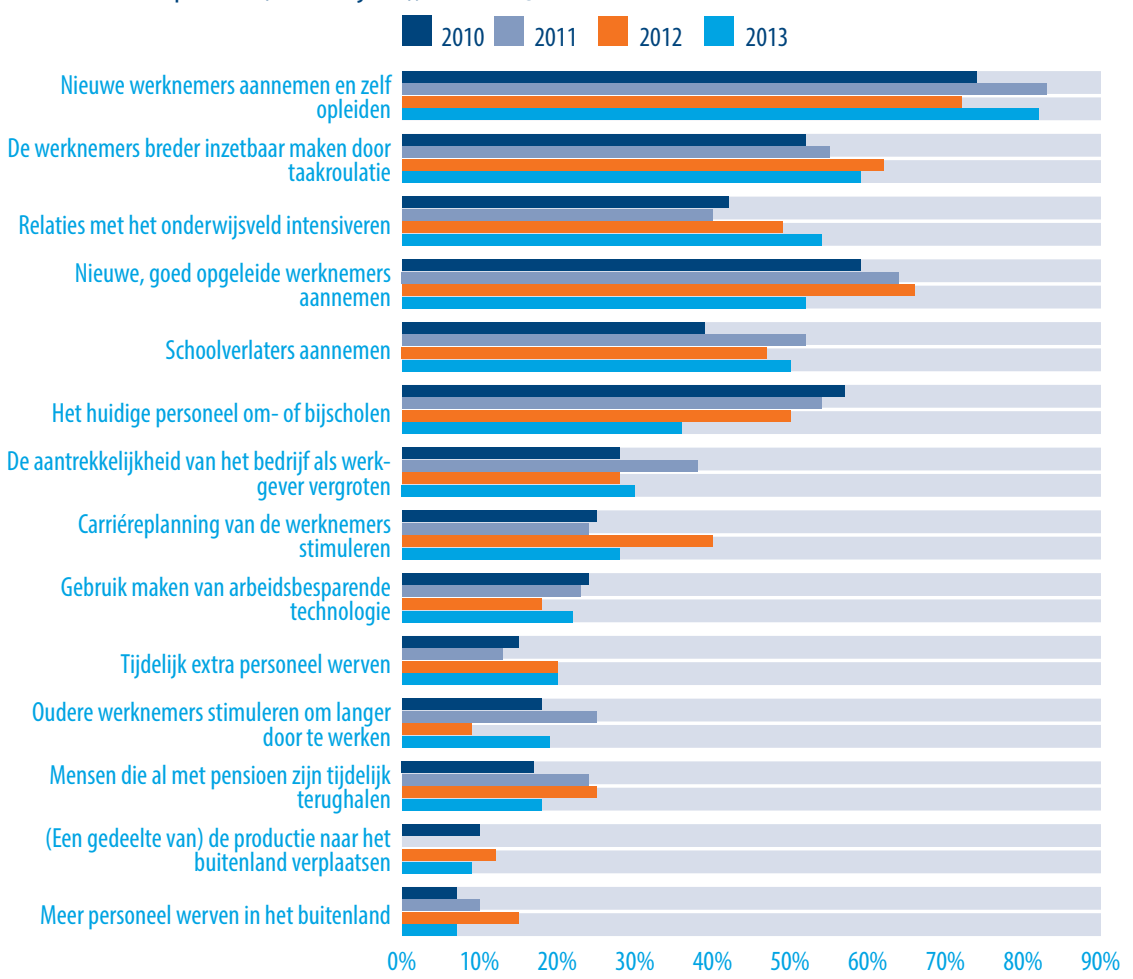

Bron: ROA, Arbeidsmarktmonitor Metalektro, 2010-2013

17 http://www.rijksoverheid.nl/documenten-en-publicaties/convenanten/2013/o5/13/nationaal-techniekpact-2020.html 


\section{7 \\ METALEKTRO \\ IN DE TOEKOMST}

De verwachtingen van bedrijven wijzen op een bescheiden werkgelegenheidsgroei in de eerste helft van 2014. De aanwas van nieuwe banen, gecombineerd met de op gang komende uitstroom van medewerkers die met pensioen gaan, veroorzaakt mogelijk knelpunten bij het vinden van geschikt personeel voor specifieke functies. Op basis van de ROA arbeidsmarktprognoses worden dergelijke knelpunten voornamelijk verwacht wanneer er wordt gezocht naar gediplomeerden van de opleidingsrichtingen $M B O$ werktuigbouw, MBO fijnmechanische techniek, HBO werktuigbouwkunde en elektrotechniek op alle opleidingsniveaus. De vraag naar medewerkers met deze opleidingsachtergrond zal voor een groot deel het gevolg zijn van het vrijkomen van bestaande arbeidsplaatsen (bijvoorbeeld door vertrek vanwege pensionering), maar ook van de verwachte groei van de werkgelegenheid. De verwachte instroom vanuit voor de Metalektro relevante opleidingen blijft relatief laag vergeleken bij de vraag, wat tot frictie leidt tussen vraag en aanbod.

Een ruime meerderheid van de bedrijven verwacht dat technische functies in de toekomst meer allround zullen worden. Geheel in lijn hiermee is de bevinding dat zeven op de tien bedrijven de inzetbaarheid van hun personeel willen bevorderen. Hieraan ligt mogelijk ten grondslag dat bedrijven in economisch roerige tijden zo veel mogelijk gebruik willen maken van het eigen personeel om eventuele schommelingen op te vangen. Een voorwaarde hiervoor is echter dat (huidige) medewerkers de gewenste flexibiliteit en inzetbaarheid hebben of kunnen ontwikkelen. In Hoofdstuk 5 werd geconstateerd dat bedrijven de inzetbaarheid van hun medewerkers - in het bijzonder van uitvoerende technici - als (ruim) voldoende beoordelen. 
Eind 2013 leek aan de dalende werkgelegenheid in de Metalektro heel voorzichtig een einde te komen (zie Hoofdstuk 1). In juli 2013 was er na een jaar van overwegend krimpende bedrijven weer een licht overwicht van metalektrobedrijven die een groeiende werkgelegenheid kenden. Sindsdien zijn de verwachtingen voor de toekomst verbeterd, waren deze licht positief voor het laatste kwartaal van 2013 en ook voor het eerste kwartaal van 2014. In dit hoofdstuk wordt dieper ingegaan op de werkgelegenheidsverwachtingen van metalektrobedrijven.

Figuur 7.1 toont de verwachte ontwikkelingen van vier indicatoren: het aantal vacatures, de in- en uitstroom en de totale werkgelegenheid. Voor alle vier indicatoren is het aandeel bedrijven dat géén verandering verwacht in de eerste helft van 2014 veruit het grootst. Daarnaast geldt voor alle indicatoren dat het aandeel bedrijven dat een toename verwacht groter is dan het aandeel bedrijven dat een afname verwacht. Bijna een kwart van de bedrijven in de Metalektro verwacht in de eerste helft van het jaar de werkgelegenheid en de instroom van personeel in haar bedrijf te zien toenemen. Toch verwacht nog steeds $6 \%$ van de bedrijven een krimpende werkgelegenheid in de eerste helft van 2014. Tegen het licht van voorgaande jaren zijn de verwachtingen desondanks (gematigd) positief. Een jaar geleden was het aandeel bedrijven dat werkgelegenheidskrimp verwachtte (17\%) nog aanzienlijk groter dan het aandeel bedrijven dat groei voorzag (12\%).

FIGUUR 7.1 Verwachte werkgelegenheidsontwikkeling tot en met juni 2014 (\% bedrijven)

Zal afnemen Zal gelijkblijven Zal toenemen

Aantal vacatures

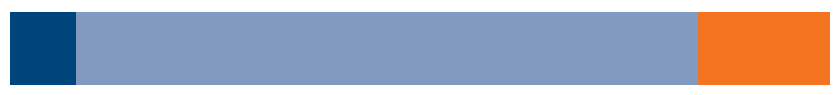

Totale werkgelegenheid

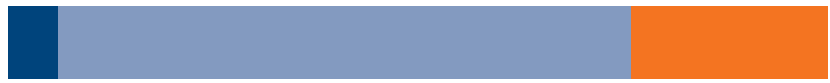

Instroom

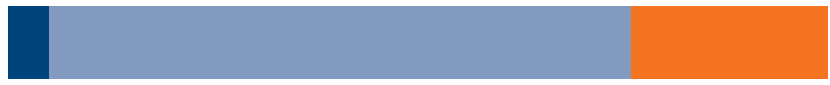

Uitstroom

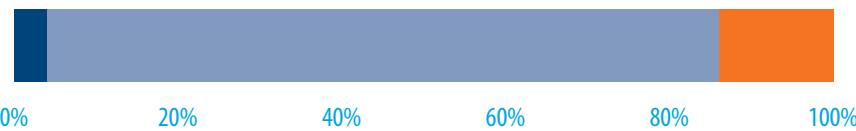

Bron: ROA, Arbeidsmarktmonitor Metalektro, 2013

De verwachtingen van de bedrijven wijzen dus in de richting van positieve werkgelegenheidsontwikkelingen voor de eerste helft van 2014. Dit zou echter een voorbarige conclusie zijn, omdat de gepresenteerde gegevens geen inzicht bieden in de omvang van de verwachte in- en uitstroom van werknemers. Wanneer het juist de grote metalektrobedrijven zijn die werkgelegenheidskrimp (meer uitstroom dan instroom) 
verwachten, zou dit voor de sector als geheel kunnen betekenen dat er per saldo meer mensen vertrekken dan er worden aangenomen. Om hierin meer inzicht te verkrijgen zijn in Figuur 7.2 de verwachte werkgelegenheidsontwikkelingen voor midden- en kleinbedrijven en grote bedrijven (250+ werknemers) afzonderlijk weergegeven.

FIGUUR 7.2 Verwachte werkgelegenheidsontwikkelingen naar bedrijfsgrootte tot en met juni 2014 (\% bedrijven)

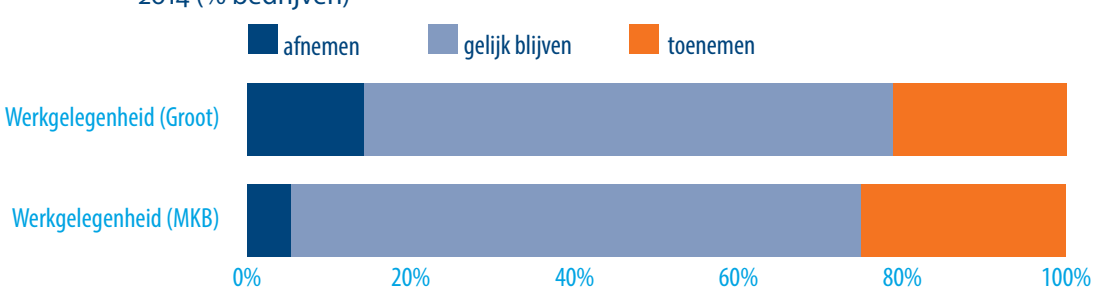

Bron: ROA, Arbeidsmarktmonitor Metalektro, 2013

Voor beide groepen geldt dat het aandeel dat groei noch krimp verwacht voor de eerste maanden van 2014 een ruime meerderheid vormt. Verder is het aandeel bedrijven dat groei verwacht zowel onder grote bedrijven als het MKB groter dan het aandeel dat verwacht te krimpen. In beide grootteklassen zijn dus meer bedrijven die groei dan krimp verwachten. Toch zijn er wel wat verschillen tussen het MKB en grote bedrijven te zien. Midden- en kleinbedrijven verwachten relatief iets vaker dan grote bedrijven een toename van de werkgelegenheid te verwachten. Bovendien voorzien grote bedrijven vaker dan MKB'ers een werkgelegenheidskrimp voor de komende maanden. ${ }^{8}$ Hoewel de groei zich naar verwachting meer laat zien binnen midden- en kleinbedrijven en de bedrijven die krimp voorzien voor het grootste deel tot de grootbedrijven behoren, blijft voor de sector in zijn geheel de conclusie uit deze verwachtingen dat er (per saldo) een lichte werkgelegenheidsgroei wordt verwacht.

\subsection{Knelpunten verwacht in de personeelsvoorziening tot 2018}

In de vorige paragraaf is vastgesteld dat bijna een kwart van de bedrijven verwacht dat de werkgelegenheid binnen het eigen bedrijf zal groeien in de eerste helft van 2014 . Het aandeel bedrijven dat verwacht problemen te ondervinden bij het vullen van baanopeningen is voor alle functiecategorieën echter flink gedaald ten opzichte van 2012. Bedrijven lijken zich minder zorgen te maken over het vinden van het juiste personeel. Het kan zijn dat zij verwachten zonder moeilijkheden nieuwe medewerkers te werven of de werkgelegenheidsgroei op een andere manier op te kunnen vangen. In deze paragraaf worden arbeidsmarktprognoses van ROA gepresenteerd, die betrekking hebben

18 Precies een jaar geleden was dit juist andersom: toen lag het aandeel bedrijven dat groei verwachtte nog significant hoger onder de grote bedrijven. 
op de vraag naar en het aanbod van arbeid voor verschillende technische functies. ${ }^{19}$ Uit de ROA arbeidsmarktprognoses voor de periode tot 2018 komt naar voren dat voor verschillende opleidingsrichtingen die van belang zijn voor de Metalektro, frictie wordt verwacht tussen de vraag naar medewerkers enerzijds en het aanbod van mensen met een passende opleidingsachtergrond anderzijds. Dit vertaalt zich in te verwachten knelpunten in de personeelsvoorziening van gerelateerde beroepen. Om meer inzicht te krijgen in de mate waarin er voor specifieke opleidingsrichtingen knelpunten worden voorzien, zijn in Tabel 7.1 verschillende cijfers gepresenteerd, waaronder de uitbreidingsvraag ${ }^{20}$, de vervangingsvraag ${ }^{21}$, de instroom vanuit de opleidingen ${ }^{22}$ en de Indicator Toekomstige Knelpunten Personeelsvoorziening (ITKP).

De uitbreidingsvraag is de vraag naar arbeid die ontstaat wanneer er sprake is van werkgelegenheidsgroei. Deze kan negatief zijn, wat duidt op krimpende werkgelegenheid. De vervangingsvraag is de vraag naar nieuwe arbeidskrachten als gevolg van het vrijkomen van bestaande arbeidsplaatsen door bijvoorbeeld pensionering, beroepenmobiliteit of uitstroom naar inactiviteit en arbeidsongeschiktheid. Indien de werkgelegenheid in een bepaalde opleiding of beroep niet krimpt, leidt vervangingsvraag tot vacatures die gevuld moeten worden. De ITKP geeft de verhouding weer tussen het arbeidsaanbod en de arbeidsvraag op de middellange termijn en toont derhalve in welke mate werkgevers voor de betreffende onderwijscategorie knelpunten bij de werving van personeel kunnen verwachten.

TABEL 7.1. Arbeidsmarktprognoses 2013-2018 voor verschillende opleidingsrichtingen

\begin{tabular}{|c|c|c|c|c|}
\hline & $\begin{array}{l}\text { Vervangings- } \\
\text { vraag* }\end{array}$ & $\begin{array}{l}\text { Uitbreidings- } \\
\text { vraag* }^{*}\end{array}$ & Instroom* & $\begin{array}{l}\text { ITKP - } \\
\text { typering }\end{array}$ \\
\hline VMBO metaal & 1,7 & 0,0 & 0,5 & Groot \\
\hline VMB0 elektrotechniek & 2,5 & $-0,1$ & 1,3 & Groot \\
\hline MBO werktuigbouw en mechanische techniek & 3,7 & 0,1 & 1,8 & Groot \\
\hline MBO fijnmechanische techniek & 4,8 & 0,0 & 2,5 & Groot \\
\hline MBO elektrotechniek & 3,0 & $-0,1$ & 2,4 & Groot \\
\hline MBO procestechniek & 2,9 & 1,7 & 5,8 & Vrijwel geen \\
\hline HBO werktuigbouwkunde & 4,2 & 0,5 & 2,5 & Groot \\
\hline HBO elektrotechniek & 2,8 & 0,1 & 2,1 & Groot \\
\hline Totaal (alle opleidingsrichtingen) $)^{23}$ & 2,8 & 0,0 & 3,4 & - \\
\hline
\end{tabular}

* Gemiddeld per jaar in procenten van de werkgelegenheid in 2012

Bron: ROA, Arbeidsmarktinformatiesysteem (AIS)

Zie voor een uitgebreide rapportage van de prognoses tot 2018 over de gehele breedte van de arbeidsmarkt: ROA (2013), De arbeidsmarkt naar opleiding en beroep tot 2018 (http://roa.nl/pdf_publications/2013/ ROA_R_2013_11.pdf). In percentages van de werkgelegenheid in 2012

Idem.

2 Idem.

23 Het betreft hier alle opleidingsrichtingen over de gehele breedte, dus ook de niet-technische opleidingsrichtingen. 
Voor zeven van de acht gepresenteerde opleidingsrichtingen geldt dat er naar verwachting tot 2018 knelpunten zullen ontstaan bij het vinden van personeel met de betreffende opleidingsachtergrond. Uitbreidingsvraag zal slechts een beperkte rol spelen in de totstandkoming van de vraag naar gediplomeerden van deze opleidingsrichtingen. Voor bijna alle opleidingsrichtingen - MBO procestechniek uitgezonderd - wordt namelijk (nagenoeg) geen uitbreidingsvraag verwacht. De vervangingsvraag ligt wél hoog voor verschillende opleidingstypen, met name in vergelijking tot de gemiddelde vervangingsvraag (2,8\%). Voor de opleidingen MBO werktuigbouw \& mechanische techniek, MBO fijnmechanische techniek en HBO werktuigbouwkunde geldt dat jaarlijks respectievelijk 3,7\%, 4,8\% en 4,2\% van het aantal werkenden in 2012 zal moeten worden vervangen. De baanopeningen die hier ontstaan zullen dan ook voornamelijk toe te schrijven zijn aan de behoefte aan vervanging van werknemers. Enkel voor banen die aansluiten bij de opleiding MBO procestechniek wordt een substantiële werkgelegenheidsgroei verwacht. Juist voor deze opleidingsrichting worden vrijwel geen knelpunten verwacht bij het vinden van geschikt personeel. De verwachte werkgelegenheidsgroei zal waarschijnlijk worden opgevangen door de eveneens hoge instroom van gediplomeerden uit deze opleidingen. Voor de overige opleidingen is de verwachte instroom op de arbeidsmarkt te laag om aan de verwachte vraag te kunnen voldoen. Deze knelpunten kunnen worden opgelost door bijvoorbeeld het verhogen van de instroom, het aantrekkelijker maken van banen in de techniek of door werving in het buitenland.

TEKSTBOX 7.1 Bij Toyota Material Handling wordt nu gewerkt aan de personeelsvoorziening voor de toekomst

Frans Kalkhoven, HR manager van Toyota Material Handling, geeft aan dat tijdig moet worden ingespeeld op eventuele tekorten aan personeel in de toekomst. Hoewel er momenteel geen sprake is van nijpende tekorten, moet hierover wel al worden nagedacht om de personeelsvoorziening voor de toekomst veilig te stellen. De heer Kalkhoven geeft aan dat dit op verschillende manieren kan. Eén van de oplossingen die hij aandraagt is het zelf opleiden van personeel. Toyota Material Handling is in 2012 gestart met het opleiden van leerlingen. Jaarlijks zijn dit inmiddels 5 à 6 leerlingen die een BBL traject volgen via een ROC of vakschool. Dat is al een verdrievoudiging ten opzichte van het aantal in 2012. Voordelen van BBL trajecten zijn dat mensen redelijk blanco binnen komen, je als bedrijf grip hebt op wat ze leren en het kennismakings- en selectieproces dus wederzijds van lange duur is. BBL'ers leren het bedrijf goed kennen en wij leren de mensen goed kennen. Hierdoor blijven enkel de krachten over met de beste 'fit' met de organisatie. 


\subsection{Technische functies zullen meer allround worden en gedragsmatige competenties worden belangrijker}

Op verschillende manieren maakten Metalektrobedrijven in 2013 ontwikkelingen door. Zo werden door het overgrote deel van bedrijven technologische ontwikkelingen doorgevoerd (Hoofdstuk 5), staan er verschillende organisatorische veranderingen op de agenda (Hoofdstuk 5) en zet de groei van het aandeel oudere werknemers in het personeelsbestand gestaag door (Hoofdstuk 6). In hoeverre deze veranderingen gevolgen hebben voor de functies van (technische) medewerkers wordt in deze paragraaf besproken. Aan bedrijven is gevraagd om aan te geven of ze de komende vijf jaar veranderingen verwachten in de functies van het technisch personeel en welke eventuele veranderingen dit zijn. In Figuur 7.3 zijn deze resultaten weergegeven.

Voor ruim één op de tien bedrijven geldt dat zich naar verwachting geen veranderingen zullen voordoen in de functies van het technisch personeel. De overige bedrijven verwachten in de komende jaren dus wel één of meerdere veranderingen in de functies van technici. De meest genoemde verandering is het meer allround worden van technische functies, wat door $63 \%$ van de bedrijven wordt verwacht. Dit is in lijn met een eerdere vaststelling dat steeds meer bedrijven werknemers naar andere functies in het bedrijf overplaatsten als gevolg van een krimpende werkgelegenheid (zie Hoofdstuk 2). Gedragsmatige competenties zullen belangrijker worden voor ruim de helft van de metalektrobedrijven. Andere veel voorkomende verwachtingen zijn dat technische functies op een lager niveau in de organisatie meer verantwoordelijkheden zullen hebben $(41 \%)$ en dat technische functies specialistischer worden (31\%).

FIGUUR 7.3 Verwachte veranderingen in de functies van het technisch personeel in de komende 5 jaar (\% bedrijven).

Er zullen zich geen veranderingen voordoen in de functies van het technisch personeel

Technische functies zullen meer allround worden

Gedragsmatige competenties worden belangrijker

Meer verantwoordelijkheden in de technische functies op een lager niveau in de organisatie

Technische functies zullen specialistischer worden

Minder verantwoordelijkheden in de technische functies op een lager niveau in de organisatie
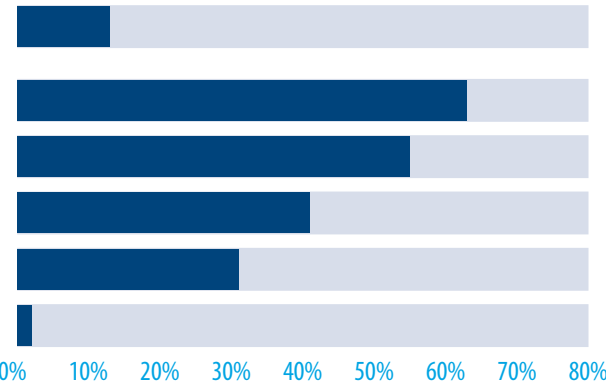

Bron: ROA, Arbeidsmarktmonitor Metalektro, 2010-2013 


\subsection{Bevorderen van inzetbaarheid is voor een ruime meerderheid van bedrijven een speerpunt}

Door de bedrijven is aangegeven wat de drie belangrijkste speerpunten van het personeelsbeleid voor de komende vijf jaar zijn. Figuur 7.4 toont de uitkomsten. Zoals in voorgaande jaren geeft een ruime meerderheid van bedrijven in de Metalektro - bijna $70 \%$ - aan dat het bevorderen van de inzetbaarheid van het personeel een speerpunt is van het personeelsbeleid. Hiermee is dit veruit het meest genoemde speerpunt voor de komende vijf jaar. De overige speerpunten zijn telkens door een minderheid van de bedrijven genoemd. Het bevorderen van coachend leiderschap vormt voor bijna een kwart van de bedrijven een speerpunt voor de komende jaren. Andere in de top vijf van meest genoemde speerpunten zijn het verminderen van verzuim, leeftijdsbewust personeelsbeleid en het intensiveren van de samenwerking met onderwijsinstellingen. Het aandeel bedrijven dat vermindering van verzuim tot de drie belangrijkste speerpunten rekent is bijna gehalveerd ten opzichte van vorig jaar. Deze daling zette in vanaf 2011 , toen nog $41 \%$ van de bedrijven het verminderen van verzuim als één van de belangrijkste speerpunten noemde. In 2013 bedraagt dit aandeel nog slechts 17\%. Wellicht dat door aanhoudende aandacht voor dit thema al dermate goede resultaten geboekt zijn in verzuimvermindering dat nu meer aandacht naar andere speerpunten uit kan gaan.

FIGUUR 7.4 Toekomstige speerpunten personeelsbeleid (\% bedrijven)

$$
\text { 2013-2017_2014-2018 }
$$

Bevorderen van de inzetbaarheid van het personee

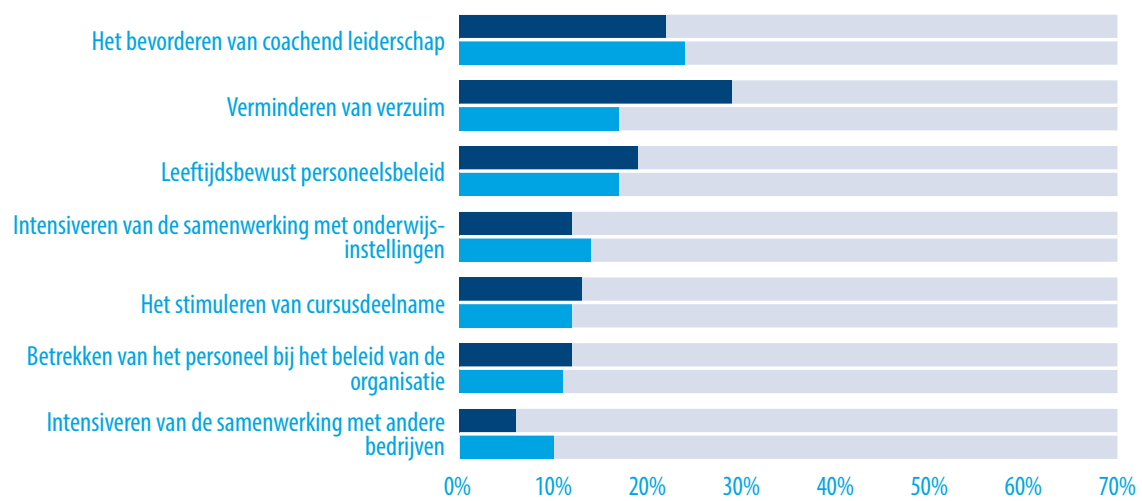

Bron: ROA, Arbeidsmarktmonitor Metalektro, 2012-2013

Noot: In de figuur zijn enkel de speerpunten opgenomen die voor tenminste één van de jaren door minimaal $10 \%$ van de bedrijven zijn genoemd. Speerpunten die door minder dan $10 \%$ genoemd werden zijn: verminderen van werkdruk, afstemming privé - werk verbeteren, voorkomen van vroegtijdige uitstroom, prestatiebeloning en/of flexibele beloning invoeren, flexibele werktijden invoeren, loopbaanbeleid implementeren en moderniseren van de arbeidsverhoudingen. 
Figuur 7.5 toont de HR instrumenten waarmee bedrijven de toekomstige speerpunten willen realiseren. Het meest populaire HR instrument dat wordt ingezet om de HR speerpunten te bereiken blijft - met een flinke afstand tot de overige instrumenten - het voeren van functioneringsgesprekken. Het aandeel bedrijven dat functioneringsgesprekken voert met haar personeel teneinde toekomstige speerpunten te realiseren is in de afgelopen jaren constant toegenomen van $53 \%$ in 2010 tot $72 \%$ in 2013 . Buiten deze stijging hebben zich in de afgelopen jaren weinig noemenswaardige veranderingen voorgedaan in de verwachte inzet van de verschillende instrumenten. De volgorde van meest gebruikte tot minst gebruikte HR maatregel - veranderde nauwelijks. Na de functioneringsgesprekken zijn het werkoverleg en de beoordelingsgesprekken nog steeds veel gebruikte instrumenten. Daarnaast maken ruim vier van de tien bedrijven gebruik van scholingsgesprekken en een bijna zo groot aandeel van een persoonlijk ontwikkelingsplan (POP). Een lichte stijging ten opzichte van voorgaande jaren is waar te nemen voor het bedrijfsopleidingsplan (BOP) en het bedrijfsopleidingsbudget. Het aandeel bedrijven dat deze instrumenten inzet is met respectievelijk 7 en 6 procentpunt gestegen. Dit wijst erop dat er naast ontwikkelingsafspraken met individuele medewerkers ook in toenemende mate voor het personeelsbestand als collectief aandacht wordt besteed aan scholingsafspraken.

Een van de weinige instrumenten die de afgelopen jaren minder wordt ingezet is loopbaanplanning. Het percentage bedrijven in de Metalektro dat aan loopbaanplanning doet om speerpunten te bereiken is gedaald van $20 \%$ in 2011 tot $9 \%$ in 2013 . Wellicht dat de afspraken die voorheen hierin gemaakt werden een plek hebben gekregen in andere instrumenten zoals de functioneringsgesprekken.

FIGUUR 7.5 HR Instrumenten t.b.v. het bereiken van toekomstige speerpunten (\% bedrijven)

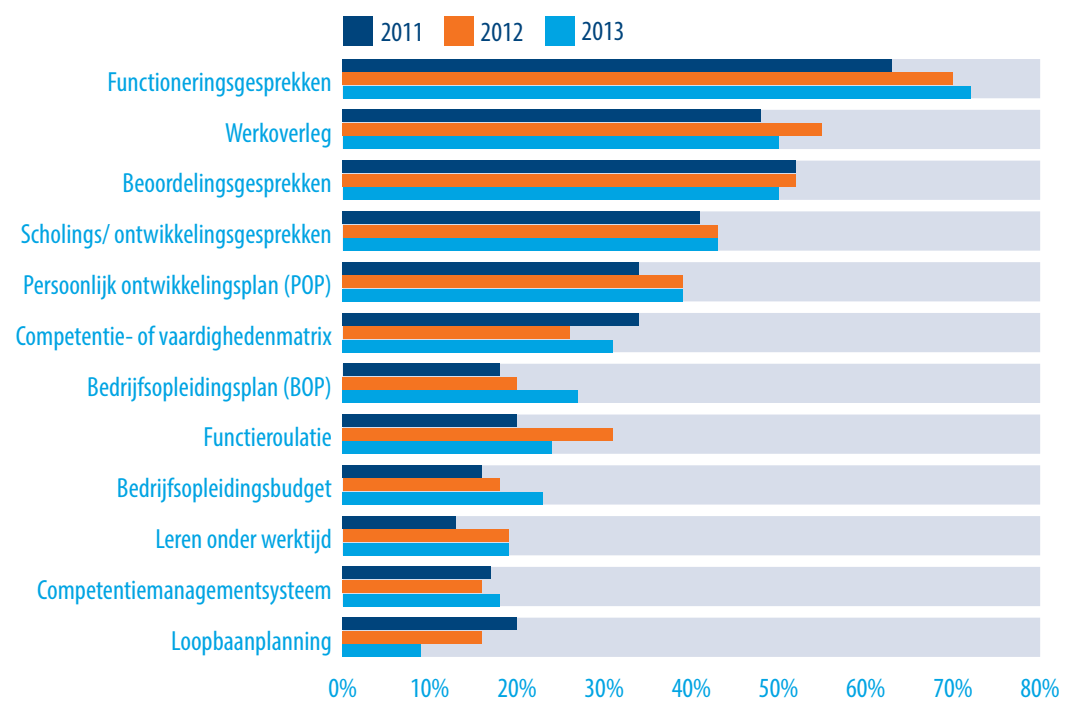

Bron: ROA, Arbeidsmarktmonitor Metalektro, 2011-2013

Noot: In de figuur zijn enkel de instrumenten opgenomen die voor tenminste één van de jaren door tenminste 10 procent van de bedrijven zijn genoemd. 


\subsection{Verwachte knelpunten bij de realisatie van speerpunten hebben voornamelijk betrekking op personeel}

In vergelijking met voorgaande jaren verwachten duidelijk meer bedrijven problemen bij het realiseren van hun speerpunten (zie Figuur 7.6). Het percentage bedrijven dat geen problemen verwacht bedroeg in 2011 nog $35 \%$ en daalde vervolgens tot $33 \%$ in 2012 en 26\% in 2013. Met andere woorden, bijna driekwart van de bedrijven verwacht problemen bij het realiseren van de speerpunten van hun personeelsbeleid. Er worden vooral problemen voorzien bij de omgang van het personeel met veranderingen. $42 \%$ van de bedrijven noemde dit als een te verwachten knelpunt, dit is een stijging van 10 procentpunt ten opzichte van het voorgaande jaar. Voorts verwachten metalektrobedrijven dat de flexibiliteit van het personeel tekortschiet (22\%), het personeel een te laag kennisniveau heeft (21\%) en het personeel onvoldoende bereid is om in zichzelf te investeren (20\%). Vergeleken met de knelpunten die op het personeel betrekking hebben, worden knelpunten op organisatorisch niveau - zoals onvoldoende financiële middelen, onvoldoende zicht op de competenties van het personeel en onvoldoende medewerking van de direct leidinggevende - door de bedrijven minder vaak verwacht.

FIGUUR 7.6 Verwachte knelpunten bij het realiseren van toekomstige speerpunten (\% bedrijven)

$$
\text { 2013-2017 2014-2018 }
$$

Er worden geen knelpunten verwacht

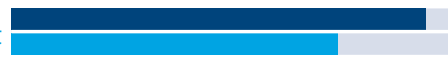

Personeel kan moeilijk omgaan met veranderingen

Flexibiliteit van personeel schiet tekort

Personeel heeft een te laag kennisniveau

Personeel onvoldoende bereid om in zichzelf te investeren

Onvoldoende budget beschikbaar

Personeel onvoldoende gemotiveerd om mee te gaan met veranderingen

Onvoldoende zicht op competenties personeel

Onvoldoende medewerking van direct leidinggevende

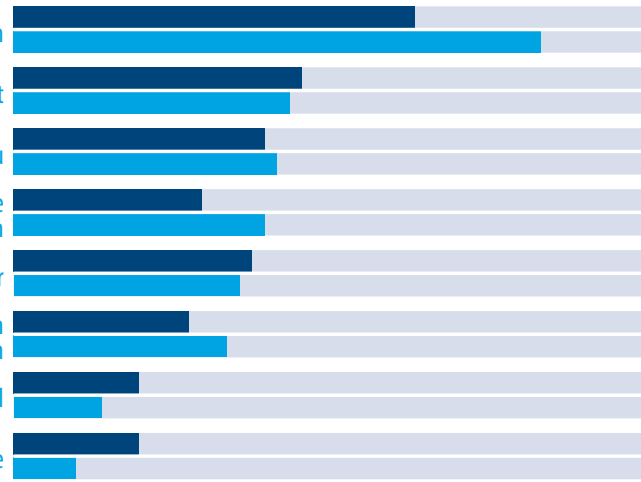

$\begin{array}{lllllllllll}0 \% & 5 \% & 10 \% & 15 \% & 20 \% & 25 \% & 30 \% & 35 \% & 40 \% & 45 \% & 50 \%\end{array}$

Bron: ROA, Arbeidsmarktmonitor Metalektro, 2012-2013

Noot: In de figuur zijn enkel de knelpunten opgenomen die voor tenminste één van de jaren door tenminste 10 procent van de bedrijven zullen worden ingezet met als doel de toekomstige speerpunten te bereiken. 



\section{8 AGENDA VOOR DE TOEKOMST}

Diverse indicatoren in de Metalektro zoals de omzet, de omvang van de flexibele schil, het aantal bedrijven met vacatures en de gemiddelde training- en cursusdeelname ontwikkelden zich in 2013 in opwaartse richting. Voor de komende jaren hebben metalektrobedrijven ook optimistische verwachtingen voor de werkgelegenheidsontwikkeling en flinke ambities op het terrein van innovatie en het aangaan van samenwerkingsverbanden. Bij het realiseren van deze ambities en verwachtingen kunnen bedrijven terugvallen op de $H R$ strategieën die in de afgelopen jaren zijn ingezet. De bedrijven hoeven op HR gebied dus niet het wiel opnieuw uit te vinden, maar men moet scherp blijven op de bekende knelpunten, die de komende jaren onverminderd actueel blijven. Belangrijk knelpunt blijft de voortschrijdende vergrijzing van het personeelsbestand van veel bedrijven en het daaraan gerelateerde vervangingsvraagstuk. Metalektrobedrijven verwachten over het algemeen geen grote vervangingsproblemen. Wanneer de arbeidsmarktuitstroom vanwege pensionering over enkele jaren in een versnelling raakt en op dat moment de economie weer beter draait, dan zullen de vervangingsproblemen echter groot zijn. Het aantal moeilijk vervulbare vacatures zal dan weer toenemen. Veel bedrijven proberen de gevolgen van moeilijk vervulbare vacatures te ondervangen door hun personeel te laten overwerken. Op de lange termijn is dit niet zonder gevaar voor de duurzame inzetbaarheid van medewerkers. Het blijft daarom voor de bedrijven van groot belang om de ontwikkelingen op de arbeidsmarkt te blijven volgen en eventuele tekenen van toenemende krapte voor bepaalde functies meteen in een langetermijn perspectief te plaatsen. Daarbij zullen de bedrijven de aandacht voor de toekomstige vervangingsvraag goed vast dienen te houden en zullen ze nog scherper moeten zijn op de mogelijke gevolgen van moeilijk vervulbare vacatures voor de duurzame inzetbaarheid van hun medewerkers. 


\subsection{Achtergrond}

Een drietal lange termijn trends vormt al jaren de rode draad van de arbeidsmarktontwikkelingen in de Metalektro: een dalende werkgelegenheid (Figuur 1.4), een stijgende gemiddelde leeftijd (Figuur 1.5) en een stijgend gemiddeld opleidingsniveau (upgrading) in de sector (Figuur 1.6). Ook in 2013 hebben deze trends zich doorgezet. Daarnaast zijn er ontwikkelingen die continu in beweging zijn, al dan niet gerelateerd aan de omzetontwikkeling in de sector. In de afgelopen jaren stonden veel ontwikkelingen in de Metalektro dan ook in het licht van de economische crisis en het effect van deze crisis op de omzet. In de Agenda voor de Toekomst van vorig jaar constateerden we dat er in veel bedrijven consolidatie op kernactiviteiten rondom een kern van vaste medewerkers heeft plaatsgevonden. Ondanks een werkgelegenheidsdaling voor de sector als geheel, was er voor uitvoerende en leidinggevende technici en engineering en R\&D functies in de tweede helft van 2012 een groei in de werkgelegenheid. De focus op een kern van vaste medewerkers uitte zich ook in een gestegen vraag naar breed inzetbare medewerkers die de aanzet gaf tot diverse HR maatregelen en organisatorische veranderingen.

Waar 2012 een bijzonder zwaar jaar was voor de sector met vier kwartalen omzetdaling, kende 2013 daarentegen een aanmerkelijk positiever omzetverloop. De omzet kroop uit het dal, wat in de tweede helft van het jaar weer leidde tot omzetgroei (Figuur 1.2). In 2013 hebben de drie hierboven genoemde lange-termijn trends zich doorgezet, maar is er in het kielzog van de positieve omzetontwikkeling een omslag in positieve richting gekomen in veel andere indicatoren. Hierbij lijkt het er voorzichtig op dat deze positieve ontwikkelingen niet slechts een tijdelijke opleving in de tweede helft van 2013 zijn, maar een langere adem hebben. Om een blik op de toekomst te werpen vatten we daarom in deze Agenda voor de Toekomst de omslag in de omzetontwikkeling en in diverse andere indicatoren samen. De recente ontwikkelingen worden in paragraaf 8.2 geschetst. Paragraaf 8.3 gaat in op de toekomstverwachtingen van metalektrobedrijven en paragraaf 8.4 besteedt aandacht aan de vergrijzing en verwachte vervangingsproblemen. Paragraaf 8.5 vat de belangrijkste conclusies samen.

\subsection{Door de bank genomen positieve ontwikkelingen in 2013}

\section{Blijvende consolidatie van kernactiviteiten, daaromheen een groeiende flexibele schil}

Hoewel ook in 2013 de werkgelegenheid in de sector afnam, stabiliseerde deze afname zich in de tweede helft van het jaar. In de eerste helft van 2013 was de personeelsuitstroom nog groter dan de instroom, maar in de tweede helft van het jaar waren instroom en uitstroom nagenoeg in balans (Figuur 2.4). Daarbij valt op dat er, in lijn met de consolidatie rondom de kernactiviteiten, groei plaatsvond in de omvang van het engineering en R\&D personeel en er relatief weinig krimp was bij uitvoerende technici. Daarentegen zagen we in 2013 de sterkste afname in de werkgelegenheid bij de ondersteunende functies en de leidinggevende niet-technische functies. Deze functies zijn minder essen- 
tieel voor de kernactiviteiten productie en ontwikkeling, terwijl uitvoerende technici en engineers dat wel zijn. De consolidatie rondom de kernactiviteiten lijkt zich dus ook in 2013 te hebben doorgezet. Een groot verschil met 2012 is echter de positieve omzetontwikkeling in 2013, wat zich onder meer aftekent in een daling van het aantal bedrijven dat vanwege onvoldoende vraag productiebelemmeringen ondervindt.

Tegelijkertijd zien we dat de flexibele schil in 2013 sterk is uitgebreid om in deze conjuncturele opleving mee te kunnen bewegen. Mocht het economisch tij onverhoopt weer tegen zitten, dan hoeft alleen de flexibele schil verkleind te worden en blijft de vaste kern intact. Een interessante ontwikkeling is wel dat de flexibele schil voor een groot deel is gegroeid met medewerkers met tijdelijke contracten, terwijl in het verleden vaker voor ingeleende krachten werd gekozen (paragraaf 2.4). Enerzijds zijn bedrijven in de Metalektro in 2013 dus nog voorzichtig geweest door op de conjuncturele opleving te reageren met het aantrekken van flexibele krachten, anderzijds toont de keuze om met name voor tijdelijke contracten te kiezen een teken van vertrouwen in de toekomst. Een tijdelijk contract is immers een dienstverband bij het bedrijf zelf, wat gezien kan worden als een positieve intentie om bij aanhoudende economische voorspoed en goed functioneren van de medewerker tot een vast dienstverband over te gaan. Van het inhuren van uitzendkrachten gaat deze intentie een stuk minder sterk uit. ${ }^{24}$

\section{Meer bedrijven met vacatures en minder wervingsproblemen}

Een verdere bevestiging van de conjuncturele opleving is af te leiden uit het gestegen percentage bedrijven met vacatures (Hoofdstuk 3), die bovendien vaker dan voorheen het gevolg waren van een toename van het werk (Figuur 3.3). Ondanks een toename van het aantal bedrijven met vacatures, zien we sinds 2008 een daling van het percentage bedrijven dat problemen ondervindt bij het werven van technici (Figuren 3.8 en 3.9). Ook nam het aandeel van de vacatures dat erg lang open stond af (Figuur 3.2). Het is te gemakkelijk om de afname van de wervingsproblemen enkel op het conto van de economische crisis, de verminderde vraag naar arbeid en de toenemende werkloosheid te schuiven. Natuurlijk maakt de hoge werkloosheid, die momenteel veel meer is dan alleen een 'granieten laag', dat de arbeidsmarkt veel ruimer is dan voorheen. Dit neemt niet weg dat diverse inspanningen van individuele metalektrobedrijven, samenwerkingsverbanden binnen de sector en tussen sectoren, sociale partners in de technische sectoren en de overheid, er waarschijnlijk allemaal aan hebben bijgedragen dat de wervingsproblemen voor technische functies zijn verminderd.

Hoewel voor bepaalde metalektrobedrijven het inschakelen van externe bureaus nog altijd belangrijk is, is dit voor de meeste bedrijven niet meer de meest gehanteerde strategie om moeilijk vervulbare vacatures te lijf te gaan. Flink gestegen in populariteit - en nipt op de eerste plaats als wervingsstrategie in 2013 - is de keuze van bedrijven om

24 Givord, P. and Wilner, L. (2014), When does the stepping stone work? Fixed-term contracts versus temporary agency work in changing economic conditions. Journal of Applied Econometrics. doi: 10.1002/jae.2394 
goede loopbaanperspectieven te bieden. Dit maakt het aantrekkelijker voor technisch opgeleiden om na hun afstuderen ook in de techniek aan de slag te gaan, waardoor de weglek van technici naar andere sectoren vermindert. Daarnaast bereikten begin 2014 de eerste signalen de media dat de animo voor technische opleidingen in de lift zit. Landelijke initiatieven zoals het TechniekPact en TechniekTalent.nu en "Triple Helix" samenwerkingen tussen diverse sectororganisaties, bedrijven, onderwijsinstellingen en lokale overheden, zoals in de TechniekCampus Zaanstreek (zie Tekstbox 5.4) dragen waarschijnlijk ook bij aan het verminderen van wervingsproblemen, zowel door het verminderen van de weglek van schoolverlaters die op de arbeidsmarkt instromen (korte-termijn effect) als op de middellange- en lange termijn door een stijging van de instroom in het technisch onderwijs.

Huidige wervingsproblemen betreffen vooral uitvoerende technici en engineers/R\&D functies

Ondanks de positieve vruchten die alle inspanningen op bedrijfs- , sector en macro niveau lijken af te werpen zijn er echter nog steeds wervingsproblemen, met bijkomende gevolgen, die als de economie blijft aantrekken eerder erger dan minder zullen worden. Vooral uitvoerende technici en engineering en R\&D personeel zijn het moeilijkst vindbaar. Ook uit de arbeidsmarktprognoses van het ROA, opgenomen in Tabel 7.1 van dit rapport, blijkt dat er voor een aantal specifieke opleidingsrichtingen de komende jaren knelpunten worden verwacht. Wat bijzonder zorgwekkend is, is dat moeilijk vervulbare vacatures volgens de bedrijven in toenemende mate leiden tot minder mogelijkheden om te innoveren (Tabel 3.1). Hoewel dit niet het meest voorkomende gevolg is van het niet kunnen invullen van vacatures, is dit in 2013 voor het eerst op een vierde plaats binnen gekomen in de top 5 . Bijna een derde van de bedrijven geeft aan dat dit een van de gevolgen is van niet-ingevulde vacatures. Anderzijds tekent dit echter ook het huidige hoge ambitieniveau van deze bedrijven ten aanzien van hun huidige en toekomstige innovatieplannen. In paragraaf 8.3 gaan we kort in op deze innovatieplannen.

Naast de negatieve effecten op het innovatievermogen blijft het een zorgpunt dat'overwerk' één van de meeste toegepaste interne aanpassingen is gebleven om de gevolgen van onvervulde vacatures te ondervangen (Figuur 3.13). Gecombineerd met de beperkte aandacht voor de HR speerpunten 'privé - werk balans' en 'werkdruk verminderen' (Figuur 7.4) kan dit op de lange termijn negatieve gevolgen hebben voor de duurzame inzetbaarheid van mensen, zoals ook beschreven in de Agenda voor de Toekomst van vorig jaar. Waakzaamheid blijft op dit punt dus geboden, temeer bij een aantrekkende economie. 

neel

Na jaren van daling zijn de gemiddelde scholingsbestedingen van metalektrobedrijven in 2013 niet verder gedaald (Figuur 4.1). Met gemiddelde uitgaven aan directe kosten voor trainingen en cursussen van 1,3\% van de loonsom in 2012 en 2013 lijkt de bodem bereikt en is de daling, die de laatste jaren al afvlakte, definitief gestopt. Daarnaast nam de gemiddelde training- en cursusdeelname toe voor zowel vaste, tijdelijke als ingeleende krachten, hoewel dit opmerkelijk genoeg vooral bij de tijdelijke en ingeleende krachten het geval was. Naast de traditioneel grote aandacht voor de vaktechnische ontwikkeling van de medewerkers werd er in 2013 weer meer aandacht besteed aan de ontwikkeling van medewerkers op het gebied van onder meer taalvaardigheden, commerciële vaardigheden en plannen en organiseren. Daarnaast verwachten de bedrijven dat er de komende jaren meer cursussen gevolgd zullen worden op de gebieden van leidinggeven, veilig gedrag, communicatie- en commerciële vaardigheden. Ook wanneer wordt gevraagd naar toekomstige veranderingen in technische functies geeft een meerderheid van de bedrijven aan dat technische functies meer allround zullen worden en gedragsmatige competenties belangrijker worden (Figuur 7.3). Dit bevestigt de blijvend grote behoefte aan breed inzetbare werknemers en het toenemende belang van de PROFI competenties:

- Probleemoplossend vermogen

- Relatie met klanten

- Omgaan met veranderingen

- Flexibiliteit

- Initiatief

De onverminderd grote behoefte aan breed inzetbaar personeel blijkt ook als bedrijven hier direct naar gevraagd wordt (Figuur 5.6). In de Agenda voor de Toekomst van vorig jaar was dit ook al een belangrijke constatering, samen met de consolidatie op kernactiviteiten en een vaste kern van medewerkers. Waar echter in 2012 nog voor diverse functiecategorieën, waaronder uitvoerende technici en engineering en R\&D personeel, een tekort aan breed inzetbare werknemers werd ervaren is deze situatie in 2013 sterk verbeterd.

\subsection{Positieve verwachtingen voor diverse indicatoren tekenen gestegen vertrouwen}

Naast de positieve ontwikkeling van de omzet, de groei van de flexibele schil (met in eerste instantie veel tijdelijke contracten) en het vertrouwen dat daaruit opgemaakt kan worden, zien we dit gestegen vertrouwen ook rechtstreeks terug in de toekomstverwachtingen die de metalektrobedrijven via de vragenlijsten van de Arbeidsmarktmonitor hebben uitgesproken. Gemiddeld genomen verwachten metalektrobedrijven in de (nabije) toekomst onder meer een: 
- toename van werkgelegenheid (Figuren 1.3, 7.1 en 7.2)

- toename van innovatie op alle terreinen (Figuren 1.8 en 5.1)

- toename van organisatorische veranderingen (Figuur 5.2)

- toename van samenwerking binnen de keten/met klanten en binnen de sector (Figuur 5.11)

- toename van samenwerking met hogescholen/universiteiten en andere onderwijsinstellingen (Figuur 5.11)

$\mathrm{Na}$ jaren waarin de werkgelegenheid in de sector kromp, is het belangrijk dat er nu meer bedrijven zijn die een groei van de werkgelegenheid in hun bedrijf verwachten dan bedrijven die krimp verwachten. Dit geldt zowel voor het MKB als voor de grote bedrijven. Daarnaast verwachten bedrijven op alle vlakken, van product tot proces tot dienstverlening, meer te gaan innoveren. Wellicht gerelateerd aan deze innovatie ambitie is de weer sterker naar buiten gerichte blik die tot uiting komt in verwachte toename van de samenwerking met diverse externe partijen. Zo is het percentage bedrijven dat verwacht in de komende vijf jaar met hogescholen/universiteiten te gaan samenwerken gestegen van 30\% naar 50\%. Ook met andere onderwijsinstellingen zal de samenwerking toenemen. Bovendien wordt er meer samenwerking verwacht met andere bedrijven, zowel binnen de keten/met klanten als binnen de sector. Ook de ambities van bedrijven voor andere typen organisatorische verandering zitten in de lift.

\subsection{Vergrijzing en verwachte vervangingsproblemen}

Zoals Figuur 1.5 laat zien stijgt de gemiddelde leeftijd in de Metalektro al jaren en is het percentage werkende 50-plussers in de sector sinds 2011 hoger dan het landelijke gemiddelde over alle sectoren van de economie. Desondanks daalt het door metalektrobedrijven gemiddeld verwachte percentage medewerkers dat met pensioen gaat al jaren (Figuur 6.4) en daalt ook het percentage bedrijven dat veel vervangingsproblemen verwacht door pensionering (Figuur 6.5). Ongetwijfeld speelt de stijging van de pensioenleeftijd die de afgelopen jaren heeft plaatsgevonden hier een belangrijke rol. Daarbij wordt waarschijnlijk onvoldoende beseft dat dit de vervangingsproblematiek niet oplost, maar slechts vooruit schuift tot op het moment dat de gemiddelde pensioneringsleeftijd niet verder stijgt. Aangenomen mag worden dat dit over enkele jaren het geval zal zijn. Los daarvan kan de pensioenleeftijd wel stijgen op papier, maar in fysiek zwaardere functies is langer doorwerken niet altijd een optie. Hierdoor zullen bedrijven steeds meer te kampen krijgen met oudere medewerkers die onvoldoende inzetbaar zijn. Deze beperkte inzetbaarheid kan worden verbeterd als er bij het bedrijf en/of de medewerkers zelf voldoende aandacht is voor het up-to-date houden van competenties en het bewaken van de fysieke belasting en gezondheid. Gezien de grote aandacht die veel bedrijven hebben voor product-, proces en diensteninnovaties zal het van groot belang zijn om in de oudere medewerkers te blijven investeren. 
Het is de vraag of metalektrobedrijven niet onderschatten welke vervangingsproblematiek er op hen af komt, of dat ze zo weinig problemen verwachten omdat ze er steeds beter op voorbereid zijn. In Hoofdstuk 6 van dit rapport is uitgebreid besproken welke maatregelen bedrijven in de Metalektro nemen om de vervangingsproblemen te ondervangen. Hieruit blijkt dat een meerderheid van de bedrijven een of meerdere Active-Ageing instrumenten inzet om hun medewerkers te faciliteren en dat bedrijven ook in grote getale HR maatregelen nemen specifiek met het oog op de vervanging van medewerkers die met pensioen gaan. De meest populaire Active-Ageing instrumenten zijn het breed inzetbaar maken van medewerkers, aandacht voor de fysieke belasting en rekening houden met de leeftijdsopbouw binnen het bedrijf. De meest populaire HR maatregelen om de vervangingsvraag op te vangen is het aannemen van nieuwe medewerkers en deze zelf opleiden. Het lijkt er dan ook op dat metalektrobedrijven zich terdege bewust zijn van de problematiek en actief bezig zijn met maatregelen op diverse vlakken. De afgelopen jaren hebben echter in het teken van economische crisis gestaan en het is nu de vraag of de positieve verwachtingen van bedrijven over hun vervangingsproblematiek nog steeds gerechtvaardigd blijken te zijn als het economisch herstel de komende jaren serieus doorzet en sommige oudere medewerkers toch niet zo lang blijken te kunnen doorwerken als nu misschien wordt gedacht. Op basis van de ROA arbeidsmarktprognoses worden er voor de komende jaren voornamelijk wervingsproblemen verwacht wanneer er wordt gezocht naar gediplomeerden van de opleidingsrichtingen MBO werktuigbouw, MBO fijnmechanische techniek, HBO werktuigbouwkunde en elektrotechniek op alle opleidingsniveaus. Het is daarom voor metalektrobedrijven van groot belang om de ontwikkelingen op de arbeidsmarkt alert te blijven volgen en eventuele tekenen van toenemende krapte voor bepaalde functies meteen in een langer-termijn perspectief te plaatsen.

\subsection{Concluderend: positieve tekenen maar scherpte op knelpunten blijft geboden}

De positieve economische ontwikkelingen die sinds 2013 weer zichtbaar zijn hebben de sector een impuls van optimisme en ambitie gegeven. Verwachtingen ten aanzien van de werkgelegenheid, innovatie en samenwerkingsverbanden zijn optimistisch en tonen bij veel bedrijven een grote ambitie. De komende jaren zullen in het teken staan van het realiseren van deze ambities. Daarbij zijn de HR strategieën die in de afgelopen jaren zijn ingezet, maar óók de knelpunten die al langer bekend zijn, beide onverminderd actueel. De bedrijven hoeven op HR gebied dus niet het wiel opnieuw uit te vinden, maar men moet scherp blijven op de bekende knelpunten. Zo zijn bedrijven in 2013 een stuk meer tevreden met het aanbod van breed inzetbare medewerkers in hun bedrijf en hebben de HR inspanningen op dat terrein dus al het beoogde effect gehad, al blijft de vraag naar breed inzetbaar personeel ("het schaap met de vijf poten") erg hoog. De scherpte van de bedrijven blijft in het bijzonder vereist ten aanzien van de knelpunten die door de ruime arbeidsmarkt vanwege de economische crisis tijdelijk iets minder voelbaar waren, maar die door een verder aantrekkende economie snel aangewakkerd kunnen worden. Denk hierbij aan de mogelijke onderschatting van de vervangingsvraag en de popu- 
laire maatregel om moeilijk vervulbare vacatures op te lossen door middel van overwerken, wat qua werkdruk en gezondheid zijn grenzen kent. Beide knelpunten zullen bij een aantrekkende economie sterker tot uiting komen en lange-termijn consequenties hebben, waarvoor bedrijven voldoende oog moeten hebben. Tot slot zal het realiseren van alle in 2013 door de metalektrobedrijven uitgesproken verwachtingen en ambities ook afhangen van de vraag of de Nederlandse economie de export-gedreven wind in de zeilen weet te houden en in het kielzog daarvan het consumentenvertrouwen nog verder gaat aantrekken. 